João Arthur Basile Macieira

\title{
ERNEST HEMINGWAY ENTRE A LITERATURA E A
} HISTÓRIA

Dissertação de Mestrado

Dissertação apresentada ao programa de Pós-Graduação em História Social da Cultura como requisito parcial para obtenção do grau de Mestre em História.

Orientador: Marcelo Gantus Jasmin

Rio de Janeiro Fevereiro de 2021 


\title{
Pontifícia Universidade C $_{\text {atólica }}$

João Arthur Basile Macieira

\section{ERNEST HEMINGWAY ENTRE A LITERATURA E A HISTÓRIA}

\begin{abstract}
Dissertação de Mestrado
Dissertação apresentada ao programa de Pós-Graduação em História Social da Cultura como requisito parcial para obtenção do grau de Mestre em História. Aprovada pela

Comissão Examinadora abaixo:
\end{abstract}

Prof. Marcelo Gantus Jasmin Orientador

Departamento de História (PUC-Rio)

Prof. Henrique Estrada Rodrigues

Departamento de História (PUC-Rio)

Profa. Luiza Langueira Departamento de História Social (UFRJ)

Rio de Janeiro

Fevereiro de 2021 
Todos os direitos reservados. É proibida a reprodução total ou parcial do trabalho sem a autorização da universidade, do autor e do orientador.

\section{João Arthur Basile Macieira}

Graduou-se em Ciências Sociais pela Universidade Federal do

Estado do Rio de Janeiro. Tem interesse em Teoria Historiográfica, Teoria Social e Literatura. Ingressou na PUCRio em 2019 como mestrando em História Social da Cultura.

Ficha Catalográfica

Macieira, João Arthur Basile

Ernest Hemingway entre a literatura e a história / João Arthur Basile Macieira ; orientador: Marcelo Gantus Jasmin. $-2021$.

100 f. ; $30 \mathrm{~cm}$

Dissertação (mestrado)-Pontifícia Universidade Católica do Rio de Janeiro, Departamento de História, 2021.

Inclui bibliografia

1. História - Teses. 2. História Social da Cultura - Teses. 3. Historiografia. 4. Teoria crítica. 5. Século XX. 6. Superficialidade. 7. Fragmentação. I. Jasmin, Marcelo Gantus. II. Pontifícia Universidade Católica do Rio de Janeiro. Departamento de História. III. Título. 
Uma dissertação de mestrado não é trabalho que se faça sozinho, por mais que sua escritura seja, em grande parte, a duas mãos. Portanto, qualquer lista de agradecimentos seria insuficiente, uma vez que não foram apenas os cursos tomados durante o mestrado ou as horas dedicadas à pesquisa empírica que deram fruto ao texto que se segue, mas um longo percurso (ainda inacabado) de formação e aprendizado, no qual são atores não apenas professores, mas também os amigos que fazemos, os romances e poesias que lemos, os filmes que assistimos, os jogos que jogamos, as cidades que visitamos... a lista continuaria ao infinito. O que importa é que esta dissertação excede seu autor, pois é fruto de fluxos que vão muito além dele. $\mathrm{O}$ que não lhe retira a responsabilidade diante dos erros que o leitor há de encontrar no texto.

Dedico esta dissertação a minhã mãe, Heloisa. 


\section{Agradecimentos}

Agradeço ao meu orientador Marcelo Jasmin, que deu toda a liberdade para que o texto seguisse as próprias direções;

Agradeço ao CNPq e à CAPES pela bolsa concedida, sem a qual essa pesquisa seria impossível;

Aos meus amigos de Petrópolis: Mario, Luís, Flávio, João Lucas, Pietro e Gabriel, que nunca deixaram a distância nos distanciar;

Ao meu amigo de Unirio, Carlos Henrique, cuja força é inspiradora a qualquer moemento;

A minha irmã Lívia, com quem foi possível discutir o texto em momentos e direções tão distintos;

Ao meu amigo Pedro Fraga;

À Juliana, que me acompanhou durante todo o processo de construção desse texto;

A Cláudia Mazollilo, pela revisão deste texto;

Ao corpo docente e funcionários do Programa de História da PUC; especialmente aos professores Henrique Estrada e Diego Galeano, cujas leituras durante a fase de qualificação foram fundamentais;

Por fim, agradeço aos meus pais, que mais uma vez fizeram todos os esforços para que isso fosse possível. 


\section{Resumo:}

Macieira, João Arthur; Jasmin, Marcelo Gantus. Ernest Hemingway entre a literatura e a história. Rio de Janeiro, 2021. 100 p. Dissertação de Mestrado - Departamento de História, Pontifícia Universidade Católica do Rio de Janeiro.

Esta dissertação investiga as relações entre Literatura e História, assim como aparecem na obra de Ernest Hemingway. Aqui, buscamos dialogar com algumas das principais correntes do pensamento historiográfico, assim como da crítica literária, a fim de apontar algumas especificidades na produção desse autor. Menos um capítulo de História da Literatura, o texto a seguir buscou ser um estudo dos espaços que existem entre a História e a Literatura. Tenta ler a obra de Hemingway como um objeto de investigação privilegiado para o estudo da literatura no século XX, partindo daquilo que foi identificado em nossa pesquisa como a "superficialidade" e a "fragmentariedade" de sua forma narrativa. Isso quer dizer que a dissertação considerou não apenas os conteúdos de sua produção ficcional como historicamente relevantes, mas também a própria forma na qual esses conteúdos são apresentados.

\section{Palavras-chave:}

Historiografia; teoria crítica; século XX; superficialidade; fragmentação. 


\section{Abstract:}

Macieira, João Arthur; Jasmin, Marcelo Gantus. Ernest Hemingway between literature and history. Rio de Janeiro, 2021. 102 p. Dissertação de Mestrado - Departamento de História, Pontifícia Universidade Católica do Rio de Janeiro.

This dissertation investigates the relations between Literature and History as in the work of Ernest Hemingway. Here, we seek to dialogue with some of the main currents historiography and literary criticism, in order to point out some specificities in the production of this author. Less than a chapter on the History of Literature, the following text sought to be a study of the spaces that exists between History and Literature. It tries to read Hemingway' work as a privileged object of investigation for the study of literature in the 20th century, based on what was identified in our research as the "superficiality" and "fragmentation" of his narrative form. Finally, the dissertation considered not only the contents of his fictional production as historically relevant, but also the very form in which these contents are presented.

\section{Key-words:}

Historiography; critical theory; 20th century; superficiality; fragmentation. 


\section{Sumário}

1. Fragmentos da metrópole e a literatura moderna

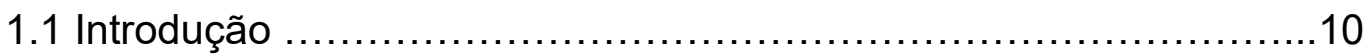

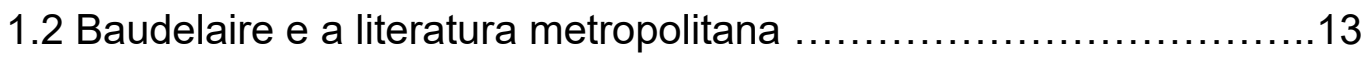

1.3 Os olhos dos pobres e a literatura antiburguesa de Baudelaire......18

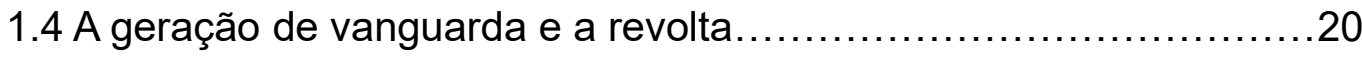

2. Os fragmentos de Hemingway: análise geral de suas formas narrativas

2.1 Introdução e uma pequena apresentação biográfica..................24

2.2 Fragmentação.................................................

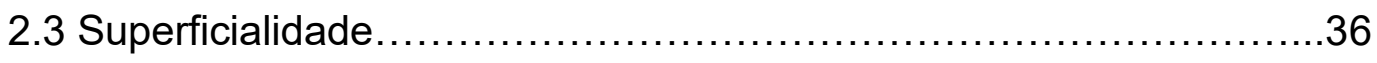

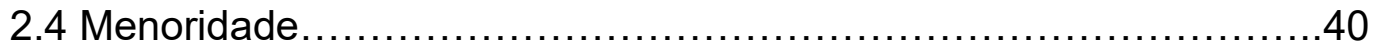

3. O Sol Também Se Levanta e a realidade fragmentada

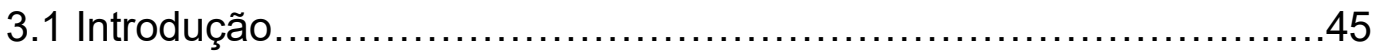

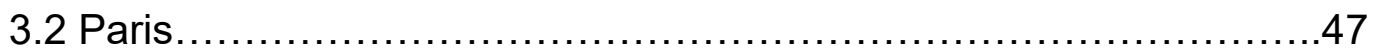

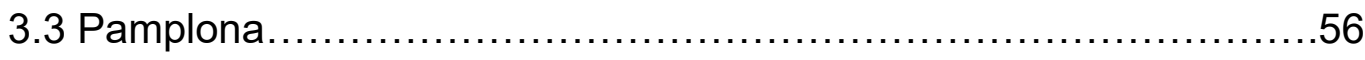

3.4 Madrid......................................................63

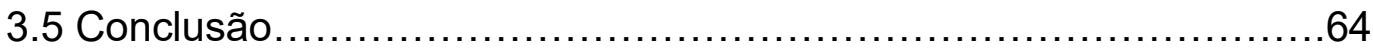

4. Tornar-se um com o touro: natureza segundo Ernest Hemingway

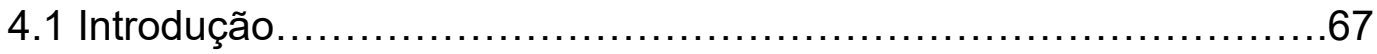

4.2 Ser um com o touro: o corpo-sem-órgãos de Hemingway.............68

5. Por Quem Os Sinos Dobram e O Velho e O Mar: máquinas paranoicas e devir-revolucionário

5.1 Introdução.......................................................

5.2 Linhas e máquinas na literatura de Hemingway ....................73 
6. The way to Hemingway: os problemas da recepção cubana

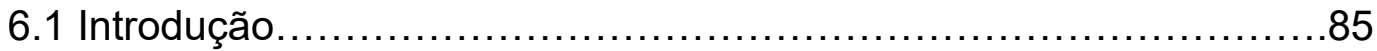

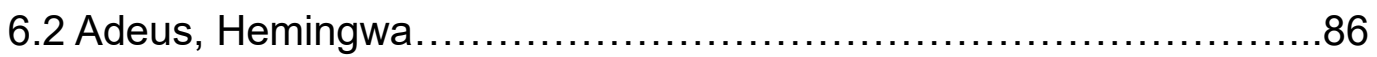

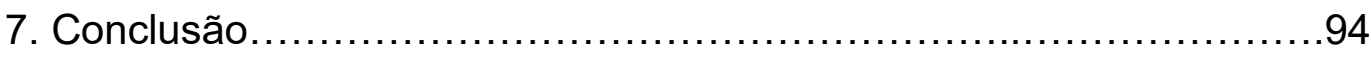

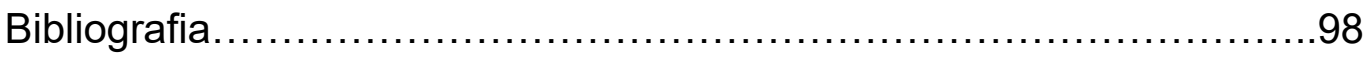




\section{Fragmentos da metrópole e a literatura moderna}

\section{1 - Introdução}

Tomaremos como ponto de partida de nossa análise as transformações sociais nos principais centros urbanos durante a transição do século XIX para o $\mathrm{XX}$, a fim de investigar que efeito tiveram na emergência de novas formas estéticas no campo da literatura. Durante o século XIX, não apenas a vida da alta cultura passa a ser, prioritariamente, metropolitana, como também burguesa. Isso terá consequências no mundo literário. Neste capítulo, observaremos o quanto Charles Baudelaire foi fundamental para que historiadores pudessem compreender esse contexto, uma vez que as transformações históricas, cujo início ocorreu na primeira metade do século XIX, receberam sua representação poético/literária na obra baudelairiana. A partir desse modelo de análise, apresentaremos aquele que mobilizará o nosso estudo de Ernest Hemingway.

Entendemos que esse processo de transformações sociais se estende até o início da Primeira Guerra, tornando ainda mais fortes as relações entre a vida nas grandes cidades e a literatura. Não foi ao acaso que as linguagens modernistas, em vertentes tão variadas quanto a literatura, as artes plásticas, arquitetura, moda e economia ${ }^{1}$ tiveram seu berço na metrópole. Como escreveu Marshall Berman, modernização (cuja expressão material mais concreta é a transformação urbanística das cidades) e modernismo são pares de um mesmo movimento histórico, inaugurado na Europa no início da modernidade ${ }^{2}$.

A metropolinização da literatura teve em Walter Benjamin um de seus analistas mais importantes. Seu Projeto (ou Trabalho) das Passagens ${ }^{3}$ aparece hoje como um dos projetos mais ambiciosos e complexos sobre a cultura no século XIX. A partir de uma perspectiva materialista-dialética, ainda que heterodoxa, investigou as transformações da cultura parisiense através dos

1 Este capítulo faz referência constante ao ensaio de Georg Simmel, As grandes cidades e a vida do Espírito. Rio de Janeiro: Revista Mana, 2007.

2 BERMAN, Marshall. Tudo que é sólido se desmancha no ar: a aventura da modernidade. São Paulo: Companhia das Letras, 1986.

3 BENJAMIN, Walter. Passagens. Vários tradutores. Belo Horizonte: Editora UFMG, 2018. 
objetos mais diversos, como adornos arquitetônicos, galerias, folhetins, obras poéticas e romanescas, luta de classes e muito mais. Tal diversidade tinha um objetivo: para esse filósofo alemão, Paris era a capital da modernidade durante o século XIX. -Dessa forma, o historiador entenderia a modernidade em toda sua complexidade por meio do estudo da cultura que fervilhava na cidade de Paris.

Nessa perspectiva, o trabalho de Walter Benjamin elaborou conceitos e interpretações tão originais como fantasmagoria e imagem dialética, produções teóricas debatidas entre especialistas até hoje. Desvendar a modernidade em sua complexidade a partir da cultura urbana parisiense não significava tratá-la como um objeto do passado, mas reconhecer nessa cultura sua temporalidade, não linear, sua persistência no tempo presente enquanto fantasmagoria. Vale aquilo que Koselleck disse sobre a "simultaneidade do não simultâneo" ${ }^{4}$ do tempo histórico, fórmula na qual nos referendamos para iluminar os ensaios que Benjamin escreveu sobre Charles Baudelaire 5

A metrópole será entendida como o espaço onde os sujeitos deverão não apenas lidar com uma temporalidade regulada e acelerada - em analogia ao desenvolvimento das forças industriais de produção e a organização capitalista do trabalho de praticamente todos os setores urbanas -, mas também em simultaneidade com outras temporalidades que convivem nesse mesmo espaço.

Os ensaios de Benjamin sobre Baudelaire também ajudam a entender a razão da ambiguidade de muitas avaliações críticas sobre os movimentos estéticos, assim como a respeito das transformações sociais e urbanas nas grandes cidades. O filósofo alemão identifica uma espécie de "ambiguidade intrínseca" à vida nas grandes metrópoles modernas.

O sociólogo alemão Georg $\operatorname{Simmel}^{6}$ foi o primeiro a estudar a vida cotidiana na grande metrópole, em suas formas ambíguas ${ }^{7}$. Com o nascimento da metrópole moderna, ocorreram transformações profundas na vida de seus habitantes, tão repentinamente que a vida nervosa desses sujeitos não logrou acompanhar a velocidade observada nas mudanças relativas à divisão do trabalho,

4 KOSELLECK, Reinhart. História, Histórias e Estruturas Temporais Formais em Futuro Passado: contribuição à semântica dos tempos históricos. Rio de Janeiro: Contraponto/PUC-Rio, 2006, p. 121.

5 BENJAMIN, Walter. Baudelaire a Modernidade. Belo Horizonte: Autêntica, 2015.

6 SIMMEL, Georg. op. cit., 2007.

7 SIMMEL, Georg. op. cit., 2007. 
aos meios de transporte ou à circulação urbana de pessoas e mercadorias. Era necessário determinado tipo de adaptação que levasse os sujeitos a suportarem o tipo de vida que emergia do chão sob seus pés.

Quais seriam as novas condições psíquicas e nervosas, essenciais ao indivíduo para que a experiência da realidade objetiva fosse suportável? Para Simmel, a resposta partiu da apresentação de duas tendências: em primeiro lugar, a descrição dos elementos práticos da vida na metrópole e suas exigências, ou seja, mostrar como viver nas grandes cidades, no início do século XX, exigia um investimento de atenção muito maior por parte de seus habitantes, tendo em vista os riscos que passaram a correr diante da velocidade dos objetos em circulação, do aumento das massas urbanas e da divisão social do trabalho. Em segundo lugar, fazia-se necessário apresentar as transformações "nervosas" - Simmel fala da vida subjetiva dos indivíduos também como uma "vida espiritual" - exigidas por essas acelerações na vida cotidiana.

Simmel resume as mutações ocorridas no seguinte trecho: "a vida citadina metamorfoseou a luta com a natureza por obtenção de alimento em uma luta entre os homens, de sorte que o ganho que se disputa não é concedido pela natureza, mas sim pelos homens"

A cidade, portanto, substitui a natureza enquanto espaço de luta pela sobrevivência dos homens, porém a velocidade que encontramos na metrópole é inigualável. Os efeitos mais significativos poderiam ser revelados na transformação das sensibilidades, identificável na forma pela qual os indivíduos precisam desenvolver modos de autoconservação diante de uma realidade objetiva exterior em constante movimento e aceleração. Essa autoconservação leva à formação de

\footnotetext{
um órgão protetor contra o desenraizamento com o qual as correntes e discrepâncias de seu meio exterior o ameaçam: ele reage não com o ânimo, mas, sobretudo, com o entendimento, para o que a intensificação da consciência, criada pela mesma causa, propicia a prerrogativa anímica?.
}

A metrópole, enquanto espaço hegemônico da ecologia do indivíduo

$8 \quad$ Idem, Ibidem, p. 587.

9 Idem, Ibidem, p. 578. 
moderno, transforma significativamente a sensibilidade humana, assim como alterações de larga escala nos espaços geográficos alterariam as formas de vida de qualquer espécie animal. $\mathrm{O}$ efeito decorrido da metropolinização, o "embotamento" individual, é a única maneira de garantir a convivência social.

Contraditoriamente, é a emergência da mentalidade blasé, um tipo de sensibilidade insensível, embotada, que torna possível a continuação da vida em sociedade. Para um indivíduo metropolitano do início do século $\mathrm{XX}$, seria absolutamente impraticável reagir de forma atenta à totalidade de estímulos trazidos pelo contato com a realidade externa da cidade; assim, torna-se, cada vez mais, insensível ao que lhe ocorre e ao que o circunda.

Veremos a seguir como o estudo da literatura serviu à investigação histórica desse período. No primeiro momento, é a Charles Baudelaire e à cidade de Paris que muitos pesquisadores vão recorrer para entender a vida metropolitana que emergiu entre o meio do século XIX e o início do XX. Avançadas algumas décadas no último século, muitos outros escritores serviriam para esse tipo de pesquisa, entre eles, Ernest Hemingway.

\section{2 - Baudelaire e a literatura metropolitana}

O tipo de literatura sensível ao processo comentado nas últimas páginas parece ter sido inaugurado por Charles Baudelaire ${ }^{10}$. Essa é a conclusão de Walter Benjamin, para quem não existe modernidade sem a obra de Baudelaire, o primeiro a teorizar sobre a complexidade histórica da estética moderna ${ }^{11}$.

Algumas dessas reflexões fundamentais sobre o papel e o destino da arte moderna se encontram no ensaio sobre Constantin Guys, $O$ pintor da vida moderna (1869), em que se ressaltam as diferenças entre o artista clássico e o moderno. O primeiro dependia de que suas obras obtivessem legitimidade por meio do recurso à tradição, que impunha limites ao indivíduo ao reproduzir fatos e personagens historicamente significativos $\mathrm{O}$ artista moderno, menos dependente do recurso à tradição, teria, entretanto, um trabalho muito mais exigente. A legitimidade dessa arte não estava garantida pelo conhecimento da tradição e pelo

10 BENJAMIN, Walter. op. cit., 2015.

11 BAUDELAIRE, Charles. Sobre a modernidade. São Paulo, Paz e Terra, 1996. 
domínio de suas técnicas. Dependia também da capacidade individual de mediar o conhecimento das tradições estéticas passadas com a observação, improvisação e seleção dos materiais oferecidos pelo presente imediato. Há, portanto, um duplo trabalho da arte moderna, que se volta, ao mesmo tempo, para o presente e para o passado.

Dessa forma, Benjamin argumenta que Baudelaire inaugura a Modernidade, não apenas a estética, desenvolvida em sua obra poética, que consiste tanto numa ruptura com os limites do que se conhecia até então, quanto no entendimento teórico a respeito de sua produção artística. Para Benjamim, o poeta francês representava um ponto alto na história da modernidade.

É claro que, apesar de recusar a submissão do presente ao passado e do indivíduo à História, a relação entre arte e história em Baudelaire não deixa de existir. Quando Baudelaire descreve o trabalho do artista moderno, é como se esse desejasse congelar o tempo presente para que pudesse representá-lo, lutando para que o imediato não lhe passe:

\begin{abstract}
à hora em que os outros estão dormindo, ele está curvado sobre sua mesa, lançando sobre uma folha de papel o mesmo olhar que há pouco dirigia às coisas, lutando com seu lápis, sua pena, seu pincel, lançando água do copo até o teto, limpando a pena na camisa, apressando, violento, ativo, como se temesse que as imagens lhe escapassem ${ }^{12}$.
\end{abstract}

Para captar essas formas de experiência da novidade constante, que Baudelaire fez presente no Spleen de Paris, seria preciso ter como referência um olhar tipicamente infantil: "A criança vê tudo como novidade; ela sempre está inebriada. Nada se parece tanto com o que chamamos inspiração quanto à alegria com que a criança absorve a forma e a cor ${ }^{13}$ ". Esse olhar infantil se contrapõe, é claro, ao olhar desinteressado do adulto blasé.

Contudo, há uma diferença muito clara entre a experiência da cidade através do que Baudelaire identifica no artista moderno e a experiência mediada pela chamada "mentalidade blasé", de Simmel. O tipo blasé seria o que Baudelaire chamara de dândi, o tipo que circula de modo desinteressado pela cidade, incapaz de apreender sensivelmente os estímulos trazidos pela constante novidade das mercadorias que não cessam de aparecer. Em contraposição ao

12 Idem, Ibidem, p. 22.

13 Idem, Ibidem, p. 17. 
dândi, há o artista moderno, o "homem do mundo", aquele que demonstra seu interesse pelo presente de forma compulsiva.

Unindo as definições dadas por esses dois autores, chega-se à conclusão de que o blasé é o contrário do infantil e que o artista é semelhante à criança:

O homem de gênio tem nervos sólidos; na criança, eles são fracos. Naquele, a razão ganhou um lugar considerável; nesta, a sensibilidade ocupa quase todo o seu ser. Mas o gênio é somente a infância redescoberta sem limites; a infância agora dotada, para expressar-se, de órgãos viris e do espírito analítico que lhe permitem ordenar a soma de materiais involuntariamente acumulada. É à curiosidade profunda e alegre que se deve atribuir o olhar fixo e animalmente estático das crianças diante do novo, seja o que for, rosto ou paisagem, luz, brilhos, cores, tecidos cintilantes, fascínio da beleza realçada pelo traje ${ }^{14}$.

Vê-se que, tanto no caso de Baudelaire quanto no de Simmel, a metrópole e a vida moderna foram objetos privilegiados na criação poética, no primeiro caso, e da reflexão sociológica, no segundo.

Para que essas rupturas pudessem aparecer, seria preciso que houvesse o espaço em que as novas formas de experiência da vida se dessem. Tais espaços serão, entre outros, os berços da arte moderna: apartamentos privados constantemente ocupados, restaurantes, bares e cafés; em suma, toda espécie de ambiente frequentado pela classe que dominará o cenário das artes desde o século XIX até o século XX: a burguesia boêmia. Um leitor de Paris é uma Festa, de Ernest Hemingway, poderá reconhecer o tipo de ambiente ocupado pela "geração perdida" em Paris, construído durante os anos de transformações arquitetônicas do Barão de Haussman.

O historiador Modris Eksteins observa que a inventividade artística e cultural das vanguardas da primeira década do século XX só foi possível depois dessas grandes transformações urbanísticas em Paris, iniciadas no meio do século XIX (intervenções “estético-estratégicas”, na linguagem de Benjamin).

Tais transformações possibilitaram o surgimento de espaços de coexistência entre sujeitos da mesma classe social, sem que tivessem que lidar diretamente com os efeitos da luta de classes, conferindo a suas existências o pertencimento à classe burguesa. Afinal, os artistas (mais boêmios do que burgueses) dependiam do contato com a burguesia parisiense para sobreviverem.

14 Idem, Ibidem, p. 18-19. 
Nesses espaços de vida noturna, surge um modelo presente até hoje do estilo de vida boêmio, que será crucial para a formação dos escritores e artistas modernistas do século XX, como anotou Modris Eksteins:

A partir de meados do século passado, a cidade havia realmente contribuído muito para encorajar essa imagem: desde os consideráveis melhoramentos introduzidos na cidade sob a direção do prefeito do Sena na época de Louis Napoleon, o Barão Haussmann, à repetida organização de pródigas e dispendiosas exposições mundiais, aos acréscimos e aperfeiçoamentos arquitetônicos feitos por pessoas como Violet-le-Duc, à construção da Torre Eiffel e do Sacré Coeur, às leis de censura relativamente frouxas que permitiam diversões e publicações que teriam pouca chance de sobrevivência em qualquer outra parte da Europa, e, finalmente, à moralidade intencionalmente ambígua, moralidade não encontrada em nenhuma outra parte da Europa, que tolerava uma vida de rua cheia de absinto, cafés e garotas ${ }^{15}$.

Como comentamos, a construção desses espaços liberais de livre convivência para burgueses e boêmios, afastados das perturbações trazidas pelos efeitos da luta de classes, não existia sem uma contrapartida material bastante repressiva. Nas Passagens, Walter Benjamin reconhece, na nova estrutura urbanística da cidade, a expressão da luta de classes moderna, portanto, uma relação direta entre o aburguesamento de determinados espaços urbanos na zona central de Paris e o agravamento das condições de vida do proletariado nas periferias.

Essas não são transformações puramente técnicas ou estéticas, mas medidas de contenção das classes sociais perigosas. Benjamin é claro na sua conclusão: "O aumento dos aluguéis impele o proletariado para os subúrbios. Com isso, os bairros de Paris perdem sua fisionomia própria. Surge o 'cinturão vermelho' operário ${ }^{16}$."

Outro historiador como Modris Eksteins, de uma perspectiva não marxista, também não ignora o fato de que a formação da cultura burguesa parisiense dependeu de processos de concentração de renda e de expulsão das classes proletárias da zona central.

Eksteins comenta que, no desejo de construir o "centro da cidade mais belo do mundo", o processo de modernização da cidade também criou um

15 EKSTEINS, Modris. op. cit., p. 68.

16 BENJAMIN, Walter. op. cit., 2018. 
subúrbio que estava "entre os mais feios". A geografia da metrópole será simplificada, dividida entre um centro, cuja vida cultural foi a mais desenvolvida da Europa, e as periferias:

\begin{abstract}
Aubervilliers, Les Lilas e Issy-les-Moulineaux, construídos nos últimos vinte e cinco anos do século XIX, numa tentativa de contraatacar o congestionamento, são nomes líricos para sombrios subúrbios industriais. Eram numerosos os bairros miseráveis sem saneamento adequado; em 1850, apenas uma em cinco casas tinha água. Paris era incontestavelmente a capital ocidental dos vagabundos e mendigos ${ }^{17}$.
\end{abstract}

Essa geografia não poderia passar sem efeitos na formação da estética presente na literatura e nas artes modernas. Um terceiro autor que escreveu sobre os efeitos sociais das transformações na cidade de Paris, no século XIX, foi o filósofo norte-americano Marshall Berman ${ }^{18}$. A interpretação "faustiana" de Berman separa dois processos (um, econômico-social; outro, estético-cultural) no período indicado: modernização versus modernismo. Nessa dualidade, reside o caráter trágico da própria natureza daquilo que podemos reunir sob o título de Modernidade: o modernismo é uma atitude de desprendimento, a libertação de vínculos tradicionais e "desencaixante" (modificando a expressão do sociólogo inglês Anthony Giddens ${ }^{19}$ ): seu resultado final é produtivo, vide as obras artísticas e arquitetônicas, frutos do período. Modernização, por outro lado, é o processo de alienação capitalista, que altera as relações de pessoas entre as pessoas para relações entre pessoas e coisas - do qual, por sua vez, o modernismo prescinde.

No resultado da união entre modernismo e modernização, encontram-se formas trágicas do espírito moderno: "Grandes e majestosas perspectivas foram desenhadas, com monumentos erigidos no extremo dos bulevares, de modo que cada passeio conduzisse a um clímax dramático ${ }^{20}$ ". Tais formas serão a base para o crescimento e a consolidação de "gerações de pintores, escritores e fotógrafos modernos (e, um pouco mais tarde, de cineastas), começando com os impressionistas em 1860, nutrir-se-iam da vida e da energia que escoavam ao longo dos bulevares ${ }^{21}$ ".

17 EKSTEINS, Modris. op. cit., p. 69.

18 BERMAN, Marshall. op. cit., 1986.

19 GIDDENS, Anthony. As consequências da Modernidade. São Paulo: Editora Unesp, 1991.

20 BERMAN, Marshall. op. cit., p. 146.

21 Idem, Ibidem. 
Depois de Paris, outras grandes cidades a imitariam, assim como, depois da consolidação da estética parisiense, outros movimentos artísticos modernistas vão se desenvolver em suas próprias cidades. Uma última referência pode ser feita a T.J. Clark, poeta e crítico de arte inglês ${ }^{22}$. Em seu trabalho, fazia uma crítica à impressão de que tais realizações modernas pudessem ser atribuídas somente ao gênio e ao desejo dos políticos e homens de Estado, como o barão de Haussmann ou Luís Napoleão III. É contra essa expectativa de ver no prefeito de Paris ou no imperador francês o grande idealizador da metrópole moderna (e, portanto, vilão de suas injustiças sociais) que T.J. Clark tece alguns de seus comentários: "Só havia favores, negociatas, corrupção, diziam aqueles que queriam sua parte nas três coisas".

\section{3 - Os olhos dos pobres e a literatura metropolitana antiburguesa de Baudelaire}

A metrópole moderna criou uma diversidade infinita de formas de experiência de seus espaços. Desejamos, ainda, apresentar como a literatura moderna identificou e reduziu essas experiências a duas formas contraditórias, partindo de um pequeno poema em prosa de Charles Baudelaire. A forma da cidade, de fato, parece ter privilegiado um tipo de divisão social entre pobres e ricos. Contudo, é de se notar que o texto analisado a seguir implica uma segunda divisão: a do narrador (do Eu), que observa os processos de incessante movimento e esse mundo exterior. Apartado o indivíduo burguês, não apenas do resto da sociedade numa classe de proprietários, mas ele mesmo entendido como alguém que se afasta do mundo no qual está inserido, assim, o caminho está trilhado para os processos de atomização social, identificados por Hannah Arendt (como veremos, mais à frente).

Num dos poemas em prosa de $O$ Spleen de Paris, "Os olhos dos pobres"23, o narrador inicia o texto testemunhando um dos novos espaços de convivência (ainda em construção) para a nascente burguesia boêmia parisiense:

você quis se sentar num café novo na esquina de um bulevar novo,

22 CLARK, T. J. A pintura da vida moderna: Paris na arte de Monet e seus seguidores. São Paulo: Companhia das Letras, 2004.

23 BAUDELAIRE, Charles. O Spleen de Paris: pequenos poemas em prosa. São Paulo: Hedra, 2009. 
todo sujo ainda de entulho e já mostrando gloriosamente seus esplendores inacabados. $\mathrm{O}$ café resplandecia. $\mathrm{O}$ próprio gás disseminava ali todo o ardor de uma estreia e iluminava com todas as suas forças as paredes ofuscantes de brancura ${ }^{24}$.

$\mathrm{O}$ acesso do narrador às novidades da vida boêmia parisiense, entretanto, não sem algum grau de impureza. Dessa forma, logo aparecem as primeiras vítimas dos processos de modernização da metrópole, mesmo pequeno texto. $\mathrm{O}$ narrador do poema descreve o ambiente como uma miscelânea de objetos absolutamente incoerentes: "obelisco bicolor dos sorvetes matizados", "pajens de caras rechonchudas", "as damas rindo para o falcão em suas mãos".

Os objetos que circulam ao redor do narrador não entram numa relação entre eles, mas parecem ocupar seus espaços apenas como mercadorias ou adornos adequados para um espaço a ser preenchido por uma classe de sujeitos afeita a extravagâncias. Só a narração cria um ponto fixo de referência para a circulação desses objetos (o próprio narrador) e ele mesmo não experimenta uma vertigem ou ingressa em contemplação da cena. Pelo contrário, aquilo que poderia caracterizar sua presença é a sua apatia (l'ennui, o tédio, motivo recorrente da poesia baudelariana). $\mathrm{O}$ ambiente interno do café é um microcosmo burguês da vida na metrópole, que bombardeia igualmente os indivíduos com estímulos nervosos, obrigando-os àquele comportamento identificado por Simmel como blasé.

A indiferença do narrador, que vê o interior do recém- construído café como se já estivesse cansado daquilo, é também a produção de um espírito contrário à cultura moderna. Há um mal-estar, uma desavença entre o pequeno burguês de sensibilidade poética que narra esse poema e a classe social representada pelos personagens que o cercam ${ }^{25}$. Logo em seguida, observaremos com quem esse narrador preferiria firmar uma nova solidariedade. Torna-se bem clara a posição do narrador: "toda a história e toda a mitologia a serviço da comilança". Isso prepara o leitor para a descrição da família de pobres, que contrasta, radicalmente, não apenas com o ambiente do café, como também com a temporalidade acelerada e festiva, o que fica demonstrado na simplicidade e lentidão da fala que o filho dirige ao pai: "mas é um lugar onde apenas pessoas

24 Idem, Ibidem.

25 Sobre isso, ver OEHLER, Dolf. Quadros Parisienses: estética antiburguesa (1830-1848). São

Paulo: Companhia das Letras, 1997. 
que não são como nós podem entrar ${ }^{26 "}$. Quando os olhos desses pobres e os olhos do narrador se encontram, o leitor chega ao ponto alto do texto. $\mathrm{O}$ pequeno burguês e o poeta entediado com a própria condição social são arrancados pela simplicidade do maravilhamento dos pobres diante do café - o mesmo no qual o poeta não vê coisa alguma. $\mathrm{O}$ encantamento dos que são proibidos de entrar encontra o tédio de quem sempre está por ali. Os problemas acarretados por esse tipo de visão são previsíveis: paternalização e romanticização das camadas pobres da cidade, visão que encontrou um contraponto em Zola ${ }^{27}$.

\section{4 - A geração de vanguarda e a revolta}

O motivo antiburguês de Baudelaire, entretanto, não será o mesmo que aquele das gerações de vanguarda, uma vez que ganhará expressão muito mais destrutiva no plano material das sociedades europeias. Além das rupturas estéticas que o modernismo performa no fim do século XIX, parece-nos interessante também chamar atenção ao caráter de ruptura moral do modernismo. Assim como modernismo estético, a ruptura de valores morais é um fato histórico metropolitano, que ganha espaço simultaneamente em diversas capitais europeias. Os movimentos de vanguardas no século XX foram, na sua esmagadora maioria, oriundos dos grandes centros urbanos, bem como os ulteriores modernismos estéticos europeus, norte e latino-americanos. Essa raiz metropolitana terá efeitos significativos na formação de seus valores e objetivos, aproximando suas realizações daquele mundo que vinha sendo construído desde a metade do século XIX: as das grandes capitais e da burguesia boêmia. Começando na pequena burguesia boêmia (pensemos no narrador de Baudelaire acima), chegando aos vanguardistas do século XX, essa classe de artistas terá papel crucial na formação da imaginação estética e moral do último século:

só a boêmia, como espécie de organização da vida literária fora da organização da sociedade, podia oferecer o clima para o empreendimento audacioso de alguns pintores e poetas de destruir o mundo existente e criar outro. Com efeito, o modernismo nasceu quase simultaneamente em quatro lugares diferentes - em Paris, Florença, Nova Iorque e Berlim - e sempre num ambiente de boêmia ${ }^{28}$.

26 BAUDELAIRE, Charles. op. cit.

27 ZOLA, Émile. Germinal. Paris: Gallimard, 1999.

28 CARPEAUX, Otto Maria. op. cit., p. 2468. 
Foram importantes, como sempre, as relações estabelecidas entre esses movimentos artísticos e literários e as principais correntes filosóficas do período. Hannah Arendt chega mesmo a identificar três "pais espirituais da vanguarda" 29 . A seleção dos três autores (Marx, Nietzsche e Kierkegaard) deve-se à reelaboração empreendida por eles sobre o conceito de valor. Essa reelaboração seria de extrema importância para a consolidação dos principais motivos morais da geração de vanguarda do século XX. Contudo, uma diferença fundamental se estabelece entre esses autores e seus filhos: aqueles acreditavam que o movimento de ruptura com a tradição levaria a novos fundamentos, portanto, a categorias mais altas de valores. Os vanguardistas, segundo Arendt, tomaram a destruição intelectual empreendida pelos pais espirituais como um motivo em si mesmo, tendo, portanto, a pura ruptura como horizonte de expectativas:

\section{(...) é verdade que a "geração de vanguarda", em agudo contraste com os pais espirituais que ela mesma havia escolhido, estava completamente absorvida pelo desejo de ver a ruína de todo este mundo de segurança falsa, cultura falsa e vida falsa. Esse desejo era tão forte que o seu impacto e eloquência eram maiores que os de todas as tentativas anteriores de 'transformação de valores', como a de Nietzsche (...). Certamente, não é possível dizer que Arendt acredite que essa condição seja total, sendo ela mesma uma jovem nos primeiros anos do século XX. Destruição sem piedade, o caos e a ruína assumiam a dignidade de valores supremos ${ }^{30}$.}

O vácuo moral, potencializado pela atomização individual que caracteriza a sociedade burguesa, seria enfim ocupado pelas ideologias totalitárias, que emergem logo em seguida ao declínio da vanguarda. Veremos a seguir como dois outros estudos nos auxiliam a compreender o processo. Stuart Hughes, historiador, indica o ponto nevrálgico da formação estética e filosófica das vanguardas naquilo que chamou de "redescoberta do inconsciente 31 ". Da geração de Max Weber a Benedetto Croce e Henri Bergson, a atividade intelectual e artística do período é atravessada pela noção de que os indivíduos são conduzidos mais pelas forças irracionais do que por processos racionais. Em termos políticos, Hughes entende

29 ARENDT, Hannah. As Origens do Totalitarismo: Imperialismo, Antissemitismo e Totalitarismo. São Paulo: Companhia das Letras, 1998.

30 Idem, Ibidem, p. 378.

31 HUGHES, Stuart. Consciousness and Society: The Reorientation of European Social Thought, 1890-1930. New York: Alfred A. Knopf, 1958. 
essa geração como reacionária: a preferência filosófica pela liberação dos desejos em lugar dos processos racionais ganha espaço entre os quadros jovens de intelectuais reacionários:

Durante os anos imediatamente anteriores ao estopim da Guerra, aqui reinou entre os jovens um espírito que combinava respeito pela autoridade com o culto da criação espontânea (...). Por um lado, eles [historiadores estudiosos do período] acharam nele [o movimento vanguardista] uma ameaçadora atmosfera protofascista, por outro lado, acharam uma renascença da cultura e uma cortante brutalidade viva enquanto começava ${ }^{32}$.

Um curioso desejo de substituir a vida burguesa de seus pais se instalou entre os jovens das camadas mais intelectualizadas da sociedade europeia. Ao ponto que

eles adularam o irrompimento da matança com entusiasmo. Os mais belicosos sentiram finalmente ao seu alcance a vida de ação pela qual esperavam. Os mais reflexivos a bem receberam [a Guerra] como o desenrolar de uma antecipação infrutífera: "Melhor que a guerra venha", eles repetiam, "do que continuar com essa espera",33.

Veremos que essas mesmas questões são também recorrentes em $O$ Sol Também Se Levanta (1926). O jovem Ernest Hemingway era, ele mesmo, um indivíduo pertencente àquela geração de jovens que abandonou uma vida numa grande cidade (Kansas City) para ir à Primeira Guerra. Ele também encontrará um vazio moral, deixado tanto pelas vivências da guerra quanto pela sociedade que encontra ao retornar dela, incapaz de reabsorvê-lo organicamente. Um dos contos mais ilustrativos desse movimento de fuga e retorno estranhado é Soldier's $H_{o m e}{ }^{34}$, no qual se narra o retorno frustrado da Primeira Guerra de um jovem do interior do Oklahoma. Sem glórias, sem feitos heroicos, sem reconhecimento de sua comunidade, o soldado que retorna percebe sua própria atividade na guerra como uma nulidade. Mas aquele que retorna é incapaz de deixar suas experiências para trás e torna-se, ele mesmo, uma nulidade. O personagem é incapaz de integrar-se de novo na sua comunidade de origem: quaisquer vias the pareciam fechadas. Resta-lhe reingressar na vida da grande cidade, mudando-se para Kansas City.

32 Idem, Ibidem, p. 344

33 Idem, Ibidem.

34 HEMINGWAY, Ernest. The Short Stories. Nova York: Scribner's and Sons, 1995. 
Os relatos biográficos do jovem Hemingway atestam uma similaridade tremenda entre o personagem e o próprio autor, durante o período em que esse retorna da Primeira Guerra para a casa dos pais em Oak Park. Hemingway, como seu personagem, e muitos de sua geração encontraram na escrita uma forma de se recriarem, uma vez que se viram, ao mesmo tempo, desprovidos de experiências épicas da Guerra e impedidos de uma reinserção na sociedade da qual provinham. O jovem Hemingway retornará da Guerra na Europa pensando nos Estados Unidos como "um país maldito" 35 ".

35 HEMINGWAY, Ernest. As Cartas de Ernest Hemingway: 1907-1922. São Paulo: Martins Fontes, 2015. 


\section{Os fragmentos de Hemingway: análise geral de suas formas narrativas}

\section{1 - Introdução e uma pequena apresentação biográfica}

O primeiro capítulo desta dissertação buscou identificar determinados fatores históricos significativos para explicar a formação de uma literatura e também de um tipo específico de sensibilidade nas sociedades ocidentais que atravessaram o fim do século XIX e as primeiras duas décadas do século XX. Se é inegável que um autor não pode ser reduzido às circunstâncias materiais e ao contexto social e político nos quais se insere, ao mesmo tempo, seria impossível desconsiderar a influência que as discussões estéticas e as linguagens exerceriam na produção de suas obras.

Vimos, ao visitar as análises de Benjamin, Eksteins, Arendt e Hughes, que dois elementos cruciais para a atividade literária foram significativamente impactados pela guerra de 1914-1918: os valores morais e as linguagens artísticas. Ainda que cada um dos autores citados acima utilize argumentos diferentes, a conclusão a que chegam sobre a literatura e as artes de maneira geral é similar: elas assumiram caráter de ruptura radical com o passado, ao menos, a partir da virada para o século XX, intensificando-se o processo depois da Primeira Guerra.

Contudo, ainda é difícil compreender o que significaria essa ruptura com o passado, uma vez que, por si só, tal movimento não oferece uma perspectiva concreta do caminho que desejaria trilhar. Na verdade, a conclusão geral que se pode retirar da leitura desses historiadores e filósofos é a da perda dos horizontes de expectativas, decorrente da destruição - material e imaterial - dos espaços de experiência ${ }^{36}$ durante o período compreendido do final do XIX até o início da segunda década do XX.

36 KOSELLECK, Reinhart. A semântica histórico-política dos conceitos antitéticos assimétricos em Futuro Passado: contribuição à semântica dos tempos históricos. Rio de Janeiro: Contraponto/Editora PUC-Rio, 2006. 
Como bem identificou Hannah Arendt, durante o século XIX, já estavam presentes origens filosóficas desse processo, identificadas por Arendt no universo intelectual. Ao destacar o trabalho elaborado por Soren Kierkegaard, Friedrich Nietzsche e Karl Marx de reelaboração do conceito de valor, Arendt apresenta a convergência entre uma tendência, presente no mundo intelectual, com outra, presente concretamente na sociedade, o que se denomina condição atomizada do indivíduo na sociedade burguesa ${ }^{37}$. Processo similar ao que Walter Benjamin comenta no famoso ensaio sobre a morte do narrador ${ }^{38}$ (que, não por acaso, coincide com o que foi chamado de "ascensão do romance" ${ }^{39}$ ): ainda que se refiram a objetos diferentes e sejam analisados de maneiras metodologicamente diversas, ambos parecem falar fundamentalmente de um mesmo fenômeno histórico de longa duração, que culmina no século XX na forma de grandes eventos destrutivos, mas dos quais nada de novo parece emergir.

Ernest Hemingway amadurece; sua primeira produção literária aparece poucos anos depois do fim da Primeira Guerra. Por estar inserida no olho desse furação estético, social e histórico, essa obra - ainda que fortemente influenciada por uma geração de poetas e escritores que defendiam a autonomia de sua arte em relação à sociedade - não escaparia da discussão. Evidentemente, isso não significa o mesmo que dizer que seus contos e romances se resumem a uma espécie de representação estética do período no qual foram produzidos. É possível identificar em sua literaura, por meio de tramas, personagens e formas narrativas, os mesmos problemas discutidos pelos historiadores e filósofos citados, reelaborados literariamente.

Neste capítulo, pretende-se apresentar uma análise geral de suas formas narrativas, fazendo referência a três conceitos que parecem fundamentais: fragmentação, superficialidade e menoridade. Temos como referência para a utilização desses conceitos a leitura feita por Gilles Deleuze, que toma esses três elementos como chave de estruturação da literatura estadunidense ${ }^{40}$. Antes, porém,

37 ARENDT, Hannah. Origens do Totalitarismo: imperialismo, antissemitismo, totalitarismo. São Paulo: Companhia das Letras, 1998.

38 BENJAMIN, Walter. O narrador - considerações sobre a obra de Nikolai Leskov em Magia e técnica, arte e politica: ensaios sobre literatura e história da cultura - Obras Escolhidas I, trad. Sergio Paulo Rouanet, São Paulo: Brasiliense, 1987.

39 WATT, Ian. A ascensão do romance: estudos sobre Defoe, Richardson e Fielding. São Paulo: Companhia das Letras, 2010.

40 Ver DELEUZE, Gilles. Crítica e Clínica. São Paulo: Editora 34, 1997. 
encontraremos vantagem se fizermos uma visita à biografia de Hemingway ${ }^{41}$, tendo em vista sua pequena difusão no meio acadêmico brasileiro.

Nascido ainda no século XIX, em 1899, Ernest Hemingway vem ao mundo na pacata Oak Park, cidade do interior do estado de Illinois, nos Estados Unidos. Seu pai era médico e parece ter tido um papel crucial na formação de sua vida psicológica, mais por sua ausência de espírito do que por excessiva presença. O suicídio era um fantasma presente em sua família, cometido por seu pai e por um número significativo de outros membros, incluindo o próprio Ernest. Ainda em sua adolescência, Hemingway guardava opiniões muito negativas sobre seu pai, e é possível reconhecer, em alguns de seus primeiros contos, os mesmos sentimentos e angústias demonstradas em sua correspondência ${ }^{42}$. Sua mãe, além de professar a religião protestante de forma rígida, parece ter tomado a família como objeto de descarga de suas frustrações, depois de falhar na carreira de cantora profissional. Ernest parece ter sido um dos mais afetados pela união dessas duas figuras; enquanto criança, desenvolveu o hábito da automutilação, para que fosse desnecessário a seus pais the aplicar um castigo.

O jovem Ernest Hemingway foi um entusiasta dos esportes de aventura e da vida ao ar livre. A literatura, naquele momento, parece não ter tido tanto espaço. Já era grande nesses anos, ainda que não tão robusto quanto seria em anos futuros, quando, finalmente, assumiu a forma viril com a qual será lembrado, mas não era um grande atleta nos esportes coletivos. Estar sozinho nas florestas que cercavam sua casa, ter sua pele em contato com o ar frio e as águas geladas de rios e lagos no interior do Michigan era muito mais prazeroso do que qualquer evento social. Somente ao final da juventude, começou a lutar boxe, esporte no qual era realmente destacado - e que, segundo o próprio autor, ensinou a Ezra Pound, em troca de aulas de poesia.

Findo o período escolar, foi a hora em que a escrita e as relações amorosas entraram realmente em sua vida. Nos anos de colégio, já havia participado do jornal escolar, mas só então pode levar a sério essa atividade e, por meio de

41 As informações biográficas se baseiam em BAKER, Carlos. Ernest Hemingway: o romance de uma vida. Rio de Janeiro: Civilização Brasileira, 1971; e HOTCHNER, A. E. Papa Hemingway. Rio de Janeiro: Civilização Brasileira, 1967.

42 HEMINGWAY, Ernest. As Cartas de Ernest Hemingway: 1907-1922. São Paulo: Martins Fontes, 2015. 
contatos intermediados por sua família, foi trabalhar num grande jornal do MeioOeste, o Kansas City Star. Hemingway cobria crimes em Kansas City e, apesar de ser apenas um iniciante sem nenhuma experiência, suas cartas daquele período acusam uma boa relação com toda a equipe do jornal. O autor dá destaque a essa época, considerando as regras da escrita jornalística como um dos fundamentos de seu próprio estilo literário.

A decisão de deixar a pacata Oak Park e se mudar para uma grande cidade como Kansas City pode ser visto como o primeiro sinal de uma insatisfação que o jovem Hemingway sentia em relação ao tipo de vida que sua família desejava para seu futuro, às restrições e ao moralismo religioso que lhe impunham. Essa revolta contra os pais - tão similar àquilo que Stuart Hughes viu nas vanguardas europeias $^{43}$, ainda que mais suave - teria causas e efeitos que, provavelmente, excedem os limites das explicações psicologizantes. Mesmo antes dos vinte anos, Hemingway percebera que não haveria lugar para ele e para seus desejos na comunidade onde nascera, mas logo uma grande cidade como Kansas City também se mostrou insuficiente. Em 1918, Hemingway deixou o Missouri, alistou-se na Cruz Vermelha Italiana, tendo chegado ao front austríaco do combate. Havia sido rejeitado no exército norte-americano, provavelmente, porque tinha uma visão imperfeita; mas ainda parece surpreendente que estivesse disposto a arriscar-se na Grande Guerra, lutando por um país com o qual não possuía nenhuma ligação ou sobre o qual soubesse alguma coisa. $\mathrm{O}$ autor diz a Hotchner, um de seus biógrafos, que foi, acompanhando de perto o trabalho de redação do Kansas City Star, que Ernest decidiu oferecer-se como voluntário na Guerra. Parece ter ficado impressionado com os relatos que o jornal recebia e pensou que poderia ser uma oportunidade de ganhar experiência num evento marcante. Entretanto, não combateu diariamente nos embates contra as forças inimigas, tendo sido o seu papel dirigir ambulâncias.

Foi um período curto que Hemingway passou na Europa, mas que o marcou profundamente, em diversos sentidos. Fisicamente, seu joelho foi completamente destruído com a explosão de um morteiro, durante um ataque austríaco ao front italiano em que servia. Parece que, por muito pouco, não teve a

43 HUGHES, Stuart. Consciousness and Society: The Reorientation of European Social Thought, 1890-1930. New York: Alfred A. Knopf, 1958. 
perna amputada; todo leitor de Adeus às Armas (1929) vai reconhecer que essas experiências foram aproveitadas na construção do romance e da figura de Fredric Henry. Mas esse não foi o único trauma pelo qual o ainda jovem Hemingway atravessou. No hospital milanês, onde foi operado, ele conhece a enfermeira inglesa Agnes von Kurowsky. Apaixona-se profundamente e, de fato, acredita que vai se casar com ela, planejando seu futuro, mesmo depois de retornar aos Estados Unidos. Essa experiência também foi aproveitada em Adeus às Armas, sendo nítidas as semelhanças entre Agnes e a personagem Catherine Barkley. Contudo, também no pequeno conto (de título irônico) A Very Short Story ${ }^{44}$, uma relação entre personagens muito próximos a Henry e Barkley aparece de forma grotesca.

Na vida de Hemingway, o desfecho de sua relação não é nem trágico, nem grotesco, mas será suficiente para enfurecê-lo e decepcioná-lo de forma muito mais intensa do que o episódio da explosão, que, por muito pouco, não lhe fez perder uma perna e até a vida. A importância desses eventos não é só psicológica, como também literária: a destrutividade espontânea da guerra, os resultados trágicos e/ou grotescos de pequenas decisões e sua falta de sentido generalizada serão importantes na constituição de sua literatura. Assim também, a efemeridade, a transitoriedade e a crueldade que existem nas relações amorosas aparecerão como tema de muitos de seus textos. Não foram poucos personagens de Hemingway que sofreram traumas em decorrência de combates e quase todos os seus protagonistas possuem alguma relação com a guerra, principalmente com a de 1914-1918. Isso, contudo, não o faz um escritor de literatura de guerra - basta pensar no tipo de sistematização e teorização que tal literatura encontra em autores como Siegfried Sasson ${ }^{45}$ ou Ernest Jünger ${ }^{46}$ para que se reconheçam diferenças muito significativas. A guerra - ou melhor, as guerras - pelas quais Hemingway vai atravessar durante sua vida marcam profundamente sua literatura, mas também o fazem as florestas e os lagos do Michigan, sua infância em Illinois, as mulheres e os homens com quem se relacionou, as touradas, pescarias e caçadas em que participou, os romances e jornais que leu ou os filmes a que assistiu.

44 HEMINGWAY, Ernest. The Short Stories. Nova York: Scribner's and Sons, 1995. 45 SASSON, Siegfried. Memórias de um Oficial de Infantaria. São Paulo: Mundaréu, 2014. 46 JÜNGER, Ernst. Tempestades de Aço. São Paulo: Cosac \& Naify, 2013. 
De volta aos Estados Unidos, a sensação de estranhamento não é compensada pelo reconhecimento que recebe enquanto veterano de guerra, mas parece ser mesmo atenuada por isso. No conto A Volta do Soldado (Soldier's Home), escrito já em Paris, Hemingway explora essa atmosfera na figura do personagem Howard Krebs, um rapaz que retorna ao interior do Oklahoma depois de combater na Grande Guerra. Krebs, ao voltar, reconhece que perdeu a capacidade de amar - não apenas a si mesmo e a sua família, mas a qualquer um. Seu retorno faz dele uma espécie de indigente, que vaga por sua cidade contando histórias falsas do tempo em que passou na guerra, além de observar meninas novas demais para se tornarem suas companheiras. Como solução, muda-se, justamente, para Kansas City. Assim como seu personagem, Hemingway decide deixar, mais uma vez, a cidade natal, mudando-se primeiro para Toronto e, depois, para Chicago, onde volta a trabalhar como jornalista. Depois de conhecer Hadley Richardson e casar-se com ela, atravessam o Oceano Atlântico até Paris: era o primeiro passo do plano de Hemingway para se tornar um escritor.

Depois de conhecer o escritor Sherwood Anderson, ainda nos Estados Unidos, Hemingway conseguiu recomendações para se apresentar aos escritores estadunidenses que viviam em Paris. Foi quando conheceu Ezra Pound, Scott Fitzgerald e Gertrude Stein. Sua proximidade com Stein permitiu que discutisse, pela primeira vez, artes e a literatura de forma alongada e crítica. Esse contato parece ter sido determinante para a educação estética do autor, não só porque ela lhe serviu como uma espécie de revisora particular, mas também por ter-lhe apresentado Silvia Beach, proprietária da famosa livraria Shakespeare and Company, fonte de empréstimos e de compras fiadas. É quando pode ler e discutir autores como Mark Twain, Dostoiévski e Flaubert com outros escritores, situação muito improvável entre os jornalistas americanos com que vinha trabalhando.

A situação financeira de Ernest Hemingway e sua esposa foi parcialmente descrita por ele mesmo num artigo para o Toronto Daily Star, no qual convida qualquer estadunidense/canadense com U\$ 1000,00 de rendimentos a passar um ano na Europa, sem terem de se preocupar com emprego. A desvalorização das moedas europeias perante o dólar permitiu que as classes médias norte-americanas fizessem verdadeiras peregrinações, como as que são descritas em O Sol Também 
Se Levanta. O casal vive mesmo é do dinheiro de sua esposa, apesar de Hemingway escrever com alguma regularidade para o Toronto Daily Star. Ainda em $O$ Sol Também Se Levanta é possível reconhecer algumas consequências da vida descolada da realidade do trabalho e da própria cidade em que vivem os personagens. O convívio de Hemingway se dá entre escritores, pintores, escultores, livreiros e jornalistas internacionais, mas - como diz Bill Gorton a Jacob Banres - ele "vive como um expatriado". Como Jacob Barnes, ainda que tenha vivido em Paris, durante anos, nunca foi próximo de nenhum francês (ao menos, nenhum que não fosse seu empregado ou ligado ao mundo das artes): os escritores da chamada geração perdida viviam numa espécie de bolha, flutuando sobre Paris e a Europa. Embora tenham produzido romances e poemas dos mais significativos para a história recente da literatura de língua inglesa, tinham pouco ou nada da figura do escritor enquanto intelectual público, que dominaria o cenário político europeu nos anos seguintes (bastaria pensar em Jean-Paul Sartre, como exemplo paradigmático). $\mathrm{O}$ descolamento em relação à realidade não tem caráter apenas sociológico, mas - como observa Otto Maria Carpeaux ${ }^{47}$ - é também um dos motivos centrais da inventividade estética do modernismo literário na primeira metade do século XX. Para Carpeaux, só assim é possível compreender os grandes movimentos e obras modernistas, desde o futurismo até o Ulisses, de James Joyce.

Como entender o tipo de narrativa desenvolvido por Hemingway, diante das considerações biográficas e históricas tomadas até agora? Tentaremos esclarecer esse ponto retomando as reflexões de Deleuze sobre a particularidade da literatura norte-americana, analisando a obra de Hemingway a partir dos conceitos de fragmentação, superficialidade e menoridade.

\subsection{Fragmentação}

Nos seus escritos, Deleuze traça uma linha que vai desde Whitman e Melville até Jack Kerouac, identificando alguns motivos fundamentais da literatura americana. É possível reconhecer muito daquilo que Deleuze viu nesses

47 CARPEAUX, Otto Maria. As revoltas modernistas em História da Literatura Ocidental - v. IV, Brasília: Editora do Senado Federal, 2008. 
autores também na obra de Hemingway. No primeiro capítulo de nossa dissertação, discutimos a literatura enquanto fenômeno inseparável da atmosfera histórica na qual emerge. Contudo, parece aqui uma oportunidade de revisitar uma discussão, iniciada em Deleuze, que buscou analisar a literatura também como produtora de diferença. Entendemos que o filósofo francês contribui para nosso debate ao apresentar operações através das quais a literatura extravasa os limites socialmente impostos pela estética e linguagem.

Luiz Costa Lima, em Mimesis: desafio ao pensamento, desenvolve um $\operatorname{argumento}^{48}$ contra Deleuze, mas sabe preservar o valor de suas reflexões. Para esse crítico brasileiro, as considerações deleuzianas sobre o plano de imanência na literatura, em vez de abrir novos espaços de experiências, acaba por privilegiar a incompreensibilidade ao tentar abandonar a representação. Estando a representação ligada ao fenômeno mimético (que, por sua vez, depende da existência de um plano linguístico e cultural comum para que exista alguma comunicação entre a obra e seu leitor), a conclusão lógica é que abandonar a identidade em nome da diferença seria um tiro do pé para o estudo literário, porque privilegiaria aquelas obras que, incomunicáveis, podem sempre ser reduzidas a mero adorno.

Essa alergia deleuziana pela identidade tentou ser explicada e corrigida por Costa Lima na releitura do conceito de mimese, cuja natureza ultrapassaria a noção de cópia ou imitação. Quando Deleuze toma parte de um tipo específico de autores que, segundo ele, produzem literatura menor - isto é, os russos e os estadunidenses, - ele apenas substitui um tipo de representação por outra, segundo Costa Lima ${ }^{49}$. Não parece proveitoso para nossa dissertação ingressar nessa discussão, ainda que ela seja proveitosa para nosso objeto. Acreditamos, contudo, que seja possível uma outra análise a partir de certos conceitos de Gilles Deleuze - isto é, uma que não privilegie o incompreensível, mas que busque aquilo que extravasa a análise dialética.

Acreditamos que o melhor caminho seja mostrar como a obra de Hemingway, apesar da relativa proximidade que o autor teve com a mais

48 COSTA LIMA, Luiz. Mimesis: desafio ao pensamento. Rio de Janeiro: Civilização Brasileira, 2000.

49 Sobre a discussão, ver o sexto capítulo de COSTA LIMA, Luiz. op. cit., 2000. 
elaborada estética literária de seu tempo (bom lembrar que era - ao menos se considerava - amigo de James Joyce) e trilha um caminho próprio na linguagem. Assim, a literatura de Hemingway foge à vanguarda, mas foge também à imitação do cânone, criando uma forma narrativa quase particular. Recorrer ao elogio de Deleuze aos autores que puderam escrever numa língua menor (que não significa uma língua incompreensível, mas uma "traição" da língua oficial/formal), na análise de Hemingway, é uma tentativa de aproveitar o conceito deleuziano, sem termos de aderir inteiramente às suas teses.

Vale ainda ressaltar que muito do que Deleuze escreveu sobre literatura norte-americana já havia aparecido em análises, ainda nos anos 1950, sobre o próprio Ernest Hemingway. Dois ensaístas estadunidenses, Harry Levin ${ }^{50}$ e Carlos Baker $^{51}$ (o último tornou-se seu biógrafo mais importante), produziram críticas literárias sobre o autor, tendo em vista as possibilidades de comparar suas formas narrativas com a produção de imagens. Para Baker, tratava-se da produção de uma literatura que alterava as formas ver, que trabalhava na oposição entre o dito e o não dito, uma espécie de jogo de luz e sombra ${ }^{52}$.

Podemos aproximar a noção de superficialidade, tal qual ela aparece em Deleuze, com aquilo que Harry Levin identificou como a aproximação radical entre leitor e narrador, que "escolhe as palavras para nos agarrar e transferir-nos ${ }^{53}$ " para a experiência narrada. Também ele vai dizer que esse "agarrar e transferir" acelera o ritmo do romance, o que leva Harry Levin a recorrer à imagem do filme cinematográfico. O que não quer dizer que os textos de Hemingway possam ser transplantados diretamente para um estudo como se fossem o roteiro de um filme, mas que as imagens literárias que essa literatura produz estão mais próximas daquilo que Deleuze chamou de imagem-movimento ${ }^{54}$ do que da composição de um quadro pintado. Vale aqui citar um trecho da análise de Levin:

A prosa fica o mais perto possível do conflito físico (...). Cada sentença emendada, cada frase preposicional, é como um novo frame

50 Observations on the Style of Ernest Hemingway, The Kenyon Review, v. 13, n. 4 (Autumn, 1951), p. 581-609.

51 BAKER, Carlos. Hemingway: o escritor como artista. Rio de Janeiro: Civilização Brasileira, 1974.

52 Idem, Ibidem.

53 Tradução minha de: "he chooses his words to grip and transfix us" (LEVIN, op. cit., p. 599).

54 DELEUZE, Gilles. Cinema 1 - a imagem-movimento. São Paulo: Editora 34, 2018. 
numa fita de filme; de fato, toda a passagem, como tantas outras, poderia ter sido filmada pela câmera e projetada na tela ${ }^{55}$.

A produção de uma literatura que se aproxima da imagem-movimento do cinema é um dos pontos que queremos destacar da sensibilidade de Hemingway. Além disso, a aceleração decorrida dessa proximidade entre leitor-experiência narrada será crucial para futuras gerações de escritores norte-americanos, como Jack Kerouac. Harry Levin, prevendo a influência que Hemingway teria nas letras de língua inglesa, exagerou um lugar privilegiado para o autor, ainda em 1951:

Hemingway é o contemporâneo mais novo de Proust e Joyce. Ainda que seu tempo não seja nem le temps perdu nem o passado nostalgicamente recuperado, ele passa-o colhendo flores enquanto pode, para o sempre-acelerado ritmo das manchetes e telegramas e alto-falantes. $\mathrm{O}$ ato, assim que feito, é dito, tornando-se simultâneo com a palavra, antes dito que sentido ${ }^{56}$.

$\mathrm{O}$ fato de que esse crítico tenha recorrido às imagens de "manchetes, telegramas e alto-falantes" para explicitar a velocidade da narrativa de Hemingway é significativo, pois, assim, existe uma aproximação entre ela e aquele processo de transformação da vida nas cidades, impulsionado nas primeiras décadas do século XX. O movimento que vai das "flores" às "manchetes, telegramas e alto-falantes" não deixa de ser também uma analogia à trajetória que leva o próprio Hemingway de Oak Park até Paris, nos anos 1920.

As funções que muitas oposições vão operar na sua literatura, como aquelas entre humano x natural; interior x metrópole; noite $\mathrm{x}$ dia, não são apenas conteúdos, mas formas de organizar a linguagem. Na grande cidade, cercado de pessoas, automóveis, prédios, música, os personagens tagarelam, mentem, são desonestos e cruéis. Na natureza, a linguagem pode ser irônica, mas vai em direção à verdade.

55 Tradução minha de: "Prose gets as near as it can to physical conflict (...). Each clipped sentence, each prepositional phrase, is like a new frame in a strip of film; indeed the whole passage, like so many others, might have been filmed by the camera and projected on the screen." (Idem, Ibidem, p. 601).

56 "Hemingway is the younger contemporary of Proust and Joyce. Though his time is neither Ic temps perdut nor the past nostalgically recaptured, he spends it gathering roscs while he can, to the ever-accelerating rhythm of headlines and telegrams and loud-speakers. The act, no sooner done than said, becomes simultaneous with the word, no sooner said than felt". (Idem, Ibidem, p. 602). 
$\mathrm{O}$ fato de que as imagens literárias de Hemingway se assemelhem aos frames cinematográficos nos leva a considerar outra característica importante: sua condição fragmentária. Seria necessário, então, colocar a relação entre todo e parte numa espécie de inversão, ou seja, priorizando não as partes do todo, mas a forma pela qual é possível ler a literatura de Hemingway como composta por fragmentos. Como disse Deleuze: "os americanos, ao contrário [dos europeus], têm um senso natural do fragmentário (...). O próprio da América não é, portanto, o fragmentário, mas a espontaneidade do fragmentário" ${ }^{97}$.

Mais complicado, porém, é identificar essa fragmentariedade, de forma clara, dentro desse grande bloco ao qual Deleuze faz referência. Nossa dissertação tem a vantagem de lidar com apenas um autor. E, de fato, na obra de Hemingway, é possível partir de certos elementos recorrentes que indicam a fragmentariedade, estando ausente o que ficou conhecido como a composição de estruturas do romance realista ${ }^{58}$.

Em Hemingway, seria preciso imaginar uma espécie de realismo fragmentário, no sentido de que a realidade que sua literatura representa esteticamente não tem nenhuma estrutura social ou composição a partir de valores morais. Os romances se iniciam com personagens já em meio à ação, e o leitor recebe muito pouco deles, até que algum evento irrompe dentro da narrativa para arrancar deles uma decisão. Ainda assim, o conhecimento adquirido por parte do leitor a respeito dos personagens e de suas memórias é incerto. O texto, depois da apresentação de um personagem, joga a narrativa numa espiral de situações que indicam a possibilidade de uma contrainterpretação. Daí que seja possível ler aquele efeito destacado por Levin como uma via de mão dupla: ao mesmo tempo em que aproxima o leitor da experiência narrada, a proximidade barra a possibilidade de uma visão que supere às limitações do protagonista.

Isso mostra um afastamento de Hemingway em relação ao romance realista do século XIX (Flaubert, Stendhal ou Balzac), tradição que conheceu bem durante sua passagem em Paris. A obra de Hemingway não constrói estruturas, e seus personagens não têm nada de tipos sociológicos. Mesmo uma investigação histórica ou sociológica dos tipos sociais trazidos para a narrativa acabaria por

57 DELEUZE, Gilles. op. cit., 1997, p. 67. 58 BARTHES, Roland. 
apresentá-los em contradição com essas identidades socialmente construídas, uma vez que a particularização é um elemento constitutivo da sua literatura. Se pensarmos, por exemplo, em Pedro Romero, uma investigação sobre a posição do toureiro na sociedade europeia ou de sua figura nas representações estéticas no período estariam ainda longe de esgotar o personagem. Apontado no romance como o melhor toureiro da Espanha, sua função não é representar de forma mais adequada o "tipo toureiro" (ele mesmo afirma que não deveria deixar que outros personagens soubessem que ele entende inglês, pois não ficaria bem para um toureiro espanhol). É justamente pela forma extremamente particular com que Romero arrisca sua vida, algo que, diz o narrador de O Sol Também Se Levanta, "ninguém é capaz de imitar".

Se não há uma estrutura social claramente apresentada, isso permite que Hemingway construa narrativas em que todos os personagens (mesmo aqueles pertencentes às classes altas) sejam - ou, ao menos, sintam-se como - figuras marginalizadas. Em O Sol Também Se Levanta (1926), por exemplo, as classes sociais têm papel ambíguo: não perderam totalmente sua representação, mas elas não têm efetividade nem para organizar as interações entre os personagens, nem para a compreensão deles individualmente (o que resulta numa espécie de paródia sociológica, cujo exemplo mais claro e irônico é o título de nobreza de Brett Ashley, de origem tão obscura quanto o título do Conde Mippopopolous, seu amante grego por algumas páginas). O resto do corpo de personagens principais é constituído por burgueses desocupados, pouco talentosos demais para serem escritores e artistas (que é, aliás, como são reconhecidos pelos outros personagens), mas confortáveis demais para terem que trabalhar. Trabalhadores mesmo só aparecem nesse romance durante a madrugada parisiense, arrumando as mesas e cadeiras, nas quais esses herdeiros expatriados se sentam, ou durante os preparativos para a fiesta, na cidade de Pamplona.

Mesmo num romance marcadamente político, como Por Quem os Sinos Dobram, a organização de guerrilheiros é completamente inorgânica, sendo o grupo mais um remendo de fragmentos do que corpo político organizado e armado. Esses personagens não possuem nacionalidade definida, misturando 
ciganos, bascos, espanhóis, americanos e russos. Eles não sabem bem o que vão fazer e como devem operar nos combates, além disso, apesar de serem - ou se dizerem - antifascistas, são tão diferentes entre si (seja em termos de valores morais, como em coragem, técnica, habilidades físicas, estabilidade emocional, desejos e expectativas) que a única coisa que parece mantê-los unidos é a atuação de Jordan (o que, tampouco, significa que o protagonista é mais estruturado.

\subsection{Superficialidade}

Como vimos acima, superficialidade e fragmentariedade são dois elementos que se potencializam na obra de Hemingway. Sobre a noção de superficialidade em literatura, existe uma discussão na obra de Erich Auerbach que vale a pena revisitar, a fim de entender melhor o que queremos dizer ao nomear a narrativa heminguiana de "superficial". Além disso, recorrendo, no primeiro momento, a Gilles Deleuze, no segundo, a Erich Auerbach, busca-se uma tentativa de contribuir para o problema levantado por Costa Lima em sua crítica ao primeiro. Desejamos mostrar aqui como, ao tomar em conjunto as duas análises, é possível obter mais do objeto literário do que recorrendo a uma única vertente do pensamento.

No ensaio A cicatriz de Ulisses, que abre o livro Mimesis (1946), se definem dois arquétipos narrativos que dão origem à história da literatura ocidental: o verso homérico e o texto judaico do Velho Testamento. O primeiro é definido como claro e direto, sua narrativa cobre inteiramente as ações, intenções e os sentimentos dos personagens. Os versos atravessam a totalidade dos objetos dispostos nas ações narradas, operando sempre em primeiro plano. Esse é o estilo que pode ser definido como superficial. Essa superficialidade não possui caráter negativo e só pode ser plenamente entendida em contraponto ao segundo arquétipo narrativo, o texto judaico.

Nele, há pouca definição quanto ao tempo ou ao espaço das ações, e a narração revela apenas os traços principais do que acontece, de modo que é sempre necessária uma interpretação para que se possa entender o texto. Ao fazêlo, atravessa, por meio, também, de seus personagens, zonas sombrias, como se o 
próprio texto exigisse do leitor um intérprete ${ }^{59}$. Enquanto os personagens de Homero são superficiais, seus sentimentos e o sentido de suas ações estão abertos para o leitor ou ouvinte, já os do Velho Testamento são compostos de camadas, cujo acesso é sempre difícil e conflitivo: há sempre um segundo plano, onde mora a verdade, dotando a superfície de caráter de mera aparência; daí a exigência de uma interpretação. $\mathrm{O}$ verso homérico, ao contrário, só pode ser descrito e não interpretado ${ }^{60}$.

Portanto, a oposição superficial $x$ profundo se localiza já em um dos berços da literatura ocidental. Saltando para os ensaios do filólogo sobre literatura moderna, reconheceremos que essa oposição continuou relevante na Idade Moderna, mas principalmente a partir do século XVIII. O período entre essas literaturas também é fértil de análises auerbachianas, porém não poderemos ingressar nelas nesse momento ${ }^{61}$, interessa apenas dizer que ele é marcado por uma dupla crise de perda de sentido: intra e extramundano. Para a literatura, isso vai significar algo como um retorno àquela superficialidade. Investiguemos aqui brevemente como Auerbach entende esse processo:

Em Sobre o lugar histórico de Rousseau, o autor ressalta que:

\begin{abstract}
a descristianização significou igualmente uma desdramatização dos eventos terrenos, que agora se transformaram em curso meramente mundano das coisas e portanto, como logo se fez ver, em algo muito mais fluente, natural e livre do medo. A mentalidade mundana do homem iluminista não indica primariamente uma adesão mais forte e intensa ao mundo terreno - supô-lo seria um grave erro. Com a abolição do além, também outro polo, o aqui, perde muito de sua força. O século iluminista não é pobre apenas em profundidade espiritual, mas também em sensibilidade intramundana; no sentido autêntico da palavra, ele é "superficial"
\end{abstract}

Vemos, portanto, que o argumento de Auerbach para a crise que se inicia na Idade Moderna dá continuidade àquela posição tomada no ensaio sobre Ulisses, no qual propõe a oposição "superficialidade do verso homérico" versus "profundidade do texto judaico-cristão": não poderia ser diferente, portanto, quando a literatura iluminista, recorrendo diretamente às fontes literárias da 59 AUERBACH, Erich. Mimesis: a representação da realidade na literatura ocidental. São Paulo: Perspectiva, 1971. 60 Idem, Ibidem.

61 A referência feita aqui é aos ensaios de Auerbach sobre Dante, por exemplo, em AUERBACH,

Erich. Dante: poeta do mundo secular. 62 Idem. Ensaios de Literatura Ocidental. São Paulo: Editora 34, 2020. 
Antiguidade, torna-se ela mesma superficial. A "insensibilidade" comentada pelo autor está diretamente relacionada ao fato de que, uma vez abandonada a ideia de um mundo para além deste, desaparece a necessidade de uma interpretação minuciosa, de penetrar nas camadas submersas por baixo da superfície, já que essas deixaram de existir.

A visão de mundo e a literatura cristãs, para o autor, operavam segundo a "moldura" estruturada pelo Velho Testamento, um conjunto de textos que

fornece história universal; começa com o princípio dos tempos e, com a criação do mundo, e quer acabar com o fim dos tempos, com o cumprimento da promessa, com a qual o mundo deverá encontrar seu fim. Tudo o mais, que ainda acontece no mundo, só pode ser apresentado como membro desta estrutura ${ }^{63}$.

O processo de "descristianização" do Ocidente é a perda dessa moldura, o que tem efeito direto para a literatura. Para o drama medieval cristão, diz Auerbach que:

\begin{abstract}
A unidade estava encarnada na história do mundo e da salvação, desde Adão até Jesus e o Juízo Final. Estava sempre presente no espírito do espectador e, acima de tudo, the era sempre comunicada pela organização do palco. Qualquer lugar, qualquer época, qualquer objeto, qualquer nível do estilo ajustavam-se a sua moldura abrangente. Só quando esta moldura se perdeu, quando deixou de haver um povo cristão e uma visão cristã homogênea do mundo, foi que se tornou necessário preocupar-se com a unidade ${ }^{64}$.
\end{abstract}

Certamente, o processo histórico de reconstrução da citada "unidade" através da literatura e das artes no Ocidente é complexo e não se pretende cobri-lo aqui. Parece-nos, no entanto, que nem mesmo um autor do século $\mathrm{XX}$, como Ernest Hemingway, pode escapar a essa discussão. Afinal, se queremos identificar como esse escritor elaborou sua literatura nas superfícies do texto, isso significa dizer que não há, como diz Auerbach sobre Homero, a possibilidade de interpretálo, somente de analisá-lo. Isso é importante, porque nos permite largar mão de uma grande quantidade de interpretações "profundas" da obra de Hemingway ${ }^{65}$.

63 AUERBACH, Erich. op. cit., 1971, p. 13.

64 Idem, op. cit., 2020, p. 243.

65 A fortuna crítica heminguiana, quase toda em inglês, oferece muitas dessas leituras interpretativas. Essas mesmas leituras variam de acordo com a teoria literária ou filosofia hegemônica do período; há leituras simbolistas (HALLIDAY, 1951), existencialistas (BARRET, 1997) e até cristãs de Hemingway (BLOOM, 2011). Nesta dissertação, resolvemos descartar todas elas, uma vez que partimos do princípio de que sua literatura não perseguiu verdades ocultas, mas a verdade no aparente. 
Mais um salto na leitura de Auerbach, até o momento em que se analisa a emergência do romance realista do século XIX e o romance modernista do século XX. Em Na mansão de La Mole ${ }^{66}$, o filólogo analisa a transição desse período de "crise da moldura" para a forma do romance realista moderno. Este último, segundo Auerbach, tem sua forma narrativa finalmente definida em Gustave Flaubert - cuja importância não foi pequena para a formação de Ernest Hemingway. Mas não existiu, em Hemingway, um projeto teórico, a chamada "teoria" do iceberg (ele foi extremamente adverso à manifestação de suas próprias teorizações, principalmente sobre seus próprios textos). Existe, contudo, aquilo que Hemingway chamou de princípio do iceberg ${ }^{67}$, que nada mais é do que fazer emergir todo um bloco de sensações a partir da descrição de uma pequena parte superficial.

Daí que a leitura deleuziana nos pareça fundamental, principalmente o seu comentário sobre a operação da dissociação entre objeto e sua imagem em Lewis Carroll $^{68}$. Aqui, o filósofo faz referência à passagem de Alice no País das Maravilhas (1865), na qual o sorriso do Gato salta do próprio personagem, restando, por fim, apenas o próprio brilho que salta ao próprio sorriso. Evidentemente, para Deleuze, esse movimento não cria profundidade ao texto, mas sim promove a superposição de superfícies (Deleuze chama o autor de Alice no País das Maravilhas de "Carroll fotógrafo").

O movimento de aplainamento da imagem literária em Ernest Hemingway é também encontrado, de forma exemplar, numa passagem que descreve o olhar de Brett Ashley. A personagem e o narrador estão sentados no banco de trás de um automóvel, rodando pelas ruas de Paris, durante uma noite. As sucessivas imagens literárias vão sendo descritas como se acompanhassem o movimento do carro e a sucessiva entrada e saída de luz dentro do automóvel, até que Barnes é capturado pelo olhar de Brett:

Brett me olhava bem nos olhos, com aquele seu jeito que nos fazia duvidar de que via realmente com seus próprios olhos. E os olhos dela continuariam a olhar, depois que todos os olhos do mundo tivessem cessado de olhar. Olhava como se nada existisse na Terra que não

66 AUERBACH, Erich. op. cit., 1971.

67 HEMINGWAY, Ernest. The art of ficction, n. 21. The Paris Review, 1958.

68 DELEUZE, Gilles. op. cit., 1997, p. 31-33. 
tivesse ousado olhar assim e, na verdade, tinha medo de tantas coisas $!^{69}$

Em momento algum, há profundidade nessa descrição; o narrador é incapaz de penetrar no objeto que, ao saltar, constitui, ele mesmo, um instrumento de autoproteção. Como em várias outras passagens do autor, o narrador não atravessa a superfície que descreve, não há descoberta de quaisquer camadas por baixo das aparências. Hans Gumbrecht, em Produção de Presença, comenta o destino que noções de "superficialidade", como aquela de "corpo", encontraram na história da metafísica ocidental. Em uma trajetória de exclusão progressiva, o corpo é afastado da alma e da superfície da profundidade, de modo que o pensamento filosófico moderno valorize aquilo que aparenta incorporeidade e profundidade $^{70}$. Como Gumbrecht, acreditamos na possibilidade de ler manifestações literárias de uma outra maneira, priorizando maneiras mais corpóreas e superficiais.

\subsection{Menoridade}

Um dos efeitos mais importantes, em termos de leitura, do que chamamos de fragmentariedade e superficialidade, na obra de Hemingway, talvez seja o fato de que não temos um acesso privilegiado à narrativa ou aos personagens. Nem narrador, nem protagonista são dotados de natureza moral superior, nem de percepções mais agudas e acuradas do mundo, ou de uma consciência maior do sentido de suas ações. Como o leitor, o narrador e o protagonista tateiam o solo da narrativa, mas ninguém sabe o que se passa por debaixo das superfícies. Não conhecemos melhor os personagens do que eles conhecem a si mesmos e aos outros, contudo, uma decisão pode alterar completamente todos os julgamentos prévios. Em O Sol Também Se Levanta, a condição patética de Robert Cohn não é um segredo nem para ele mesmo; não se trata de uma constatação privilegiada por

69 HEMINGWAY, Ernest. O Sol Também Se Levanta. Rio de Janeiro: Bertrand Brasil, 2014. 70 GUMBRECHT, Hans Ulrich. Metafisica: breve pré-história do que está mudando em $A$ Produção de Presença. Trad. Ana Isabel Soares. Rio de Janeiro: Contraponto/Editora PUC-Rio, 2010. 
parte do narrador. A perversidade de Brett Ashley é um fato conhecido e comentado por todos os personagens.

Ainda que tenha obtido sucesso comercial durante praticamente toda sua vida, é possível dizer que Hemingway produziu algo como uma literatura menor em sua obra. Tanto nos contos quanto nos romances, existe uma tendência à fragmentação do herói, ao esvaziamento dos valores, à negação de outras subjetividades não normativas, recorrendo subjetivamente a figuras femininas ${ }^{71}$, indígenas, infantis e animais.

Mesmo nos protagonistas, muitos deles, homens adultos, veteranos de guerra, percebemos que há algo como uma menoridade neles. Robert Jordan, Frederic Henry ou Jacob Barnes são construídos mais por seus conflitos internos e pela dificuldade que têm de lidar com a coexistência de seus fragmentos do que por uma identidade social específica. Eles, contudo, também são muito diferentes dos protagonistas dos romances de formação (Bildungsroman), cuja mudança interna se dá sempre dialogicamente com o mundo externo. É na velocidade de um frame, como Levin identificou na descrição das ações, que esses protagonistas são invadidos por temores, memórias, medos, ainda que tudo possa mudar rapidamente para uma tranquilidade ribeirinha, como a de Nick Adams em Big Two-Hearted River.

Eles chegam "prontos", o que também não significa a prontidão de um herói já feito, como Aquiles ou Ulisses; essa é, ao contrário, uma prontidão propriamente fragmentária. Jordan, Henry e Barnes (para não citar agora também aqueles personagens dos contos, nos quais a tendência é ainda mais visível) são personagens fragmentados internamente, o que, muitas vezes, se traduz numa fragmentariedade corporal. Em Barnes, a dualidade entre a fragmentariedade interna (emocional, sensível) e a externa (mutilação total ou parcial das capacidades sexuais) é levada ao ponto mais claro em toda a literatura heminguiana.

Esses personagens, no entanto, são também marcados pela banalidade, fragilidade e efemeridade: têm sonhos mesquinhos, da pequena burguesia, de

71 Abertura que dá margem a alguns estudos interessantes sobre o transgênero em Hemingway, como em Rohy, Valerie. Hemingway, Literalism, and Transgender Reading. Twentieth Century Literature, v. 57, n. 2, 2011, p. 148-179. 
pequena-intelectualidade, são, por vezes, alcoólatras e, quase sempre, medrosos mesmo que sejam guerrilheiros, que tenham lutado na guerra contra as forças de Francisco Franco. Sua única característica "engradecedora" é a possibilidade de se tornarem conscientes dessa menoridade que lhes é própria. Quando a imagem que a maioria dos personagens que os cercam têm deles é grandiosa internamente, tudo vai mal com eles. Somente ao se depararem com aqueles que veem através daquilo que não são, ou seja, quando os veem pequenos (frágeis à morte, à decepção amorosa, etc.) é que esses protagonistas encontram seus pares ideais. Em Jordan, o amor que guarda por Maria nunca poderia ser comparado ao respeito que foi construído por Pilar (que previu a derrota de sua missão e, consequentemente, sua morte iminente); para Henry, apaixonar-se por Barkley foi natural depois que ela percebeu que ele é apenas um rapaz que joga um rooted game. Por mais que Hemingway o torne consciente disso, Barnes não pôde deixar de ser um escravo de Ashley. Enquanto leitores, somos arrastados, junto com os protagonistas, até a evidência de sua pequenez: aprendemos sobre ela em conjunto com eles e, juntamente, a sofremos.

Outra questão relativa à menoridade desses personagens é sua incapacidade de agir de forma grandiosa. Hemingway tratou de deixar isso bem claro: os sonhos e objetivos desses personagens não são grandiosos e, talvez, isso seja ainda mais relevante, uma vez que as frustrações provenientes dos seus fracassos não lhes ensinam nada. No romance de formação (Bildungsroman), se pode esperar que, mesmo que o protagonista não ganhe nada daquilo que se propõe a tentar, ao final, ele ganhará a si mesmo: uma versão maior de si mesmo. No romance heminguiano, não há nada disso. Primeiramente, os sonhos, desejos e objetivos desses três protagonistas são relativamente simplórios: Jordan quer explodir uma ponte e não morrer tentando; Henry quer juntar-se com uma mulher que o despreza de forma mais ou menos explícita e Barnes deseja apenas pescar na Espanha, durante o verão. Contudo, nem esses "ideais", nem os objetivos secundários de todos os personagens de todos esses romances jamais têm desfecho idêntico àquele planejado. Em Hemingway, "nunca se faz aquilo que se quer" (Adeus às Armas). 
Os personagens, principalmente os marginais, entram numa estranha condição que podemos chamar de dupla consciência da personagem. Primeiramente, eles são personagens realmente atuantes nas narrativas, mas, em segundo lugar, esses personagens sofrem as condições impostas pela menoridade do romance heminguiano. Robert Cohn sofre sua condição de personagem patético, ainda que todas as suas ações pudessem - caso O Sol Também Se Levanta não fosse um romance menor - fazê-lo também um personagem tradicional do romance realista clássico. No limite da esquizofrenia e da paranoia, Robert Jordan sofrerá a necessidade de ser um herói clássico - aquele que cumpre seu destino, como que incentivado pela palavra e ação dos deuses -em face da realidade de ser apenas um herói menor. Sua morte, inevitável ou não, é, muito provavelmente, tão insignificante quanto sua vida para a totalidade da Guerra Civil Espanhola, que cerca toda a narrativa de Por Quem os Sinos Dobram. Que ele tenha consciência dela não torna o resultado mais heroico; sua decisão de morrer numa batalha por uma causa evidentemente justa (a luta contra o fascismo, pela liberdade de qualquer povo) traduz-se na sua subjetividade como "morrer num buraco no interior da Espanha com outras cinco pessoas, que conheci três dias atrás". Mesmo seu objetivo mais simples, mais reduzido (explodir uma ponte) não possui qualquer garantia de: a) sucesso, por mais capazes, preparadas e calculadas que sejam as ações de Robert Jordan; b) relevância, uma vez que sua missão é menos que uma gota no oceano que é a Guerra Civil Espanhola. Estar consciente de sua menoridade, de sua nulidade e da nulidade de suas ações: essa é a consequência de ser um protagonista num romance heminguiano.

Como foi comentado, não há lugar onde essa condição se evidencie mais claramente do que nos contos de Hemingway. Não por acaso, neles domina, bem mais que os personagens, o ambiente. Seja com beleza, seja com decadência, é sempre uma natureza esmagadora que suprime a subjetividade do protagonista/narrador. Esses lugares podem até ter nomes, mas poderiam ser mais bem descritos como lugar nenhum: no escuro e abandonado interior do Michigan, no sufocante e banal interior do Oklahoma, em algum porto qualquer, infestado pela guerra, na Turquia ou numa estação de trem perdida em algum lugar da África, a menoridade ambiental esmaga o conto heminguiano com força. 
Qualquer ação, em qualquer desses lugares, - por mais que pudesse apresentar um aspecto moralizante (fala-se de estupro, aborto, assassinato e incesto), - quaisquer decisões ou ações tomadas não têm nenhuma consequência sob um ponto de vista mais largo. 


\section{O Sol Também Se Levanta e a realidade fragmentada}

\section{1 - Introdução}

Quando estudou o ano de 1926, Hans Ulrich Gumbrecht, argumentou que sua escolha se devera justamente à pouca importância que aquele ano tem sob o ponto de vista histórico. Tal "desvantagem" converte-se, contudo, na abertura de novas pesquisas, uma vez que não mobiliza nenhum dos grandes eventos da história recente para justificar a legitimidade de seu objeto enquanto fonte de pesquisa histórica. Gumbrecht mostrou como é aplicar um olhar histórico nos fragmentos dispersos presentes no cotidiano de um determinado tempo e, a partir deles, construir uma narrativa. É possível ver nossa tentativa de ler O Sol Também Se Levanta de maneira análoga; esse romance não se insere na história da literatura do século XX como ponto alto de nenhum movimento estético, não aparece como modelo para as próximas gerações de escritores, de forma que (se quisermos ir mais longe em nossa analogia), podemos dizer que $O$ Sol Também Se Levanta é compatível com o ano no qual foi publicado: justamente, o ano de 1926.

Não é um romance atravessado pela reflexão filosófica, não tem intenções de fundar uma nova estética ou de fazer parte das grandes obras da literatura ocidental. Seria mais bem descrito como um romance superficial, conforme tentamos mostrar no último capítulo. Tal superficialidade narrativa, assim como a banalidade da vida de seus personagens, pareceram-nos, elas mesmas, objetos de uma reflexão histórica interessante, porque capaz de acesso a um tipo de sensibilidade estética que se desenvolveu entre romancistas dos anos 1920.

Se o início do século XX foi marcado por movimentos culturais de ruptura radical com o passado, assim como pela crença de que, terminada a guerra de 1914-1918, seria necessário que os escritores refizessem todos os paradigmas estéticos e criassem uma nova literatura ${ }^{72}$, um livro como O Sol Também Se Levanta, não poderia estar à margem dessas discussões. O modernismo estético nasce e potencializa as transformações trazidas pela consolidação da hegemonia

72 Sobre o fim da Primeira Guerra e a necessidade de uma nova estética, ver SCHÖNPFLUG, Daniel. Era do cometa. São Paulo: Todavia, 2019. 
da vida metropolitana no Ocidente, assim como dá forma estética à aceleração das temporalidades cotidianas e às rupturas morais decorridas dessa transformação, como tentamos mostrar no primeiro capítulo.

A obra de Ernest Hemingway voltou-se para o seu tempo presente e nele encontrou uma sociedade fragmentada, não apenas pela Primeira Guerra, mas também por processos ainda em curso. Vimos, a partir das análises de Walter Benjamin, Marshall Berman e Modris Eksteins, como Charles Baudelaire fora o principal estruturador poético das transformações estéticas e sociais ocorridas desde a metade do século XIX ${ }^{73}$.

Longe de querer atribuir a Ernest Hemingway o mesmo peso enquanto produtor de uma nova estética, podemos dizer que sua função enquanto escritor é similar: O Sol Também Se Levanta aparece como uma tentativa de captar a realidade imediata assim como o escritor consegue captá-la, de modo que podemos lembrar da figura que Baudelaire tece para o pintor moderno, que desenha nas madrugadas o que viu durante o $\mathrm{dia}^{74}$. Portanto, se a forma pela qual essa realidade aparece no romance é fragmentária, isso nos faz crer que há algo como uma fragmentação presente, não apenas na percepção desse escritor, mas também nessa própria realidade observada. As imagens breves, frases curtas e objetivas, o tipo de linguagem empregada - que não dispensa os palavrões, em espanhol e inglês, mais chulos - e a condução dos personagens, a proximidade entre narrador e autor, são todos elementos fundamentais para que $O$ Sol Também Se Levanta seja uma narrativa composta por estilhaços e fragmentos.

Hemingway não tinha em mente qualquer sistema filosófico ao escrever esse romance, ele também não parecia muito preocupado em adequá-lo ao que havia de mais recente em literatura. Há uma relação interessante entre Hemingway e a pintura modernista à qual ele mesmo faz referência em entrevista concedida à revista Paris Review ${ }^{75}$ - dando destaque às suas tardes de estudo dos quadros de Cézanne ${ }^{76}$.No entanto, como se poderá ver no decorrer deste capítulo,

73 Pouco pudemos discutir a obra de Dolf Oehler, mas é nela que encontramos a leitura mais interessante de Baudelaire; ver OEHLER, Dolf. Quadros Parisienses: estética antiburguesa (1830-1848). São Paulo: Companhia das Letras, 1997.

74 BAUDELAIRE, Charles. O pintor da vida moderna em Sobre a modernidade. São Paulo: Paz e Terra, 1996.

75 HEMINGWAY, Ernest. op. cit., 1958.

76 Sobre a relação entre Hemingway e Cézanne, ver WATTS, Emily Stipes. Ernest Hemingway and the Arts. Champaing: University of Illinois Press, 1971; e GAILLARD, Theodore L. 
queremos propor uma relação possível também com o cinema. Isso não significa dizer que seus romances funcionem também como roteiros, mas sim que as imagens literárias produzidas neles estão mais próximas daquilo que Gilles Deleuze chama de imagem-movimento do cinema $^{77}$ do que das imagens literárias identificadas na tradição do romance realista do século XIX, por exemplo. Junto à aceleração das formas de trabalho, dos meios de transporte e de toda vida cotidiana, a aceleração da narrativa acompanha os processos indicados desde o fim do século XIX/início do século XX.

\section{2 - Paris}

O romance começa apresentando um dos personagens principais da trama narrativa, Robert Cohn, que pode ser descrito como um entediado filho da burguesia estadunidense. As páginas de apresentação são relevantes, pois revelam características do personagem que o marcarão durante toda a narrativa. No momento em que sua descrição termina, o leitor percebe Cohn como alguém entediado com a própria condição privilegiada, malsucedido nas suas anteriores tentativas de "escapar de si mesmo", primeiro, através do esporte, da arte, nas aventuras e, finalmente, no amor.

Dirá o narrador que Cohn ingressa no boxe "apenas para compensar o complexo de inferioridade e a timidez que sentira, porque o tratavam como judeu, em Princeton ${ }^{78}$ ". No entanto, mesmo o estigma não lhe é marcante, o que interessa na construção desse personagem é, portanto, sua função dentro do romance, que é o seu apagamento. O narrador diz sobre ele: "Nunca conheci um só colega que se lembrasse dele", ainda assim, Cohn é quase onipresente; é sempre preciso lembrar quando não está presente, assim como acertá-lo com ofensas quando está. Tornase, desse modo, um personagem extremamente importante para a composição da narrativa e da constituição dos outros personagens.

Ele é "agarrado" por uma mulher, tem filhos com ela e resolve abrir uma revista de artes, mesmo que não possuísse qualquer ligação com o mundo artístico

Hemingway's Debt to Cézanne: New Perspectives. Twentieth Century Literature, v. 45, n. 1, 1999, pp. 65-78.

77 DELEUZE, Gilles. Cinema 1 - a imagem-movimento. São Paulo: Editora 34, 2018.

78 HEMINGWAY, Ernest. O Sol Também Se Levanta. Bertrand Brasil, 2015, p. 9. 
(ao menos, isso não aparece em momento algum no romance). Ironicamente, sua mulher o deixa por um "pintor miniaturista". Seu projeto artístico falha nas duas costas dos Estados Unidos, e ele é novamente "capturado" por uma mulher de nome Frances. Esta última, se torna desinteressante depois de viajarem pela Europa e mudarem-se para Paris. É nesse momento que Cohn decide deixá-la. É assim que que começa propriamente a narrativa de O Sol Também Se Levanta, quando o narrador se apresenta como um dos personagens da trama, Jacob Barnes.

A presença do narrador é outra característica importante, sempre temos de percebê-lo a partir dos outros personagens e das ações que toma em conjunto com eles. No primeiro momento da narrativa, Barnes encontra Cohn no seu pior estado: dominado e amedrontado por sua companheira, esquivando-se e mentindo para ela. Contudo, isso muda, quando sabemos que Robert Cohn publica um romance de sucesso nos Estados Unidos. Isso o faz um personagem pior

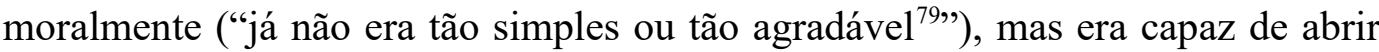
novos flancos em sua vida. É interessante que o narrador ressalte que, por começar a se imaginar e a ser tratado como um romancista, Cohn passa, então, a desejar viver como se fosse o protagonista de romance de aventuras. A primeira dessas atitudes é convidar Jacob Barnes para uma viagem de aventuras à América do Sul. Barnes lhe responde: "Você pode ver quantos sul-americanos quiser, mesmo em Paris ${ }^{80}$, , contudo, esse ou qualquer outro desejo de Robert Cohn têm pouco ou nada a ver com a realidade, mas sim com um impulso de mover-se como um personagem, de não se estabelecer em lugar algum e de não fazer nada que pareça duradouro. Numa de suas primeiras falas, resume-se bem o tipo de aflição que o constitui: "Não me conformo, quando penso que minha vida vai passando tão depressa e não a vivo realmente ${ }^{81}$ ",

No entanto, logo o leitor sabe que a ansiedade de Cohn não é apenas compreensível para os outros personagens, como é compartilhada por eles. Barnes responderá às suas preocupações de não viver realmente a própria vida: "Escute, Robert, tanto faz um país como outro. Tenho experiência disso. Não podemos sair de dentro de nós mesmos. Não adianta ${ }^{82}$. . Ao modo de Melville em Bartleby,

79 Idem, Ibidem, p. 15.

80 Idem, Ibidem, p. 16.

81 Idem, Ibidem, p. 17.

82 Idem, Ibidem, p. 18. 
Hemingway aqui encontrou uma fórmula ${ }^{83}$ que acompanha seu romance até o fim: não se pode sair de si mesmo. Toda a narrativa vai ser marcada por essa problemática, ou seja: como sair de si mesmo? Não deixa de ser uma preocupação interessante para revisitar o problema deleuziano da diferença ${ }^{84}$, na medida em que todas as lutas empreendidas pelos principais personagens são formas de tentar escapar da identidade fixada para eles pela estrutura do romance. Mesmo que suas tentativas permaneçam insatisfatórias, o ingresso de Pedro Romero (personagem com uma função muito específica e diferente do grupo principal) vem mostrar que há formas melhores para esse desejo de "escapar a si mesmo" do que aquilo que praticam Brett, Cohn ou Barnes.

Aquilo que praticam esses personagens, durante o que podemos chamar de período parisiense do romance, é como uma representação daqueles hábitos e cultura proporcionados à burguesia boêmia desde a segunda metade do século XIX. Eles circulam por bares, cafés, restaurantes, salões, galerias, estádios de jóquei e tudo o que a capital mundial da cultura tinha a oferecer. Contudo, a forma como os desejos desses personagens são mobilizados no romance indica uma espécie de esgotamento dessa cultura metropolitana, mesmo para aqueles mais imersos nela. Os personagens que acompanham o narrador são todos escritores e artistas, mas existe já um tom de autoironia nessa descrição; nenhum deles tem posição fixa na estrutura social, nenhum deles trabalha para viver. Eles são marcados por tal aura de superioridade e afetação que uma das poucas moradoras fixas de Paris, a prostituta Georgette (que, por sinal, não gosta da cidade) os reconhece à primeira vista como "escritores e artistas".

O ano de 1926 marca um momento de penetração total de Hemingway entre os maiores nomes da literatura de língua inglesa no momento. Era amigo e convivia com figuras como Scott Fitzgerald, Gertrude Stein, Erzra Pound e James Joyce. Mas haveria pouca vantagem em entender os personagens do romance como representações dessas figuras literárias, já que os personagens de Hemingway têm uma função específica dentro do romance.

Exemplo mais significativo é o de Brett Ashley, descrita a partir de diversas versões, ganhando uma identidade diferente a cada momento que alguém

83 DELEUZE, Gilles. Bartleby, ou a fórmula em Crítica e Clínica. São Paulo: Editora 34, 2011. 84 Comentado no segundo capítulo desta dissertação. 
tenta revisitar seu passado. Ela é apresentada como uma enfermeira que recebera Barnes na Inglaterra, quando voltava ferido sexualmente da Guerra na Itália. Nessa versão, eles se apaixonaram e se casaram, mas, devido à impotência de Barnes, o casamento teria afundado. Brett também é, por vezes, apresentada como "Lady" Brett Ashley, por fazer parte de algum ramo obscuro e decadente da aristocracia inglesa. De todo modo, nenhuma das descrições serve à personagem, como se apenas fragmentos dessas identidades tivessem algum sentido, uma vez que qualquer síntese das contradições apareceria como falsa. A fragmentariedade em Ashley tem relevância, porque é uma característica que não a afasta dos outros personagens, mas a torna ainda mais atraente. Brett atua como uma força de desterritorialização, que desencaixa outros personagens de seus lugares, e essa mesma potência de tornar-se objeto de desejo é revertida em movimentação: ela é capaz de arrastar os outros personagens por toda a Europa atrás dela, sem fazer quaisquer concessões ou promessas. Ela mesma não tem território fixo, tampouco ligação originária. Uma hora aparece junto a personagens sem nome, outras vezes, junto a figuras exóticas, como o conde Mippipopolous. Então, surge um personagem, que é seu noivo, Mike Campbell, contudo, ao final do romance, esse noivado não mais existe, como acontece com os casos de Brett, exceto aquele com Barnes.

Dificilmente se poderia apontar Brett Ashley como representativa de alguma figura da realidade concreta; parece mesmo que seu papel no romance é de uma função desterritorializadora. Não é por acaso que Brett ofereça participação em momentos cruciais do romance. Um desses momentos é exemplar na oferta daquilo que identificamos como uma narração através de imagensmovimento:

\footnotetext{
O táxi subiu a rua, atravessou a praça iluminada, entrou pelo escuro, subindo sempre, depois desembocou numa rua sombria em terreno plano atrás de Saint-Etienne-du-Mont, rodou suavemente no asfalto, passou diante das árvores e da estação de ônibus da Place de la Contrescarpe, fez uma volta no calçamento de pedra da Rua Mouffetard $^{85}$.
}

O narrador aqui toma a perspectiva do automóvel que o locomove, sua narração acelera e não descreve nada com detalhe. Tal questão tem importância 85 HEMINGWAY, Ernest. op. cit., p. 33. 
para o romance, as descrições não investigam profundidades, mas superficialidades, quase sempre breves. As imagens vão se intercalando, descrevendo objetos diferentes que vão emergindo na descrição à medida que o narrador se locomove pela cidade: essa é a regra para a narração em $O$ Sol Também Se Levanta. Contudo, esse olhar externo é também arrancado para o interior por Brett Ashley:

Brett me olhava bem nos olhos, com sua maneira que nos fazia
duvidar que via realmente com seus próprios olhos. E os olhos
continuariam a olhar, depois que todos os olhos do mundo tivessem
cessado de olhar. Olhava como se nada existisse na terra que não
tivesse ousado olhar assim, e, na verdade, tinha medo de tantas
coisas! $^{86}$

Aqui, por mais diferentes que pareçam os investimentos de atenção entre o primeiro momento (um olhar superficial e breve sobre a cidade de Paris) e o segundo (a captura do olhar do narrador por Brett), trata-se aqui de uma mesma forma narrativa: ela não atravessa seu objeto de contemplação. O olhar de Brett é impenetrável, constitui-se justamente com essa intenção de esconder antes de revelar. Mas essa impenetrabilidade diz tanto sobre o objeto quanto do narrador que observa, sem poder atravessar as superfícies. Mais adiante, quando Barnes atravessa a estátua do Marechal Ney, teremos mais um exemplo do tipo de olhar literário produzido no romance de Hemingway. Durante a madrugada, retornando para casa, bêbado, o narrador atravessa as ruas que o leva do último salão que visitou naquela noite até sua casa:

\begin{abstract}
Passei em frente a estátua de Ney, de pé, sob o arco de luzes, entre as castanheiras com folhas nascentes, uma fanada coroa violeta encostada ao pedestal. Parei a fim de ler a inscrição: Homenagem dos grupos bonapartistas.... Uma data que já esqueci. Tinha um ar muito distinto, com suas botas, o Marechal Ney, brandindo a espada entre a verdura nascente das folhas dos castanheiros ${ }^{87}$.
\end{abstract}

Como se vê, a atenção que o narrador investe no objeto é sempre incapaz de oferecer uma imagem fixa e complexa do objeto, trata-se de um objeto que ele “já esqueceu”. O problema entre atenção e memória nem por isso está resolvido, pois não se trata de um sujeito incapaz de lembrar, mas incapaz de esquecer.

86 Idem, Ibidem, p. 34.

87 Idem, Ibidem, p. 38. 
Somente, nesse ponto, o leitor saberá que Barnes é um ex-combatente da Primeira Guerra, no conflito sofreu um acidente que o tornou sexualmente impotente (apesar de ser impossível dizer se o ferimento tenha sido físico ou apenas emocional). Já no seu apartamento, Barnes pensa: "Minha cabeça começou a trabalhar. Sempre a mesma história. Sim, era uma forma infeliz de ser ferido ${ }^{88}$ ". As perturbações trazidas por essa condição ao narrador tendem a ficar submersas, em determinadas situações apenas, elas podem emergir. Mas, até o final, Barnes nunca poderá, de fato, elaborar a situação ou a memória do evento que lhe trouxe o ferimento. Como o próprio personagem diz: "Eu procurava não levar em conta, julgo. Fazia o possível para não incomodar ninguém. (...) Há muita gente nessas condições. Os outros que fossem para o inferno" ${ }^{" 89}$.

Não é apenas Barnes que apresenta um tipo fragmentário de atenção. O trecho que descreve um dos eventos no dia seguinte é também demonstrativo de que a condição que reconhecemos na narrativa a partir da perspectiva de Barnes é bem compartilhada também entre os outros personagens. Aqui nos referimos ao trecho que descreve o momento em que Frances, a companheira de Robert Cohn, sabendo que será deixada para que Cohn possa agora disputar a atenção de Brett Ashey com maior dedicação, decide humilhá-lo. O narrador descreverá Robert Cohn como se estivesse sob uma espécie de catatonia estratégica, que consistira em suportar todos os ataques verbais de Frances como se não estivesse ali, ou como se a conversa não tratasse dele:

\begin{abstract}
Há pessoas a quem não se pode insultar, pois nos dão a impressão de sentir que o mundo se desmoronaria imediatamente, sob nossos olhos, se lhes disséssemos certas coisas. Mas Robert Cohn permanecia ali, recebendo tudo aquilo. Tudo se passava na minha presença e eu não sentia o menor impulso de intervir.
\end{abstract}

Quanto mais tempo duravam os ataques, piores eles ficavam. Robert, então, é descrito, mais uma vez, como alguém que está tentando fazer parecer que é um herói de romances, indiferente à realidade que o cerca. Barnes pergunta-se por que razão Cohn mantinha-se lívido. "Por que permanecia assim? Por que continuava a suportar aquilo tudo ${ }^{90 \%}$. A questão, contudo, volta-se para o próprio

88 Idem, Ibidem, p. 39.

89 Idem, Ibidem.

90 Idem, Ibidem, p. 61. 
protagonista que, também, à sua maneira, aceita as formas de sofrimento que o atravessam, sem oferecer resistência ou revolta.

Com a chegada de dois novos personagens, Bill Gorton, cuja função reside numa espécie de humor dadaísta terapêutico, e Mike Campbell, o atual noivo de Brett Ashely, a narrativa ingressa num ponto de virada. Nesse ponto, os personagens deslocam-se de Paris para o interior da Espanha, na cidade de Pamplona, onde vão assistir ao festival de tauromaquia. No caminho que leva da metrópole à pequena cidade espanhola, será perceptível uma transformação na natureza da atenção que os personagens passam a investir em suas observações. $\mathrm{O}$ décimo segundo capítulo do livro é, talvez, o momento mais claro dessa transição entre o regime acelerado da metrópole e o encontro de um espaço para reflexão.

Jacob Barnes e Bill Gorton isolam-se num pequeno retiro entre a Espanha e a França, onde os personagens locais e o ambiente começam a se confundir. O narrador dirá sobre um dos personagens: "O basco que se encontrava em meus joelhos [sentados dentro do ônibus] era curtido de sol como uma sela de couro. Vestia blusa negra, como todos os outros, e seu pescoço curtido era todo enrugado ${ }^{91}$ ". É notável que, sob uma nova forma de relação entre os personagens e a natureza que os cerca, emerjam possibilidades antes impossíveis na cidade. Toda a temporalidade da pequena cidade entre a Espanha e a França parece reorganizar a percepção da realidade por parte dos personagens. O momento mais claro dessa diferença entre metrópole x natureza é quando Barnes e Gorton saem para pescar $^{92}$ : é a primeira e última vez que o protagonista é capaz de dividir algo sobre sua experiência na guerra e os sofrimentos que seu ferimento é capaz de lhe trazer.

Em nenhum outro momento do romance, a narração traz à tona um diálogo tão coberto de verdades, mesmo que sob a forma da ironia. Já um pesquisador chamara Gorton de "pregador" ${ }^{93 "}$ - ainda que um pregador-comediante - devido a sua função na narrativa, contudo, é preciso chamar atenção ao fato de que tais características do personagem são capazes de construir um solo seguro para a abertura de Barnes em meio ao ambiente ribeirinho. Uma leitura mais ampla da

91 Idem, Ibidem, p. 114.

92 Atividades como pescaria e caça têm função especial na literatura de Hemingway, como tentamos mostrar nos próximos capítulos desta dissertação.

93 ROSS, M. Bill Gorton, The Preacher in The Sun Also Rises. Modern Fiction Studies, 18(4), 1972, p. 517-527. 
obra de Hemingway confirma a função que tais ambientes desempenham em sua obra: desde os contos protagonizados por Nick Adams até a autoanálise do movimento guerrilheiro republicano por Pilar em Por Quem os Sinos Dobram (1940), são esses os mesmos tipos de ambientes revisitados para o processo de rememorização e a tomada de consciência de uma tensão até então inexplorada.

Pode-se perguntar a respeito do caminho que o diálogo assume para chegar até seu fim: afinal, os personagens atravessam, numa ironização no estilo dadaísta, figuras icônicas da história norte-americana: "Abraham Lincoln era efeminado. Estava apaixonado pelo General Grant. Jefferson também. Lincoln libertou os escravos devido a uma aposta" ${ }^{94}$. É claro que o movimento da ironia se direciona também contra o próprio Barnes: "Você é um expatriado. Perdeu o contato com o solo. Tornou-se pernóstico. Ficou estragado pelos falsos padrões europeus. Bebe até cair. Deixa-se obcecar pelo sexo. Passa o tempo conversando e não trabalha ${ }^{95}$ ". Mais interessante do que nos perguntarmos se Gorton é verdadeiro ou falso em suas ironias é reconhecer que a função de seu personagem é proporcionar um escape, uma rota que vai para longe daquelas possíveis entre o grupo de "escritores e artistas". Da mesma forma, essa fronteira entre Espanha e França é uma rota que escapa às formas de vida metropolitanas.

Experiência dessa diferença é a maneira como os personagens do meio interiorano dominam seus próprios corpos, o que se traduz na completa ausência da catatonia de Cohn, na melancolia bipolar de Brett Ashely ou na angústia de Barnes. Esses personagens aparecem marcados por uma vitalidade impossível entre o grupo principal de escritores e artistas. Por exemplo, na descrição de uma festa entre os bascos, que o narrador assim descreverá numa simples cena:

\footnotetext{
Um deles arrebatou o saco de pele ao seu dono, que se preparava para fazer a demonstração. Era um jovem e segurou o braço estendido, erguendo-o muito alto e premindo o couro com a mão, de tal maneira que o jato de vinho esguichou-lhe a boca. Conservou-o assim, o vinho descrevendo uma trajetória rígida e ele sorvendo-o, sem se interromper, regularmente, brandamente ${ }^{96}$.
}

94 HEMINGWAY, Ernest. op. cit., 2015, p. 127.

95 Idem, Ibidem, p. 127.

96 Idem, Ibidem, p. 
São raros os momentos em que a narração prende o leitor, dessa maneira, para descrever os movimentos de um objeto. Nesse caso, uma cena bastante banal captura a atenção da narrativa por alguns instantes: o que ela revela é uma espécie de habilidade na realização de atividades muito sutis. Isso se repete na literatura de Hemingway em diversos momentos posteriores, além de se fazer presente na grande maioria dos seus contos (pensemos, por exemplo, nas descrições detalhadas da preparação de iscas para pesca ou de refeições). O tipo de atenção dedicado à exploração de detalhes no manuseio de objetos simples também se faz presente no documentário, não por acaso filmado no interior da Espanha, The Spanish Earth, e, como coloca o crítico Harry Levin, desde suas primeiras produções literárias até o documentário, o tipo de narração desenvolvida por Hemingway arranca o leitor/espectador diretamente para a ação que é descrita, como se ele também observasse aquela imagem se formando à sua frente ${ }^{97}$.

A verdade é que, desde o início da narrativa, até seu fim, o narrador jamais gozará sua vida como nesse décimo segundo capítulo. Quando encontram seu espaço idílico, Barnes e Gorton experimentam um tipo de realidade impossível, seja em Paris, seja em Pamplona. Logo, esse espaço será invadido por uma carta de Mike Campbell, o noivo de Brett Ashely, avisando que, em breve, chegariam ao festival de tauromaquia e que "Brett caiu no trem, inconsciente de tão embriagada $^{98}$ ". É como uma recaptura do mundo do qual o narrador havia se afastado temporariamente, como se a carta lhe adiantasse o retorno ao mundo que havia deixado em Paris e, portanto, o retorno a sua forma mais fragmentada.

Em Espanha, Barnes torna-se uma espécie de mediador entre os espanhóis e seus amigos, o que lhe permite esse papel é sua afición pelas touradas. Como se, porque apaixonado pelas touradas, reconhecendo nelas mais do que mero adorno ou objeto de turismo internacional, os personagens espanhóis reconhecessem em Barnes uma espécie de autenticidade rara entre os não espanhóis, pois era suposto que "um americano não poderia ter afición. Talvez a simulasse ou a confundisse com entusiasmo, mas não podia senti-la realmente ${ }^{99}$. . Mas Barnes era reconhecido entre os amantes das touradas, principalmente por Montoya, dono do Hotel onde

97LEVIN, Harry. Observations on the Style of Ernest Hemingway, The Kenyon Review, v. 13, n. 4 (Autumn, 1951), p. 581-609.

98 HEMINGWAY, Ernest. op. cit., p. 137.

99 Idem, Ibidem, p. 143. 
se hospedam, como um autêntico aficionado. O próprio Ernest Hemingway era muito ligado às touradas, não apenas enquanto objeto de ficção, mas como um evento tradicional que manteve suas estruturas e sua estética com o passar dos séculos. É possível que a escolha do nome de um dos personagens mais importantes desse bloco da narrativa, o toureiro Pedro Romero, esteja relacionada com a própria história da tourada, pois é esse o nome do toureiro representado graficamente por Francisco de Goya numa série de gravuras ${ }^{100}$ (Hemingway era um admirador tanto de Goya quanto das touradas - bastaria lembrar da série de textos de não ficção de 1932, Death In The Afternoon).

E aqui, quando os personagens ingressam em Pamplona e se estabelecem para acompanhar os eventos do festival de tauromaquia, que o romance, perceptivelmente, ingressa num outro bloco. Daqui que a "função" do décimo segundo capítulo seja uma espécie de transição entre um tipo de experiência fragmentada e superficial na metrópole e outra muito detalhada e contida nos bosques e rios da fronteira entre França e Espanha: uma vez em Pamplona, essas duas experiências se fundem. O resultado é um tipo de suspensão temporal, que resulta não apenas numa festa incessante e exaustiva, que envolve a totalidade dos personagens (pela primeira vez, o narrador vai descrever, como quem observa de um platô superior uma paisagem, todos os personagens da cidade se mobilizando em sua transformação para a recepção do festival).

\section{3 - Pamplona}

Neste bloco, há diferentes modos de perceber a narrativa através de seus personagens. Para Brett, a experiência de Pamplona é muito distinta daquela que é para Cohn ou Barnes, por exemplo. Daí que a realidade do romance continue a ser fragmentária, ainda que o narrador continue a ser um só, uma vez que ele transita entre essas diversas experiências nos outros personagens. Jacob Barnes é o primeiro e único a oferecer uma espécie de tecido geral para aquilo que estaria por

100 Como mostra Watts (1971) em Hemingway and the arts, p. 116. 
vir nas próximas páginas da narrativa; durante um dos primeiros jantares entre os personagens em Espanha, ele pensará: "Lembrei-me de certos jantares durante a guerra. Muito vinho, uma tensão ignorada e o sentimento de que iriam produzir-se coisas inevitáveis ${ }^{101} \%$. Mas o que poderia haver de tão similar entre a guerra - e aqui, é bom lembrar de que não se trata de qualquer guerra, mas da Grande Guerra, na qual Barnes fora ferido gravemente - e uma viagem entre personagens amigos? Se é possível captar uma "tensão ignorada" e compará-la com aquela que os soldados sentiam nas noites anteriores à sua ida ao front, é possível dizer que, na literatura de Hemingway, ainda nos anos 1926, a Grande Guerra estava longe de ser superada e ainda pairava uma espécie de espera por "coisas inevitáveis". Esse é um argumento presente, por exemplo, em Eksteins, para quem os anos 1920 apenas ignoraram as causas e mesmo as mais graves consequências da Primeira Guerra Mundial. A Guerra de 1914-1918, tão recente e tão destrutiva, teria sido apreendida como um objeto de ficção, sobre o qual a elaboração não foi possível $^{102}$.

Uma tensão ignorada havia sido apresentada poucos momentos antes na narrativa, quando são recebidos os touros nas arenas. Os personagens vão observar a cena, que inclui o trabalho ingrato por parte de alguns bois e servir de objeto de descarga de tensão para os bois recém-chegados. Eles recebem os primeiros ataques dos touros, sem revidar, servindo apenas para acalmá-los. A comparação entre os bois e Robert Cohn pareceu inevitável para Mike Campbell: "Julguei que você gostaria muito de ser boi, Robert". E continua: "Por que segue Brett por toda parte, como um pobre boizinho? Não sabe que não é desejado? Foi a San Sebastián, onde ninguém o queria, e andou atrás de Brett, por toda parte, como um maldito boi" ${ }^{\prime 103}$.

Essa espécie de animalização - e, mais especificamente, a aproximação entre um personagem masculino e um bovino, num contexto onde o bovino deve ser caçado e abatido - vai ser explorada em outros momentos na literatura de Hemingway ${ }^{104}$. Contudo, é bom lembrar que, desde as primeiras páginas do

101 HEMINGWAY, Ernest. op. cit., p. 158.

102 EKSTEINS, Modris, op. cit., 1992. Ver o quarto capítulo do livro.

103 HEMINGWAY, Ernest. op. cit., p. 153.

104 Ver, por exemplo, a análise de The Short Happy Life of Francis Macomber no próximo capítulo. 
romance, as humilhações e perversidades atravessadas por Robert Cohn não passam indiferentes ao narrador. Barnes reconhece em Cohn o mesmo desejo por Brett, assim como o desejo de sair de si mesmo. Não é por acaso que, poucos momentos depois de constatar o clima de tensão mencionado acima e experienciar mais essa humilhação, Barnes sinta-se ele mesmo humilhado por Brett. Deitado em sua cama, ele ingressa numa reflexão sobre o valor, que termina - como naquelas reflexões comuns à geração de vanguarda -, segundo Hannah Arendt, esvaziando o conceito de qualquer sentido:

\begin{abstract}
Uma simples troca de valores. Renuncia-se a uma coisa e recebe-se qualquer coisa em troca. Ou então trabalha-se por alguma coisa. $\mathrm{Ou}$ pagamos sempre, de um modo ou de outro, por todas as boas coisas. Eu pagava por muito do que gostava e assim tive bons momentos. Paga-se, seja ouvindo falar dessas coisas, ou por experiência, ou correndo riscos, ou com dinheiro. Gozar a vida consiste em obter com dinheiro o mais possível. O mundo é bom lugar para essa espécie de transações. Parecia-me uma boa filosofia. "Dentro de cinco anos", pensei, "eu a julgarei tão falsa como todas as outras boas filosofias que já adotei". ${ }^{105}$
\end{abstract}

Ou seja, está reconstituído o retorno àquele Barnes das primeiras reflexões sobre a impossibilidade de "escapar de si mesmo"; por onde quer que olhe, ele vê a mesma coisa - daqui que ver todos os países seja equivalente à ida ao cinema, que qualquer sul-americano the parece idêntico e que todas as "boas filosofias" possam ser abandonadas num período de cinco anos. Ele termina: "Tudo que eu desejava era saber como viver. Talvez aprendendo como viver acabemos compreendendo o que há realmente no fundo disso tudo ${ }^{106 "}$ "

Mas a experiência desse bloco da narrativa não está reduzida a essas reflexões, pois há também toda uma dimensão festiva na qual realidade e ficção parecem encontrar um espaço comum. O dia seguinte é marcado pela "explosão da fiesta", que explode não apenas num sentido alegórico, dando início à emergência de danças, a diferentes personagens, hábitos, comportamentos, travessias pela cidade, mas também da suspensão temporária da experiência objetiva da realidade. A narração, a partir daí, mistura tanto descrições diretas de Barnes como visões panorâmicas de Pamplona, que se transforma durante o festival:

105 HEMINGWAY, Ernest. op. cit., p. 160. 106 Idem, Ibidem. 
Tudo se tornou absolutamente irreal, e semelhava que nada mais poderia ter consequência. Parecia deslocado, ali, pensar em consequências, e durante a fiesta, mesmo nos momentos de calma, tinha-se a impressão de que era preciso gritar para fazer-se ouvir, quando se tinha de dizer alguma coisa. Era a mesma sensação em tudo que fazíamos ${ }^{107}$.

Durante esse período "absolutamente irreal", o narrador descreve a experiência da fiesta a partir de Brett Ashley que, ao contrário dele mesmo ou de Cohn, atravessa as festividades enquanto objeto de desejo. A seguinte descrição deu margem a uma série de interpretações que, apesar de interessantes, imputam talvez demasiado sentido num romance mais bem descrito como superficial do que profundo. Trata-se da descrição do movimento feito pelos personagens espanhóis para utilizar Brett enquanto ídolo:

\footnotetext{
Alguns [dançarinos] formavam círculo em torno de Brett e puseram-se a dançar. Esses dançarinos traziam ao pescoço grande guirlandas de algo. Seguraram-nos pelos braços, a mim e a Bill, e nos fizeram entrar na roda. (...) Queriam-na como uma imagem, em torno da qual dançavam ${ }^{108}$.
}

Se, para Brett, a experiência da fiesta é de gozo, isso inclui não só sua metamorfose em imagem, mas também aquilo que Robert Cohn vai considerar uma espécie de gozo sádico, ao assistir aos ataques dos touros nas arenas. Brett, como os outros personagens, assistem às batalhas na arena de touradas sob a expectativa de que os touros sejam violentos. Tal violência, em lugar de provocar um afastamento, torna tudo ao seu redor mais atraente - e aí uma nova aproximação importante aparece na figura de Pedro Romero.

No próximo capítulo, teremos a oportunidade de discutir, com mais minúcias, como a figura de Romero se insere numa série de figuras mobilizadas por Hemingway para fins específicos. Já nesse primeiro romance importante, está constituída a função que um personagem como Romero vai ganhar na literatura heminguiana: em contraposição às figuras fragmentadas e frágeis representadas nos "escritores e artistas", personagens como Romero ou Santigo (de $O$ Velho e $O$ Mar) levam a experiência da morte até suas últimas consequências. A 
proximidade com o perigo, mas, principalmente, a proximidade corporal com a morte é a característica constituinte deles.

Em Romero, trata-se menos de um estereótipo do "grande matador", marcado por localismos ou regionalismos culturais, do que de uma figura singular. Ainda muito novo, é conhecido como o melhor toureiro da Espanha, já que “outros não podem aprender o que ele já sabia de nascença ${ }^{109 "}$. A autenticidade na sua conduta, dentro e fora das arenas, não deixa de ter seu efeito no grupo de personagens que vem de Paris com Barnes. Todos reconhecem suas próprias condições como inferiores a Romero; Gorton dirá: "Diga-lhe que acho sórdida a profissão de escrever (...) Diga-lhe que me envergonho de ser escritor ${ }^{110}$ ". Pois, enquanto todos eles se preocupam se vivem realmente suas vidas, Romero parece vivê-la justamente ao deixar-se levar em direção ao perigo da morte. Essa autenticidade tem papel fundamental em Brett, dessa vez, será ela que será fixada pela figura de Romero.

A fixação e o desejo que marcam a experiência de Brett neste bloco na narrativa contrapõem-se perfeitamente à experiência de Barnes: é ele que é mobilizado como um instrumento de mediação entre Romero e Brett. Mais uma vez, seu papel de mediação entre os espanhóis e os expatriados funciona aqui quase contra sua vontade; já para Montoya (o dono do hotel onde estão hospedados), seus companheiros apareciam como uma espécie de vergonha, mas aqui Barnes deve agir deliberadamente contra si mesmo para realizar um desejo de Brett - desejo sobre o qual nem ela tem qualquer controle (dizendo: "Deus sabe que nunca me senti tão prostituta"111).

A tensão, contudo, não se perde com a realização dos desejos de Brett; ainda entre os expatriados existia aquela atmosfera de tensão ignorada que Barnes comentara. É evidente a função que Cohn terá na continuidade e no ápice dessas tensões, já que sofre duplamente do mesmo mal que todos os expatriados, mas ainda é estigmatizado pelo antissemitismo marcante dos personagens (por exemplo, quando Campbell diz: "Livre-nos desse seu lastimável rosto judeu"12"”). Mas, uma vez que Brett mobiliza seu desejo em direção a Pedro Romero, o

109 Idem, Ibidem, p. 182.

110 Idem, Ibidem, p. 191.

111 Idem, Ibidem, p. 200.

112 Idem, Ibidem, p. 193. 
comportamento lívido de Cohn é alterado. Como se houvesse limites à própria desterritorialização que ela operasse no romance, Cohn tenta estabelecê-los entre o grupo de expatriados. Quando em contato com Romero, Brett ativa em Cohn uma energia que nenhuma das humilhações anteriores foi capaz: ele agride não só Romero, mas também o narrador, Jacob Barnes.

No entanto, a explosão em Cohn não vem também sem um sentido no próprio romance, já que ela é acompanhada de uma segunda explosão de violência durante o festival em Pamplona. Finalmente, pela primeira e última vez durante toda a narrativa, ações violentas são descritas, tendo Cohn e os touros como seus protagonistas:

\footnotetext{
Quando os touros passaram galopando juntos, pesados, os flancos enlameados, balançando os chifres, um deles saltou para frente e atingiu, nas costas, um dos homens que corriam, e elevou-o no ar. $\mathrm{O}$ homem, com os braços estendidos dos lados do corpo, sacudiu a cabeça ao ser chifrado (...)

O homem ferido jazia de bruços na lama pisada. Saltava gente por cima da barreira e eu não podia vê-lo, porque a multidão que o rodeava era densa demais. Erguiam-se gritos, no interior. Cada grito significava que um touro assaltava a multidão. Pela intensidade do clamor, podia-se avaliar a gravidade do que se passava lá dentro ${ }^{113}$.
}

Contudo, lê-se, poucas linhas depois, o narrador dizendo: “Afastei-me da barreira e retomei o caminho da cidade. Lá chegando, fui tomar café com torradas". Daí que seja possível falar numa mesma incapacidade de elaborar os eventos violentos que marcam a vida do narrador - seja, no passado, com o acidente de guerra, seja, no presente, com os ataques dos touros. Somente um personagem, que surge tão brevemente quanto é sua fala, comenta o ocorrido; trata-se do garçom que serve Barnes, e o avisa que o homem chifrado pelo touro morrera: "Ouviu? Muerto. Está morto. Morreu. Traspassado por uma chifrada, apenas porque foi se divertir essa manhã. Es muy flamenco ${ }^{114 "}$. A banalidade com que essa morte é tratada imediatamente pelo narrador é seguida por uma série de outros indicativos de que não é apenas Jacob Barnes que tem sua sensibilidade intocada pelo evento. Num momento posterior, é Pedro Romero que mata esse mesmo touro, responsável pela morte do homem citado. Ao abatê-lo, ele corta sua 
orelha e a entrega de presente para Brett Ashley, que "a envolveu em um de seus lenços e deixou o lenço e a orelha, bem como algumas pontas de cigarro Muratti no fundo da gaveta na mesa de cabeceira ${ }^{115 "}$ do seu hotel.

Há, portanto, uma superficialidade muito distinta na maneira como Hemingway desenvolve esse romance; não apenas eventos de potencial trágico são retratados de forma banal na constituição de seus personagens, como também alguns dos mais importantes momentos da narrativa são imediatamente superpostos por descrições que retiram da situação toda a sua profundidade. Isso está latente desde a aparição da prostituta Georgette, lacônica, ao comentar o fato de Barnes ser sexualmente impotente devido a um ferimento de guerra: "Essa maldita guerra", até a forma como é descrito o destino da orelha do touro no trecho anteriormente destacado. Por não elaborar literariamente determinados eventos e situações em busca de sentidos que estejam para além do que é narrado, o romance prefere uma descrição sempre superficial dos objetos e ações; é, ao fazê-lo, que Hemingway captura e dá forma a um tipo de literatura, aqui chamada de superficial. É como aquilo que Jean Paul Sartre elogiara na releitura feita pelos autores franceses de escritores americanos, aproximando Ernest Hemingway de Albert Camus ${ }^{116}$ : a atenção dada a um objeto ou a uma ação não tem mero efeito de estilo, mas resulta numa narrativa terrena. Talvez o que Sartre reconheça nessa proximidade seja a presença do corpo dentro do texto, ou seja, do uso das palavras - que consiste numa redução da linguagem, naquele sentido deleuziano - na busca da constituição de formas literárias corporais: o significado imaterial dos eventos e objetos é banal, a conduta vigorosa do corpo aparece como virtuosa.

Bastaria reconhecer que, ao elaborar o personagem Pedro Romero, por exemplo, não foi necessária uma descrição além daquelas em que já o encontramos posto em ação. E há, nessas passagens, todo um detalhamento muito mais atencioso e preciso do que quaisquer dos monólogos da narrativa. Por exemplo, no momento em que Pedro Romero derruba o último touro do festival de San Fermín, trata-se tanto da descrição de um fato quanto da própria constituição do personagem:

115 Idem, Ibidem, p. 216.

116 SARTRE, Jean-Paul. Situações I. São Paulo: Cosac \& Naify, 2005, p. 117-132. 
Durante um momento, o homem e o touro formaram um todo. Romero estava inclinado sobre o touro, com o braço estendido muito ao longe, tocando o ponto onde se fixava o punho vermelho da espada. Então a figura dissolveu-se. Com um pequeno salto, Romero desprendeu-se e, em seguida, em pé, com a mão erguida, enfrentou o touro, a camisa rasgada sob a manga, o tecido adejando ao centro. E o touro, com o punho vermelho da espada fixado entre os ombros, baixava a cabeça, firmando-se nas patas ${ }^{117}$.

\section{4 - Madrid}

O fim das touradas marca o fim do festival de San Fermín, assim como sinaliza a transição para o último bloco da narrativa. É relevante que o final do romance seja marcado pela ausência de grande reflexões por parte dos personagens sobre o que aconteceu; como dirá Gorton, no início desse que nos parece o terceiro e último bloco da narrativa: "tenho a impressão de que tudo não passou de um pesado maravilhoso ${ }^{118}$ ".

A trajetória de Jacob Barnes ainda recebe alguns últimos dias no litoral da Espanha, enquanto Brett Ashely segue fugida com Pedro Romero. Como naquele curto período que marca o décimo segundo capítulo do romance, a descrição dos dias de Barnes é marcada por uma espécie de idílio passageiro: seu fim é determinado, justamente, por Brett Ashley que, mais uma vez, solicita a sua companhia ao ver-se abandonada por Romero. Barnes deixa San Sebastián e vai para Madrid, encontrá-la, de modo que a narrativa retorna às figuras da grande cidade: o romance termina com os dois personagens no banco traseiro de um táxi, circulando pelas ruas noturnas de Madrid. Antes de deixar o interior para a capital espanhola, Barnes se pergunta qual seria, afinal, o sentido de sua persistente conduta sob o domínio da figura de Brett Ashley:

\footnotetext{
Assim parecia resolvida a situação. Isso mesmo. Despachar uma moça com um homem. Apresentá-la a outro, para que ela fugisse com ele. Depois era preciso ir procurá-la e terminar um telegrama por "afetuosamente". Ótimo ${ }^{119}$.
}

117 HEMINGWAY. Ernest. op. cit., p. 237.

118 Idem, Ibidem, p. 241.

119 Idem, Ibidem, p. 258. 
Não por acaso, também, novamente em Madrid, Brett Ashley parece tão próxima, ainda que absolutamente distante do narrador. Ela solicita sua presença no hotel em Madrid, só para que possa chorar em seu colo e desejar outro personagem: "Vou procurar Mike novamente - senti que ela chorava em meus braços -. Ele é tão amável e tão horrível! É disso que eu preciso ${ }^{120 "}$.

O motivo pelo qual Romero a deixa é bastante explícito: Brett, enquanto força desterritorializadora, precisa se reterritorializar - assim, ela explica a Jacob Barnes: "Ele queria que eu deixasse crescer os cabelos", e assim "queria ter certeza de que eu não o deixaria nunca. Além disso, eu me tornaria mais feminina, naturalmente ${ }^{121}$ ”. Contudo, seria contrária à função estabelecida por Hemingway para a personagem o papel que Romero desejaria; é natural que Brett termine nos braços de Barnes, já na promessa de uma nova ramificação em sua vida. O que existiu entre os dois personagens ressoa, nas últimas linhas do romance, como apenas uma promessa irrealizada, quando Brett diz: "Poderíamos ter sido tão felizes juntos!", ao que Barnes lhe responde: "É sempre agradável pensar nisso $^{122 \%}$

\section{5 - Conclusão}

Os meios empregados por Hemingway, nesse romance, não apenas diferem daquela tradição literária dos grandes romancistas ingleses, franceses e russos, lidos por Hemingway através da orientação de Gertrude Stein (o que é reconhecido pelo próprio autor e por todos os seus biógrafos), mas também em debate com contemporâneos, como Ezra Pound e Scott Fitzgerald. As intenções literárias de Hemingway sempre apareceram como mais simples, os contos e romances que produziu durante os anos 1920 desenvolviam sua narrativa a partir de formas literárias muito menos sofisticadas do que as de qualquer outro escritor modernista associado à chamada "geração perdida". Ainda assim, muitos elementos em $O$ Sol Também Se Levanta cativaram a atenção não apenas de seus pares escritores como também a de críticos na Europa e nos Estados Unidos.

120 Idem, Ibidem, p. 262.

121 Idem, Ibidem, p. 260-1.

122 Idem, Ibidem, p. 266. 
Desde os contos de In our time (1924) até a publicação de Adeus às armas (1929), Hemingway jamais deixou de utilizar, como material para a produção de sua literatura, objetos e ações muito simples, contudo, muito pormenorizadamente descritos. Parece nunca ter sido atravessado por um grande projeto, como o Ulysses, de Joyce; na verdade, a História parece um elemento de investigação literária bastante ausente nas suas narrativas. Voltando-se para o imediato, para o tempo presente diante de sua própria vida, Hemingway produziu, porém, um objeto historicamente interessante, na medida em que, atualmente, o historiador tem a oportunidade de investigar o número de fragmentações que uma simples narrativa a respeito de um grupo de expatriados precisa considerar. O Sol Também Se Levanta é um texto que apareceria de forma completamente diferente sob a perspectiva de outros personagens, mesmo se tratando daqueles muito próximos do narrador.

A experiência do festival e a da metrópole são os maiores exemplos de que, tanto a pequena vila como a cidade só poderiam ser captadas numa fração muito individual, a depender da perspectiva. Esse processo, é claro, não se inicia com Hemingway (como tentamos demonstrar no exemplo de Baudelaire, com o pequeno poema em prosa Os olhos dos pobres $^{123}$ ), no entanto, num romance despretensioso como o que se viu aqui, emergem todas aquelas questões cruciais para a formação de literatura modernista.

Este capítulo buscou conduzir uma pesquisa a respeito de um romance, considerando-se aquelas contribuições de Gilles Deleuze para o estudo da literatura norte-americana no século XX, já destacadas anteriormente. Acreditamos que foram explicitados pontos suficientes para iniciar uma discussão, não só sobre Hemingway mas também sobre a oposição entre literatura "superficial” x "profunda" - como ressaltamos nos ensaios de Erich Auerbach ${ }^{124}$.

A investigação, contudo, está longe de uma conclusão, uma vez que seria necessária uma comparação com o arquétipo literário oposto. Arriscando aqui uma suposição, parece-nos que é possível ver um dos representantes dessa literatura profunda em Thomas Mann. Assim, não seriam opostos quase diametrais os níveis

123 Primeiro capítulo desta dissertação.

124 AUERBACH, Erich. Mímesis: a representação da realidade na literatura ocidental. São Paulo: Perspectiva, 1971 (ver o primeiro capítulo do livro citado e a discussão presente no segundo capítulo desta dissertação). 
de profundidade que desejam atingir as reflexões presentes em $A$ Montanha Mágica (1924) e O Sol Também Se Levanta (1926)? Tal suposição não propõe um exercício gratuito de literatura comparada, mas sim de reconhecer que essas duas formas de romances continuaram a habitar a literatura europeia durante o período entreguerras. A tarefa fica, no entanto, para outro momento e outros pesquisadores. 


\section{Tornar-se um com o touro: a natureza segundo Ernest Hemingway}

\section{1 - Introdução}

É possível falar numa função específica para a "natureza" na obra de Ernest Hemingway. Seus biógrafos relatam a importância que estar em meio à natureza teve durante toda a sua vida, além disso, as cartas são também significativas nesse sentido. A forma de experiência da vida mais importante para Hemingway, mais do que ler e escrever, talvez tenha sido o encontro com o mundo não humano através do corpo. Isso, contudo, não parece justificar uma leitura "naturalista" ou "primitivista" do autor (é preciso discordar do uso da expressão bom selvagem, como o faz Beiguelman ${ }^{125}$ ). Pareceria mais interessante investigar como a sua literatura depende da funcionalização de figuras e ambientes naturais e de personagens atravessados pelo mundo natural. Tanto personagens não humanos como os espaços naturais obtêm um papel específico dentro da narrativa. "Função" pode seguir o modelo desenvolvido por Mikhail Bakhtin, em seu estudo sobre Dostoiévski ${ }^{126}$, em que certos elementos indicam o agenciamento de determinadas sensações e efeitos durante uma narrativa.

Parece que a função da natureza na literatura de Hemingway é a de desvelar, sob novas formas, os personagens humanos. Tal função emerge na narrativa para capturar suas imaginações e os empurra num combate, do qual saem metamorfoseados. A atribuição dessa potência transformadora ao mundo natural só é possível quando o natural se opõe ao humano, marcado pela transitoriedade, banalidade e perversidade. Nenhum outro evento na obra de Hemingway é marcado, de forma mais clara, por essas três características do que a guerra - e, ao menos, até Por Quem os Sinos Dobram - o amor conjugal. O mundo exclusivamente humano do lar (como aquele que se anuncia em The End

125 BEIGUELMAN, Gisele, op. cit., 1993.

126 BAKHTIN, Mikhail. Problems of Dostoevsky Poetics. Trad. Caryl Emerson. MinneapolisLondon: University of Minnesota Press, 1984. 
of Something) e o da guerra são similares em muitos sentidos: são representados como um ciclo vicioso de perversidade banal.

O lar em que Hemingway crescera parece ter sido dominado pela tirania de sua mãe, que chegou a expulsá-lo de casa quando ele retorna da Primeira Guerra. Ainda adolescente, numa carta, Hemingway retrata seu pai como um sujeito extremamente covarde. Não são poucos os contos dos anos 1920 que apresentam os personagens masculinos como fracos e fragmentários, submetidos ao sofrimento diante de uma figura feminina. Isso, contudo, não significa que Hemingway tenha simplesmente projetado o mundo familiar de sua infância em sua literatura. Existe uma função específica do mundo natural para esse tipo de personagem masculino fragmentado: reconstituir sua existência no mundo. Podese imaginar que, diante desse embate (masculinidade fragmentada e feminilidade tirânica), a Natureza apareça como uma espécie de via de fuga da realidade. No entanto, o mundo natural, em Hemingway, não retira os personagens da realidade presente na narrativa, mas permite que eles criem novos laços com ela.

\section{2 - Ser um com o touro: o corpo-sem-órgãos de Hemingway}

Uma imagem literária pode ser mais elucidativa neste primeiro momento de nossa investigação. Em certa altura de $O$ Sol Também Se Levanta, o grupo de personagens principais assiste a uma tourada no interior da Espanha, na cidade de Pamplona. A atmosfera desse bloco da narrativa havia sido descrita poucas páginas antes pelo narrador como uma "tensão ignorada e o sentimento de que iriam produzir-se coisas inevitáveis". Os conflitos entre os personagens giravam também em torno de uma estrutura que guardava uma figura feminina tirânica (ou sádica, Brett Ashley) e diversos personagens masculinos internamente fragmentados, que disputavam entre si a atenção da primeira.

Eis que surge um novo tipo de figura masculina, o toureiro Pedro Romero. Muito diferente de todos os outros personagens, Romero não é fragmentado e não será dominado por Brett Ashley da mesma forma que os outros personagens. 
Depois de uma série de eventos, descritos mais minuciosamente em outro lugar ${ }^{127}$, o narrador descreve o momento exato em que Pedro Romero mata seu primeiro touro, durante o festival de San Fermín:

\begin{abstract}
Romero, de perfil, em frente ao touro, tirou a espada da muleta. Ergueu--se nas pontas dos pés e apontou a lâmina. O touro arremeteu no mesmo instante em que Romero, e a mão esquerda do toureiro deixou cair a muleta sobre o focinho do animal, para cegá-lo, e seu ombro direito avançou entre os chifres, enquanto a espada penetrava na corcova. Durante um momento, o homem e o touro formaram um todo ${ }^{128}$.
\end{abstract}

Perceber a continuidade entre homem e touro, reconhecer a junção entre os dois corpos, significa, para o narrador, uma nova experiência da realidade. Como tentamos mostrar nos dois últimos capítulos desta dissertação, a literatura de Hemingway é constituída por fragmentações. Somente Pedro Romero experimenta a inteireza ao penetrar o corpo do touro com sua espada. Forma-se, nessa ligação homem-espada-touro, o que podemos chamar de corpo-sem- órgãos da literatura de Hemingway. Esse corpo-sem-órgãos heminguiano não, por acaso, aparece entre homem e animal; na transição de Paris a Pamplona, passando pela região montanhosa que separa Espanha e França, os personagens Jacob Barnes e Bill Gorton já reconhecem um tipo de realidade bastante diferente daquela da cidade. Ali, a pele de um camponês basco, curtida pelo sol, confunde-se com o couro do banco do ônibus. As cores de elementos não humanos, como o sol, as montanhas, o pó, começam a se misturar com os personagens humanos, marcando suas peles, prendendo-se às suas roupas.

Também em Por Quem os Sinos Dobram, Hemingway elaborou essa relação entre personagens humanos, não humanos e sua paisagem no interior da Espanha: para o autor, o tipo de ambiente natural habitado por seus personagens mistura-se com eles. A beleza da personagem Maria, por exemplo, só pode ser plenamente captada através de uma imagem humana atravessada pelas imagens

127 Ver o terceiro capítulo desta dissertação.

128 Tradução de: "He profiled directly in front of the bull, drew the sword out of the folds of the muleta and sighted along the blade. The bull watched him. Romero spoke to the bull and tapped one of his feet. The bull charged and Romero waited for the charge, the muleta held low, sighting along the blade, his feet firm. Then without taking a step forward, he became one with the bul" (grifo meu). 
vegetal e animal: "Seu cabelo era daquele castanho dourado de um campo de trigo queimado pelo sol, cortado rente ao crânio como uma pele de castor ${ }^{129}$ ". Não é por acaso que Robert Jordan chame-a de "coelhinha" ("little rabbit").

Daí que a função assumida de personagens como Pedro Romero se exerça apenas na mediação entre a civilidade e os instintos, entre homens e touros. Para a literatura de Hemingway, somente os personagens capazes de ingressar num combate na natureza (seja uma tourada, uma pescaria ou uma caçada) são capazes atravessar uma transformação verdadeira. Para o autor, uma vez constituído o corpo-sem-órgãos, pouco importa ser necessário que um dos pares dessa relação deva perecer. Os personagens que matam animais são os mais capazes de amá-los. Anselmo dirá, em Por Quem os Sinos Dobram, que o urso é como um irmão do homem, ainda que ele seja um caçador. Santiago, em $O$ Velho e $O$ Mar, se pergunta se não seria um pecado ainda maior matar o peixe, uma vez que ele também o ama como se fosse um irmão.

Existem procedimentos, técnicas e modos de conduzir a formação desse corpo-sem-órgãos; não é todo pescador que poderá transformar-se depois de uma pesca, como Nick Adams ou Santiago, assim como não há toureiro que consiga "tornar-se um com o touro", como Pedro Romero em O Sol Também Se Levanta $^{130}$.

A função da natureza na obra de Hemingway não é passiva, como se simplesmente "estivesse lá" como paisagem. Ao abrir um campo de possibilidades para a transformação dos personagens, a natureza é ativa. Essas ações não são predatórias, não têm interesse lucrativo e não se pode falar de competição. Em Big Two-Hearted River, por exemplo, o narrador informa que Nick Adams se interessa pela quantidade ou pelo tamanho de suas pescas. Não se trata de acumular resultados materiais, nem premiações, mas, por meio de um combate na natureza, escapar do mundo puramente humano que cerca esses personagens. $\mathrm{O}$ mesmo vale para as lutas de boxe, que determinam regras, treinos e exigem entrega por parte de seus participantes. Muito diferente é como aparecem os assassinatos em The

129 Tradução de: "Her hair was the golden brown of a grain field that has been burned dark in the sun but it was cut short all over her head so that it was but little longer than the fur on a beaver pelt".

130 Sobre o conceito de corpo-sem-órgãos ver DELEUZE, Gilles \& GUATTARI, Félix. Mil Platôs - Capitalismo e Esquizofrenia, v. 3. São Paulo: Editora 34, 2010 e O Anti-Édipo. São Paulo: Editora 34, 2011. 
Killers (1927) e a guerra e as brigas de rua em Islands in the Stream (1970). Dominados pelo elemento puramente humano, que, na linguagem heminguiana, significa banalidade e perversidade.

Os personagens mais importantes da obra de Hemingway têm procedimentos muito bem planejados. As suas ações na natureza, mesmo as mais simples, são sempre detalhadamente descritas. Desde a forma como Santiago conduz as cordas e linhas em $O$ Velho e $O$ Mar até a maneira como Nick Adams captura gafanhotos para a pesca, há procedimentos para a condução dos combates que eles operam na natureza: todos eles levam a uma espécie de corpo-semórgãos. 


\section{Por Quem os Sinos Dobram e $O$ Velho e $O$ Mar: máquinas paranoicas e devir-revolucionário}

\section{1 - Introdução}

Por Quem os Sinos Dobram e $O$ Velho e $O$ Mar são os textos mais importantes do período final da vida de Hemingway. O tempo que os separa é fundamental (1940-1952), não apenas em razão de algumas continuidades no desenvolvimento da narrativa heminguiana, mas também porque revela uma mudança significativa na relação entre literatura e política. Se o contexto da produção de Por Quem os Sinos Dobram é marcado pela intervenção pública (e, no caso de Hemingway, diretamente militar) de um conjunto considerável de escritores, artistas e intelectuais na Guerra Civil Espanhola, o pós-Segunda Guerra exigiu maior astúcia por parte dos escritores que não desejassem associação a um dos lados do conflito geopolítico entre socialismo soviético e americanismo liberal.

Ernest Hemingway apoiou diretamente a intervenção soviética na Guerra Civil Espanhola, chegando inclusive a elogiar a proatividade de Stálin, que contrastava com a decisão pela neutralidade estadunidense. O escritor, como Robert Jordan, protagonista de Por Quem os Sinos Dobram, sabia que seria chamado de "vermelho", mas essa era uma consequência menor diante do que se passava em Espanha. Durante a Revolução Cubana, Hemingway, que era quase um cidadão cubano, declarou apoio e admiração pelos guerrilheiros, inclusive por Fidel Castro. Mas jamais produziria uma obra como Por Quem os Sinos Dobram em sua homenagem, como fez com os guerrilheiros da Guerra Civil Espanhola. Suas últimas duas obras têm Cuba como seu ambiente: $O$ Velho e $O$ Mar e Ilhas na Corrente (1970). Evidentemente, porém, a política não foi abordada em nenhuma delas da mesma maneira como foi no romance de $1940^{131}$. Contudo, isso não significa que esteja vetada uma leitura política de $O$ Velho e $O$ Mar; pelo

131 Tal fato seria impossível, uma vez que $O$ Velho e $O$ Mar é anterior à revolução cubana, e Ilhas na Corrente é um livro póstumo e inacabado. 
contrário, é nessa obra que, talvez pela primeira vez, apareça a tentativa de dar forma àquilo que Deleuze e Guattari chamaram de devir-revolucionário ${ }^{132}$.

Giselle Beiguelman ${ }^{133}$ percebeu como, no embate entre os personagens republicanos e fascistas de Espanha, Hemingway transpôs motivos que ultrapassavam, em muito, as condições nacionais e regionais que envolveram o conflito, de modo que um leitor de Por Quem os Sinos Dobram apreendesse a luta pela liberdade daqueles personagens como uma luta universal pela liberdade de toda a humanidade. Do mesmo modo, o roteiro preparado por Hemingway para o documentário Spanish Earth (1937) tende a mostrar como a luta dos espanhóis republicanos pobres estava além de posições nacionais, ideológicas e de interesse estratégico: o documentário tem um potencial realmente tocante, uma vez que Hemingway consegue deslocar a atenção do espectador para o corpo dos personagens, para a forma como manuseiam seus objetos de trabalho e de guerra, como conduzem animais ou como montam um sistema de distribuição de água. Para Spanish Earth, a vitória republicana significaria mais do que a afirmação de uma ideologia sobre outra, mas também do direito de um povo sobre sua própria terra e seus próprios corpos. Contra a máquina fascista - o fascismo aparece sempre enquanto máquina, como percebera Allen Guttman em sua leitura do romance ${ }^{134}$. Hemingway apresenta os corpos republicanos. Essa diferença será igualmente fundamental na estruturação de Por Quem os Sinos Dobram.

Pode-se dizer que esses são os dois momentos mais políticos da obra literária de Hemingway. Contudo, enquanto Por Quem os Sinos Dobram e Spanish Earth tomam uma posição muito direta diante do confronto que se desenrola no cenário político internacional, $O$ Velho e $O$ Mar desenvolve um devir-revolucionário através da loucura de Santiago.

\section{2 - Linhas e máquinas na literatura de Hemingway}

132 Sobre o conceito de "devir-revolucionário", o quarto volume de DELEUZE, Gilles \& GUATTARI, Félix. Mil platôs: capitalismo e esquizofrenia - 5 v. São Paulo: Editora 34, 1995.

133 DELEUZE, Gilles \& GUATTARI, Félix. Mil platôs: capitalismo e esquizofrenia - 5 v. São Paulo: Editora 34, 1995.

134 GUTTMAN, Allen. Mechanized Doom: Ernest Hemingway and the Spanish Civil War. The Massachusetts Review, v. 1, n. 3 (Spring, 1960), p. 541-561. 
$O$ Velho e $O$ Mar (1952) é uma novela que revisita não apenas conteúdos da literatura norte-americana, mas também um de seus principais motivos, identificado, ao menos, desde o livro clássico de D. H. Lawrence ${ }^{135}$ : a produção de uma linha de escape pela trajetória do protagonista para fora do solo comum de sua comunidade.

Deleuze e Guattari utilizaram seu conceito de desterritorialização ${ }^{136}$ para definir esse motor da literatura de Kafka e aqui vamos fazer empréstimo ao termo para analisar o texto de Hemingway.

Santiago, o protagonista da novela, vai ser uma figura importante para a leitura posterior da obra de Hemingway ${ }^{137}$, nos Estados Unidos, mas ele também vai habitar corações e mentes dos escritores cubanos no período prérevolucionário da ilha, como atestam as memórias de Guillermo Cabrera Infante $^{138}$. Aquele é um personagem cujas contradições se aproximam do limite. Sua morada é como uma toca entre a terra e o mar, sua companhia é um rapaz adolescente - que contrasta com sua velhice -, ele é magro até os ossos, mas forte como o próprio mar (o narrador revisita as memórias desse pescador que, já velho, vencera uma queda de braço que durou três dias e três noites), sua pele é curtida pelo sol até que se pareça com o próprio barco em que rema. Como os personagens de Conrad e Melville, estão mais em casa no mar do que na terra, isso não permite que ele forme uma comunidade fixa em $O$ Velho e $O$ Mar. Ele não é um herói marginalizado, marcado pela clandestinidade - como aqueles que Hemingway produz em Ter ou Não Ter (1937) -, na qual encontra uma comunidade paralela de excluídos. Ele é um sujeito atomizado, excluído entre os marginais, portanto, adequado àquelas condições propícias ao aparecimento do que Deleuze e Guattari chamaram de língua menor ${ }^{139}$. Seus últimos vínculos com o mundo humano são a companhia do garoto, um adolescente que costumava acompanhá-lo nas pescarias, e sua fixação pelas ligas norte-americanas de

135 LAWRENCE, D. H. Studies in Classic American Literature. Cambridge/Nova York: Cambridge University Press, 2003.

136 Conceito presente em diversas obras dos autores, com destaque para O Anti-Édipo, Kafka: por uma literatura menor e Mil Platôs.

137 BAKER, Carlos. Hemingway: o escritor como artista. Rio de Janeiro: Civilização Brasileira, 1974.

138 INFANTE, Guillermo Cabrera. Corpos Divinos. São Paulo: Companhia das Letras, 2016.

139 Aqui, nos referimos diretamente ao texto de Kafka: por uma literatura menor. Belo Horizonte: Autêntica, 2017. 
baseball, que segue pelo rádio e por jornais velhos. Dirá ele mesmo sobre si que é "um velho estranho" e que - sem nunca se referir da mesma maneira em relação aos homens - é de todas as criaturas do mar.

Quando a novela começa, Santiago está marcado por uma maré de azar, entendida pela comunidade como uma espécie de maldição, o que reforça sua exclusão: ele não pescava nada há mais de oitenta dias. Santiago ingressa na novela abaixo das condições de subsistência (não há mais comida em sua casa, e ele depende das boas ações do adolescente para viver). Além disso, é viúvo e, da antiga esposa, guarda apenas uma fotografia em sua casa/toca.

Ainda assim, ele retorna ao mar no segundo dia da narrativa, assim como fizera todos os dias antes desse. A novela cobre a extensão de dois dias e meio, mas, à medida que avança no mar (a pescaria começa no início do segundo dia), as barreiras entre sonho e realidade, entre sono e vigília vão se borrando - uma das razões de tal pescaria, desumanamente longa, pode ser captada na forma de uma novela.

Santiago pesca num barco muito rústico, tem de fazer tudo com as mãos e, sozinho, ele correrá sempre o risco de morte se for até os limites de suas forças. Mesmo assim, ele vai além das áreas de pesca compartilhadas. Quer alcançar águas profundas e, a partir daqui, já se torna mais claro aquele processo de desterritorialização. Ao ingressar nesse novo espaço de águas profundas, a linha de Santiago é mordida; então, dá-se uma das séries de eventos mais marcantes da literatura de Ernest Hemingway: o encontro com o Marlin gigante, que Santiago chamará, até o fim do texto, de "o peixe". Trata-se de um peixe de proporções irreais, de beleza incomparável, mas que, ainda submerso, não poderia sequer ser imaginado no seu conjunto.

Assim como Pedro Romero opera uma relação entre toureiro-espada-touro em $O$ Sol Também Se Levanta, a novela também apresenta a construção de um corpo-sem-órgãos na inter-relação entre velho-linha-peixe. Mais uma vez, homem e animal se fazem um só, espécie de corpo contínuo que excede os limites primeiros de cada corpo particular. Hemingway, ele próprio, evidencia a existência desse novo e estranho corpo, uma vez que o peixe passa a arrastar todo aquele conjunto até zonas muito distantes da terra. A partir daí, perde-se a certeza 
da própria localização, ainda que Santiago intua não estar tão longe a ponto de não poder mais voltar. A estrutura desse corpo-sem-órgãos é muito frágil, porque é pesada e mantida exclusivamente a custo da força e astúcia de Santiago: até o fim, o objetivo do personagem - matar o peixe e levar seu corpo até a ilha - só poderá se cumprir se eles permanecerem ligados.

Daí que as linhas sejam elemento crucial na novela, o texto abunda em linhas em toda sua extensão. O narrador descreve linhas fibrosas nos braços de Santiago, linhas de corte feitas nos dorsos dos peixes abertos pelo Velho, linhas de correntes marítimas, linhas de circulação de peixes e aves. O grande peixe fará grandes linhas em círculo nas profundezas, tentando escapar do Velho. As mais importantes são as linhas de pesca e de morte: aquelas feitas pela vara e pelo arpão de Santiago. A linha de pesca é parte do corpo-sem-órgãos do texto, as linhas verticais, feitas pelo movimento do arpão de cima para baixo, são aquelas que matam o peixe e os tubarões que logo aparecem. Há linhas mesmo na cabeça desses tubarões. Na verdade, diz o narrador: "essas linhas não existiam... Mas o cruzamento dessas linhas imaginárias determinava a localização do cérebro". Podemos discordar de que elas "não existiam", essas são linhas de intuição; poder vê-las é o que permite que Santiago tenha chegado até essas zonas de desterritorialização. Não é por acaso que o grande herói de Santiago seja um jogador de baseball, a quem chama de o "grande Di Maggio". O baseball é também um jogo de linhas, no qual vence o time que melhor organiza os movimentos nelas.

A última linha da novela vai traçar uma territorialização desde o lugar onde ocorreu o primeiro ataque de tubarão até a praia, feita com o sangue do peixe que se espalha nas águas do mar. Novos tubarões vão surgir nesse trajeto, atraídos pelo sangue que se espalha como uma nuvem roxa no mar. Os mais importantes são os chamados de galanos que, ao contrário do primeiro, não têm beleza alguma. São fedorentos, feios, idosos, cruéis e, diz o narrador, comeriam um homem vivo, mesmo que ele não estivesse sangrando. Já foi buscada uma leitura alegórica dos tubarões galanos como os fascistas que aparecem em Por Quem os Sinos Dobram, tendo como referência a comparação feita por Jordan e Anselmo entre os caças da Luftwaffle e grande tubarões. Contudo, nem os fascistas do 
romance são descritos da mesma maneira que esses tubarões galanos. Ainda, os sentidos são invertidos entre o romance e a novela para a aparição desses "tubarões".

Em Por Quem os Sinos Dobram, o narrador diz que: "the shadows of the Heinkels moving over the land as the shadows of sharks pass over a sandy floor of the ocean ${ }^{140}$." Em $O$ Velho e $O$ Mar, o personagem não se encontra por baixo dos tubarões, mas acima deles. A diferença entre essas imagens literárias é significativa, na medida em que o sentido da narrativa no romance é de um horizonte de expectativas fechado: os personagens observam os caças nazistas circulando no céu como pequenos peixes observariam os tubarões circulando em águas mais rasas. A perspectiva do romance é sempre de baixo para cima, o que oferece uma visão bem mais sufocante. Santiago, pelo contrário, é plenamente capaz de lutar com os tubarões, apesar de não se tratar daquilo que chamamos de combate na natureza, quando o personagem sai transformado de sua luta. Como o homem e o peixe formam um só corpo, cada mordida que os tubarões dão nesse corpo é sentida como se fosse no próprio Santiago: "Amava o peixe quando estava vivo, afinal ainda o ama morto".

Daí que, ao matar os primeiros tubarões, as reflexões de Santiago transitem para a ética de matar. Diz ele que "tudo mata tudo de uma maneira ou de outra. Pescar mata-me tal como me faz viver". A questão que ele se coloca é que seria também um pecado ter matado o peixe, já que o amava ou se o fato de amar suas pescas o imiscui do pecado de matar. Esse tema já havia sido visitado em diversas passagens Por Quem os Sinos Dobram; no romance, não se busca justificação no mundo natural, mas no vazio moral deixado na humanidade durante a Guerra Civil Espanhola. O que se perguntam os personagens é se haveria ainda valores que deveriam guiar suas condutas, cuja resposta é claramente negativa: Pilar cospe nas bandeiras dos próprios movimentos pelos quais luta, porque perdera a crença na superioridade moral de sua causa (a republicana) depois da chacina que seu bando conduziu contra proprietários, padres e fascistas de um vilarejo. Anselmo perdeu a sua crença em Deus e, portanto, não imagina mais a possibilidade de ser perdoado - daí que acredite que 
seja pecado matar tanto ursos quanto homens, ainda assim vai matar na guerra, caso seja preciso. Rafael incita Jordan a matar Pablo enquanto ele está distraído, porque seria mais fácil, ainda que fosse mais covarde. $\mathrm{O}$ mundo do romance lida com uma tensão de um vácuo na escala de valores, em que "não matar" pode ter o sinal invertido a qualquer momento, dependendo de circunstâncias contingentes. Matar um parceiro de guerrilha poderia parecer alta traição ou um imperativo em favor da causa, dependendo de cada perspectiva. Daí que esses personagens possam olhar ao chão e ver as sombras dos caças Heinkels como se estivessem no fundo de um mar dominado pelo fascismo: elas aparecem como uma confirmação de que a vitória já era impossível.

Ernest Hemingway atuou na Guerra Civil Espanhola de forma indiscreta pelo lado republicano, trabalhando como correspondente para revistas e jornais norte-americanos, mas também produziu o roteiro para o documentário The Spanish Earth (1937), que seria usado como motor para arrecadações, nos Estados Unidos, para o lado republicano do combate, que, a essa altura, já estava em vias de ser controlado pela União Soviética ${ }^{141}$. Tanto no romance quanto no documentário, é visível a preocupação de Hemingway de aproximar o leitor/espectador dos corpos dos personagens mobilizados; em Spanish Earth, a câmera aproxima-se dos rostos suados, queimados de sol e, às vezes, cobertos de pó dos espanhóis republicanos. É evidente a aproximação que fazem romance e documentário entre a luta dos espanhóis e a terra na qual habitam, tornando-se secundária, ou até ausente, o valor liberal da propriedade. De forma geral, todos os personagens dessas duas obras lutam para poder continuar a habitar suas terras, movimentarem-se livremente entre os territórios que habitam tradicionalmente. São duas obras, evidentemente, marcadas pela política, mas que evitam discutir o tema da política institucional. Nelas, a presença soviética se traduz em força material e disciplina organizativa - se bem que essa disciplina não venha sem uma máquina burocrática/paranoica, evidenciada nos altos escalões -, mas não está presente uma luta comunista. Para Gisele Beiguelman, o devir-revolucionário na obra de Hemingway deriva ainda dos motivos da Revolução Americana ${ }^{142}$; de

141 BEIGUELMAN, Giselle. A República de Hemingway: por quem os sinos dobram?, São Paulo: Perspectiva, 1993.

142 Idem, Ibidem. 
fato, é crucial o papel que a Guerra de Secessão toma a certa altura de Por Quem os Sinos Dobram, quando Robert Jordan vê-se dividido entre duas heranças genéticas: a bravura do avô, herói da Guerra de Secessão, e a covardia do pai, que viu no suicídio um caminho mais fácil para escapar de seus problemas.

O tom político, diretamente político, não se apresenta da mesma forma em $O$ Velho e $O$ Mar. O que marca como continuidade entre aquele romance e essa novela é a fratura do Sujeito dos protagonistas: suas ações e seus pensamentos são acompanhados por duas vozes. Aquela vocalizada pelo protagonista é sempre marcada pela incerteza, ela expressa as fraquezas e dúvidas do personagem, diante da impossibilidade de estabelecer um sentido único e seguro na avaliação dos mais simples passos. A segunda voz, que surge como a voz de Deus no texto do Velho Testamento (sem um corpo que a encarne), é sempre imperativa. Os personagens não estão delirando ao ouvi-las. É, de fato, compreensível a sua expressão nos dois textos, uma vez que somente enquanto Sujeito fraturado, Robert Jordan ou Santiago poderiam disciplinar seus afetos até o fim de seus objetivos. Enquanto a primeira voz duvida de si mesmo, a segunda ordena que ele seja nada mais que um instrumento do seu dever ("You are instruments to do your duty"). Enquanto engrenagem da máquina de guerra, Jordan precisa disciplinar não apenas sua mente, mas também seu corpo. Similar à forma como a voz imperativa funciona em Santiago: ela é disciplinadora da mente e do corpo, cujas dores precisam ser ignoradas no momento em que ele luta para não perder o peixe.

Em um romance de 2009, Leonardo Padura - leitor e admirador de Ernest Hemingway - descreve a formação do tipo de guerrilheiro de elite que participara da Guerra Civil Espanhola como alguém, cujo $\mathrm{Eu}$ fora destroçado pelo intenso treinamento soviético, cujo objetivo era a canalização de qualquer pulsão em direção aos objetivos da missão designada. O guerrilheiro perfeito, segundo $O$ Homem Que Amava Os Cachorros ${ }^{143}$, não tem desejos. No romance de Hemingway, essa não é a condição de Robert Jordan, mas isso não torna a descrição interna do personagem menos interessante do que em Padura: Jordan ainda é capaz de ter desejos e de fantasiar, e esses movimentos não são apenas negativos na condução de sua missão. Salienta-se, mais de uma vez, a necessidade

143 PADURA, Leonardo. O Homem Que Amava Os Cachorros. São Paulo: Boitempo, 2015. 
dos guerrilheiros permanecerem felizes, caso contrário, a tendência é de que traiam a missão. Vejamos o exemplo de Pablo, o ex-líder do bando ao qual se junta Robert Jordan, que, ao perder as esperanças, quase entrega o grupo de personagens nas mãos dos fascistas. A disciplina ainda rege a conduta de Jordan, mas ela será abalada nos eventos em que o seu desejo fala mais alto do que a concentração estrita nos planos da missão. Fica claro que, entre seus desejos e afetos (que podem desviá-lo da missão), e a disciplina rígida que a voz imperativa dentro dele reclama, é o Eu de Robert Jordan que é torturado até os limites.

Um dos efeitos dessa condição fragmentada é a paranoia, essa sim completamente ausente em $O$ Velho e $O$ Mar. Parece possível apontá-la como um efeito da presença da máquina burocrática ${ }^{144}$ de guerra do romance, ausente na novela. Tal constatação pode ser justificada por meio de uma breve análise de um personagem marginal, no entanto, significativo para se entender o sentido da máquina burocrática enquanto máquina paranoica. Trata-se do general Marty, pertencente ao alto comando do exército soviético-comunista, do qual se dizia estar louco: "Está loco... He is crazy". Mas essa loucura tem, na verdade, uma saída muito específica: a paranoia, correndo contra qualquer verossimilhança factual, faz com que o general Marty prenda os dois guerrilheiros do bando de Jordan que levavam informações sobre as linhas inimigas, cruciais para a condução da missão. Assim é que o general Marty traça sua linha de raciocínio:

\footnotetext{
"Golz", pensou ele, numa mistura de horror e exultação, como sente um homem ao ouvir que o inimigo foi morto num acidente de carro horrendo, ou que alguém odiado, mas de cuja honradez nunca ninguém duvidou, é culpado de um desfalque. "Aquele Golz deve ser um deles, também. Aquele Golz deve estar em contato com os fascistas. Golz, que ele conhecia há cerca de vinte anos. Golz, que capturara o trem de ouro, naquele inverno, com Lucacz na Sibéria. Golz, que lutara contra Kolchak, e na Polônia. E no Cáucaso. Na China, e aqui, desde outubro. Mas ele era próximo de Tukachevsky. De Voroshilov, sim, também. E de quem mais? Aqui, de Karkov, naturalmente. E de Lucacz. Mas todos os húngaros eram intrigueiros. Ele odeia Gall. Golz odeia Gall. Lembre--se disso. Tome nota. Golz sempre odiou Gall. Mas ele favorece. Putz. Lembre-se disso. E Duval é o seu chefe do estado-maior. Veja o que provém daí. Você já ouviu ele dizer que Copic é um idiota. Isto é definitivo. Isto é real. E agora este despacho das linhas fascistas. Somente podando os ramos secos
}

144 "Máquina burocrática" como aquela identificada por Deleuze e Guattari na literatura de Franz Kafka (DELEUZE, Gilles \& GUATTARI, Félix. Kafka: por uma literatura menor. Belo Horizonte: Autêntica, 2017). 
se pode preservar a saúde da árvore e fazê-la crescer. Mas os ramos secos devem aparecer para que sejam destruídos. Golz, dentre todos os homens. Golz deve ser um dos traidores. Não se pode confiar em ninguém. Ninguém. Jamais. Nem na sua esposa. Nem no seu irmão. Nem no seu mais antigo camarada. Em ninguém. Jamais ${ }^{145}$.

Nessa dissociação entre realidade e discurso interno - vemos que ele divaga de forma perdida, juntando os fragmentos de modo a tecer uma teoria conspiratória inexistente - o que está em jogo aqui não é a condição patológica individual de um indivíduo do alto-comando. O que fala, através do personagem, é a própria máquina burocrática, como bem perceberam Deleuze e Guattari em sua análise sobre Kafka ${ }^{146}$, que se compõe por blocos e segmentos que não param de criar conexões, a fim de se reproduzir. Quanto mais alto - ou seja, mais dentro da máquina burocrática, maior a presença do seu próprio discurso na voz do personagem. Até porque não é apenas o general Marty quem a reproduz, mas o próprio general Golz (a quem Marty atribui a conspiração fascista) que aparece no romance com discursos marcados pela paranoia.

A importância do general Marty não está em si mesmo, mas na conexão possível entre a sua paranoia e a de Robert Jordan. Afinal, também o protagonista - na sua fragmentariedade - tem traços paranoicos em seu discurso, uma vez que o tempo todo busca fazer dos fragmentos da realidade, que sua consciência é capaz de perceber, um discurso totalizador, capaz de definir os planos de ação. Por exemplo, quando invoca a oposição do fragmento-pai com o fragmento-avô - o primeiro, um covarde, e o segundo, um herói da Guerra de Secessão, - a

145 Tradução de: "Golz, he thought in a mixture of horror and exultation as a man might feel hearing that a business enemy had been killed in a particularly nasty motor accident or that some one you hated but whose probity you had never doubted had been guilty of defalcation. That Golz should be one of them, too. That Golz should be in such obvious communication with the fascists. Golz that he had known for nearly twenty years. Golz who had captured the gold train that winter with Lucacz in Siberia. Golz who had fought against Kolchak, and in Poland. In the Caucasus. In China, and here since the first October. But he had been close to Tukachevsky. To Voroshilov, yes, too. But to Tukachevsky. And to who else? Here to Karkov, of course. And to Lucacz. But all the Hungarians had been intriguers. He hated Gall. Golz hated Gall. Remember that. Make a note of that. Golz has always hated Gall. But he favors Putz. Remember that. And Duval is his chief of staff. See what stems from that. You've heard him say Copic's a fool. That is definitive. That exists. And now this dispatch from the fascist lines. Only by pruning out of these rotten branches can the, tree remain healthy and grow. The rot must become apparent for it is to be destroyed. But Golz of all men. That Golz should be one of the traitors. He knew that you could trust no one. No one. Ever. Not your wife. Not your brother. Not your oldest comrade. No one. Ever.” (HEMINGWAY, Ernest. op. cit., 2003, p. 402).

146 DELEUZE, Gilles \& GUATARRI, Félix. op. cit., 2017. 
consciência de Jordan produz uma narrativa sobre ele mesmo, mostrando-o na sua própria covardia e coragem. Aquilo que o historiador americano Hayden White escrevera sobre as técnicas narrativas de produção de sentido histórico ${ }^{147}$, num plano geral, vale também para a consciência de Jordan: a luta do seu Eu fraturado, dividido pelas contradições entre o sentido de dever (levar até o fim a missão designada, o que vai certamente matá-lo) e pelos seus desejos (de fugir, de ficar com Maria e de continuar vivo), dá-se por meio da produção de uma narrativa que possa produzir, a partir do apanhado desses fragmentos contraditórios, uma unidade compreensível. Não é por acaso que Hemingway concentra "todo o destino da Humanidade" 148 num objeto tão aparentemente ordinário, como a ponte que deve ser explodida por Jordan e os guerrilheiros.

Como K., os camponeses, os funcionários e a aldeia inteira fazem parte do Castelo no romance de $\mathrm{Kafka}^{149}$, também todo o conjunto de personagens em Por Quem os Sinos Dobram faz parte da máquina burocrática soviética, assim como essa se associa à máquina fascista. Isso configura o horizonte de expectativas fechado do romance, no qual cada esperança parece vã à sombra dos grandes caças nazistas, da consciência da falta de organização e organicidade dos guerrilheiros republicanos; e, em poucos momentos, é aliviada a angústia gerada pela escalada de indicadores do fracasso da missão, o que significaria uma morte sem heroísmo para Jordan. Em um deles, opera-se, mais uma vez, um corpo-semórgãos, dessa vez, entre o protagonista e a personagem Maria.

Até esse romance, o amor aparecera na literatura de Ernest Hemingway como um jogo podre (rotted game); bastaria pensar nas relações dos personagens masculinos com Brett Ashley, entre Henry e Barkley ou nas relações amorosas presentes no contos do mesmo período. Nesse romance de 1940, o amor aparece não mais como uma forma de dominação simplesmente, mas como potência. Hemingway indica essa direção ao descrever o ato sexual entre Jordan e Maria da seguinte a maneira:

Então foi o cheiro da urze esmagada e a aspereza dos galhos curvados sob a cabeça dela, com o sol brilhando nos seus olhos cerrados, e para

147 Ver, por exemplo, o capítulo introdutório de Trópicos do discurso: ensaios sobre a crítica da cultura. São Paulo: Edusp, 1994 e Meta-história: a imaginação histórica do século XIX.

148 HEMINGWAY, Ernest. op. cit., 2003, p. 43.

149 DELEUZE, Gilles \& GUATTARI, Félix. op. cit., 2017. 
o resto de sua vida ele iria lembrar da curva da garganta dela, da sua cabeça jogada para trás, no meio das raízes das urzes, e seus lábios movendo-se pequenos, irrequietos, o bater dos cílios sobre os olhos fechados contra o sol e contra tudo o mais, para ela tudo era avermelhado, laranja, ouro e vermelho, por causa do sol batendo-lhe nos olhos fechados, tudo tinha aquelas cores, tudo, o preenchimento, a posse, a fruição, tudo tinha aquelas cores, tudo uma cegueira com aquelas cores. Para ele era uma passagem escura para lugar nenhum, depois para lugar nenhum, e novamente para lugar nenhum, e mais uma vez, sempre para lugar nenhum, pesado sobre os próprios cotovelos fincados na terra, para lugar nenhum, escuridão, nunca um final, sempre dando em lugar nenhum, preso todo tempo sempre a nenhum lugar insabido, agora e de novo para sempre e para lugar nenhum, não para nascer de novo, agora, mas, mais uma vez, para nenhum lugar, agora, além de toda resistência, indo e indo para lugar nenhum de repente, escaldante, um amparo, todo o nada se esvaiu e o tempo de todo parou e os dois lá, o tempo parado, e ele sentiu a terra mover-se e fugir debaixo deles ${ }^{150}$.

Ou seja, apenas o amor em seu ato mais corpóreo - pois, como tudo na literatura de Hemingway, é preciso que os afetos manifestem-se corporalmente para que sejam verdadeiros - é capaz de fazer calar, não só aquela voz imperativa que o empurra ao cálculo utilitário de si mesmo e dos outros personagens para a missão, mas também todo o mundo ao seu redor. Na descrição daquele ato, perdese de tal forma o mundo para os personagens que a própria linguagem que os descreve perde o sentido objetivo. Desnaturam-se noções de tempo e espaço e percepções sensíveis. Em troca, contudo, há uma espécie de renaturalização desse amor nos momentos seguintes, e Jordan passa, então, a imaginar uma vida normalizada com Maria como sua esposa. Mesmo dentro dessa imaginação, ela se prova falsa (quando Jordan imagina-se um professor universitário de língua espanhola, reunindo seus alunos, e Maria contando-lhes como os solados fascistas a estupraram), fechando, mais uma vez, o circuito de afetos ${ }^{151}$ do romance.

150 No original: "Then there was the smell of heather crushed and the roughness of the bent stalks under her head and the sun bright on her closed eyes and all his life he would remember the curve of her throat with her head pushed back into the heather roots and her lips that moved smally and by themselves and the fluttering of the lashes on the eyes tight closed against the sun and against everything, and for her everything was red, orange, gold-red from the sun on the closed eyes, and it all was that color, all of it, the filling, the possessing, the having, all of that color, all in a blindness of that color. For him it was a dark passage which led to nowhere, then to nowhere, then again to nowhere, once again to nowhere, always and forever to nowhere, heavy on "the elbows in the earth to nowhere, dark,' never any end to nowhere, hung on all time always to unknowing nowhere, this time and again for always to nowhere, now not to be borne once again always and to nowhere, now beyond all bearing up, up, up and into nowhere, suddenly, scaldingly, holdingly all nowhere gone and time absolutely still and they were both there, time having stopped and he felt the earth move out and away from under them." (HEMINGWAY, Ernest. op. cit., 2003, p. 159).

151 Pode-se objetar o uso do conceito "circuito de afetos" na análise literária, mas aqui seu uso pareceu ter sentido; seu uso original é, contudo, político (SAFATLE, Vladimir. O circuito dos 
Em $O$ Velho e $O$ Mar, a novela não restitui um território para o qual Santiago pode retornar. Desde aquela última linha traçada pelo sangue do peixe no mar, não se trata de recuperar uma posição de grandeza entre os homens através do esforço, mas de perder-se a si mesmo nessa busca pelo impossível: não é à toa que Santiago volte como uma carcaça, assim como seu peixe.

Nosso esforço de leitura foi para reconhecer um devir-revolucionário ${ }^{152}$ nesse retorno: no seu tamanho descomunal, a carcaça do peixe prova a potência que necessária para que ele fosse vencido. Portanto, aqueles que vão até a praia ver o corpo de Santiago deitado ao lado dela reconhecem que essa potência existiu também através do próprio velho, considerado pela comunidade de personagens como a manifestação de uma chaga.

Muito diferente é o destino de Robert Jordan em Por Quem os Sinos Dobram: desde o início, - ou melhor, ao menos desde que Pilar lê sua mão - o leitor (e ele mesmo) é direcionado para uma perspectiva, cujos horizontes de expectativa estão cerrados. Não apenas o grupo de guerrilheiros sairá derrotado, como nas previsões mais pessimistas de Pablo, como também morrerá Jordan, terminando sem Maria e sem a vitória. Ainda que a carcaça de Santigo tenha sido devorada pelos tubarões, é possível tirar duas conclusões diversas ao final desses dois textos, cuja diferença não parece irrelevante politicamente: o destino de Jordan confirma a própria perspectiva do romance (os personagens olhando de baixo os caças fascistas, conscientes de que não escaparão deles); a derrota de Santiago, como diz Beckett, é melhor. Ele rasga os limites imaginativos, quando pesca um peixe como ninguém até então havia visto.

afetos. Belo Horizonte: Autêntica, 2015.

152 Mais uma vez, referência aqui a Deleuze e Guattari, mais especificamente ao quarto volume de Mil Platôs. 


\section{The way to Hemingway: os problemas da recepção cubana}

\section{1 - Introdução}

O escritor cubano e futura persona non grata em sua ilha de origem, Guillermo Cabrera Infante, a certa altura de Corpos Divinos ${ }^{153}$, relembra uma tarde em que tentava impressionar uma modelo estrangeira com o fato de conhecer Ernest Hemingway e, inclusive, saber onde o escritor americano morava. Ela lhe pergunta insistentemente "Do you know Hemingway?", até que se convence, quando Infante a convida para fazer uma visita ao escritor, chamando o trajeto que leva até sua casa de "the way to Hemingway".

Esse livro de Cabrera Infante está recheado de imagens pouco iconoclastas do escritor americano: errando um soco cruzado num bar de Havana ou urinando bêbado no mar, a bordo de seu barco Pilar, durante a filmagem de uma adaptação de $O$ Velho e $O$ Mar. Mas a passagem mais interessante ocorre num momento posterior à Revolução Cubana, ao qual faremos referência daqui a algumas páginas.

Esta dissertação buscou ser, ao seu modo, também um "caminho até Hemingway". A obra e, principalmente, a vida desse escritor são compostas por tantos caminhos que seria impossível mostrá-los todos. Isso nunca esteve entre nossos objetivos, mas tampouco poderíamos cobrir completamente a extensão daqueles que investigamos. O trajeto que leva de $O$ Sol Também Se Levanta até $O$ Velho e $O$ Mar é muito mais amplo e possui muito mais ramificações do que aquilo que foi apresentado nos últimos capítulos. Ainda assim, nosso texto pode atravessar alguns deles, traçando uma linha que vai de Oak Park até Cuba, atravessando Paris e a Espanha. E, ainda que esses diferentes territórios pudessem ter sido explorados mais longamente, nos interessava aqui mais o esforço inicial de produzir relações entre eles. Analisar alguns dos contos de In our time, assim como os romances $O$ Sol Também Se Levanta, Por Quem os Sinos Dobram e $O$ Velho e O Mar foi nossa forma de traçar essa linha inicial.

153 INFANTE, Guillermo Cabrera. Corpos Divinos. São Paulo: Companhia das Letras, 2016. 
Neste capítulo, desejamos demostrar como o "caminho até Hemingway" extravasa os limites de sua obra e vida. Para isso, vamos recorrer a duas (das muitas) representações do autor, uma do citado livro de Guillermo Cabrera Infante e outra do filme Memorias del subdesarollo, de Tomás Gutiérrez Alea. Isso nos servirá menos para a leitura que foi feita dos textos de Hemingway em Cuba e mais para apresentar ramificações e usos feitos a partir de sua obra e imagem. Consideramos relevante a forma como Hemingway aparece para esses dois artistas, uma vez que Cuba teve espaço destacado dentro de sua vida e foi o ambiente de seus dois últimos livros.

\section{2 - Adeus, Hemingway}

A última passagem em que Guillermo Cabrera Infante relembra Hemingway em Corpos Divinos não poderia ser mais significativa: ela narra a vitória de Fidel Castro sobre o escritor num de seus esportes favoritos, a pesca. Não qualquer pesca, mas a pesca do peixe-espada em águas cubanas, que estará ligada à figura de Hemingway enquanto ainda circularem exemplares de $O$ Velho e O Mar. Castro vira-se para Hemingway, "Mister Way!", mostrando-lhe um grande peixe, maior que o dele, vitorioso naquele embate tão importante para o velho escritor. Para Guillermo Cabrera Infante, estava claro que:

Fidel Castro não se deixaria vencer por ninguém, muito menos por um escritor que combatera - ocasionalmente - na Guerra Civil espanhola, que dizia conhecer a arte da guerra de guerrilhas, que fora um correspondente muito ousado da Segunda Guerra Mundial e que antes, muitos anos antes de Fidel Castro ser concebido, dirigira uma ambulância no front italiano ${ }^{154}$.

A passagem é seguida por uma comparação homérica entre essas duas figuras: Castro é um Xenofonte cubano, cujo rosto é coberto por uma barba escura, cheia e mediterrânea, astuto e cruel como Aquiles, ainda mais alto que o escritor. Hemingway contrasta, mais largo e robusto, com sua pele mais clara e barba e cabelos muito brancos. A pequena passagem, de pouco mais de duas páginas, termina com uma conclusão típica de seu autor (ou seja, política, ainda que evite ao máximo demonstrá-lo):

154 INFANTE, Guillermo Cabrera. op. cit.,p. 559-560. 
Até agora ele fora o homem mais famoso do mundo a viver em Cuba: Ernest Hemingway of Finca Vigia. A partir desse momento, reconhecia estar cedendo o terreno a Fidel Castro, o homem mais famoso nascido em Cuba nesse século. Essa dupla diferença (nascido em Cuba, nascido nesse século) era o único consolo para o perdedor que não leva nada ${ }^{155}$

Apesar de que o temor pelo futuro do movimento ainda estivesse presente, uma vez que ainda existiam batistianos e contrarrevolucionários na ilha, a Revolução Cubana, conduzida por Che Guevara e os irmãos Castro, já era claramente vitoriosa nessa altura das memórias de Infante. Nas suas últimas referências ao escritor, Infante comenta o fato de que seu sorriso já não passava de uma careta torta: Hemingway, há anos, recebia tratamento por eletrochoque e, poucos anos depois, se suicidaria. Independente do grau de ficcionalidade do relato destacado acima, o que nos interessa é reconhecer como a figura de Hemingway vai ser trabalhada, depois da Revolução, pela imaginação cultural de alguns de seus leitores mais importantes.

Ainda vale dizer um pouco sobre a importância de Hemingway para a formação literária de Guillermo Cabrera Infante. Numa entrevista de $1995^{156}$, dois anos antes de receber o Prêmio Cervantes, o escritor diz que havia parado de ler em espanhol nos anos 1960, porque se interessava muito mais prelos de língua inglesa. Ele se referia primeiramente a Hemingway e Faulkner, e não a Borges ou outros escritores latino-americanos, como suas influências.

Em um breve artigo, o pesquisador Terry J. Peavler ${ }^{157}$ mostra como In Our Time (1924), a primeira obra ficcional de Ernest Hemingway, é um modelo para Así em la paz como en la guerra (1960), uma coleção de esquetes e contos que investiga a violência desde os tempos pré-colombianos até o meio do século XX cubano, obra também de estreia de Infante. A violência, - na verdade, a forma como a linguagem é capaz de representá-la de forma imediata e crua, - é a marca maior desse livro de Ernest Hemingway. Bastaria pensar em Up in Michigan (Lá no Michigan), conto que abre o livro, no qual uma jovem é estuprada pelo homem

155 Idem, Ibidem, p. 561.

156 A entrevista citada está reproduzida em formato podcast, disponível na plataforma digital Spotify: The Kitchen Sisters Present - ep. 87: Guillermo Cabrera Infante: memories of a invented city. Disponível em: https://open.spotify.com/episode/7Egj841c8lbYY1EPmgyr3O. Acesso em: 20 fev. 2021.

157 PEAVLER, Terry. Guillermo Cabrera Infante's Debt to Ernest Hemingway. Hispania, MaySep., 1979, v. 62, n. 3 (May-Sep., 1979), p. 289-296. 
por quem está apaixonada (Getrude Stein recomendara muito que Hemingway desistisse da publicação desse conto, pois a sua linguagem era demasiadamente imoral e descrições como aquela não pertenciam à literatura ${ }^{158}$ ).

O trabalho de Peavler é minucioso e mostra como Cabrera Infante se apropria da técnica heminguiana para desenvolver uma estética literária que aproximou a linguagem havanesa falada e o espanhol formal. A literatura, normalmente, exige do escritor uma proximidade com sua língua materna e com aquela do Estado sob o qual vive, o que torna essa boa apropriação uma exceção.

Quando escreveu Tres Tristes Tigres ${ }^{159}$ (1965), Cabrera Infante operou justamente aquilo que Deleuze elogia como língua menor ${ }^{160}$, ou seja, perfura o espanhol oficial com o havanês inculto e falado. Ao mesmo tempo, já nessa época, estava mais interessado no que se escrevia em inglês do que qualquer coisa em espanhol, embora vindo da América Latina. Na referida entrevista de 1995, declara que, para sua formação como escritor, não houve tradição literária latinoamericana alguma ${ }^{161}$.

Há movimentos na literatura de Hemingway semelhantes ao que fizera Cabrera Infante em Tres Tristes Tigres. Já no uso que Hemingway faz do inglês em $O$ Sol Também Se Levanta, o escritor procura ir minorando todas as sentenças, até que a linguagem escrita seja tão direta e pouco sofisticada quanto o inglês falado, principalmente aquela linguagem elaborada em Por Quem os Sinos Dobram, que atravessa lugares incertos, nos quais se produziu uma língua que não é nem bem inglês, nem espanhol. É justamente através dessa estranheza, e não apesar dela, que a linguagem se torna comunicável entre aqueles personagens tão diferentes, nacional e culturalmente.

É ainda importante chamar atenção para aquilo que ocorria fora do estritamente literário, ou seja, para o contexto cultural que envolve essa apropriação por parte de GCI (ao ler suas memórias, temos a impressão, ao ler

158 HEMINGWAY, Ernest. Paris é uma festa. Rio de Janeiro: Bertrand Brasil, 2020, p. 29-30.

159 INFANTE, Guillermo Cabrera. Três Tristes Tigres. Rio de Janeiro: José Olympio, 2009. Ainda sobre TTT, ver o comentário de PEAVLER, op. cit., 1979.

160 DELEUZE, Gilles \& GUATTARI, Félix. Kafka: por uma literatura menor. Belo Horizonte: Autêntica, 2017.

161 A entrevista citada está reproduzida num podcast disponível em plataformas digitais (The Kitchen Sisters Present - ep. 87: Guillermo Cabrera Infante: memories of a invented city. Disponível em: https://open.spotify.com/episode/7Egj841c8lbYY1EPmgyr3O). Acesso em: 20 fev. 2021. 
suas memórias, de que pode ter sido ainda mais importante para suas narrativas do que a própria literatura). O primeiro bloco da literatura de Hemingway - aquele que cobre a década de 1920 - poderia ser pensado não só a partir dos processos de fragmentação que foram expostos nesta dissertação, mas também em diálogo com os processos de minoração, fragmentação e aceleração da música (pensando aqui na emergência do jazz), e das inovações técnicas do cinema ${ }^{162}$.

Quando escritores como Hemingway ou Cabrera Infante investigam, em suas literaturas, a vida cultural de Paris dos anos 1920, ou da Havana dos anos 1950, eles elaboraram a vida de seus personagens a partir de contextos similares: tanto em O Sol Também Se Levanta quanto em Corpos Divinos, encontramos um narrador imerso num tipo vida boêmia, apreendendo sua cidade enquanto território fragmentado; experimentando a literatura de forma igualmente fragmentária (GCI, na citada autobiografia, lê seus livros aos pedaços, assim como Jacob Barnes lê, completamente bêbado, Turgueniev em seu Hotel em Pamplona). Há quase uma convergência nesses dois territórios, de modo que seus narradores só podem experimentar suas próprias vidas fazendo referência à arte (no caso, à literatura, ao cinema e à música). O historiador Modris Eksteins, no seu livro A Sagração da Primavera: a grande guerra e o nascimento da era moderna $^{163}$, já havia percebido que, longe de significar um afastamento da arte em relação à vida, processo de autonomização estética que envolvia o contexto cultural depois da Primeira Guerra na Europa (ou seja, aquele acreditamos ter extravasado as fronteiras europeias e encontrado uma de suas ramificações na Havana de GCI), torna as barreiras entre arte e vida muito mais porosa no século XX. Daí que a emergência de artes como o cinema e o jazz no último século aparecem nessas duas narrativas às quais fizemos referência anteriormente, de maneira a misturar-se com a própria vida da cidade e de seus personagens.

A vida desses dois autores tem lugar especial para o cinema, sendo evidente que GCI estabelece com a sétima arte uma relação ainda mais direta. Sua carreira foi baseada, além de literatura e jornalismo cultural, em crítica

162 Não poderemos levar adiante esse argumento aqui, contudo, sobre o processo de aceleração trazido pelo jazz, sua base sociológica e sua crítica, ver a discussão iniciada em ADORNO, Theodor. On jazz. Discourse v. 12, n. 1, A Special issue on Music (Fall-Winter 1989-90), pp. 45-69; sobre cinema ver DELEUZE, Gilles op. cit., 2018.

163 Ver o primeiro capítulo do livro. 
cinematográfica para a revista Carteles. Mas, como o demonstra o papel destacado de Ernest Hemingway na produção de Spanish Earth, - em que ultrapassou em muito o papel de roteirista - evidencia que o escritor americano também buscou se envolver com cinema, para além de ser mero espectador ${ }^{164}$. Em Corpos Divinos, a aparição mais longa de Hemingway é durante a filmagem de uma adaptação de $O$ Velho e $O$ Mar. Nesse mesmo livro, a música moderna - e, consequentemente, a relação entre música e literatura - já aparece como presença marcante da vida cultural de Havana, de modo que o ponto alto da vida noturna da cidade, assim como surgimento de lojas, cafés, bares e casas de show especializadas em jazz (que, durante o século XX, segundo Hobsbawm, foi a mais vibrante das músicas populares ocidentaii ${ }^{165}$ ) coincide com os anos de recepção da obra de Ernest Hemingway. Não que a coincidência desses processos implique causalidade, mas convergência: de forma similar aos processos que marcam o surgimento das literaturas modernistas (comentados no primeiro capítulo desta dissertação), ao acompanharmos as ramificações da obra de Hemingway nas memórias de Infante, veremos que ela aparece em bloco com outras manifestações estéticas, marcadas igualmente por aqueles elementos de aceleração e superficialização.

Alguns anos depois, com Cabrera Infante já fora da ilha, o diretor Tomás Gutierréz Alea lança Memorias del subdesarollo (1968). O filme se inicia com imagens da noite cubana, uma banda está tocando enquanto um sujeito (desmaiado ou morto) é carregado para fora. A festa continua, até que uma mulher negra olha diretamente para câmera, então, o filme congela no seu olhar. A perspectiva do filme se dá através de Sergio, um aspirante a escritor dissidente da burguesia cubana. Durante todo o filme, ele reflete sobre as contradições que constituem sua nova condição depois da Revolução e sobre o destino de seus desejos, agora que não há mais Batista para se opor.

Entre outras coisas, o filme produz uma crítica ao comportamento mimético que a burguesia cubana possui em relação ao modelo americano; é na figura de sua esposa, - ou ex-esposa, já que ela foge para Miami, - que essa

164 BAKER, Carlos. Hemingway: o romance de uma vida. Rio de Janeiro: Civilização Brasileira, 1971. 165 HOBSBAWM, Eric. História social do jazz. São Paulo: Paz e Terra, 2009. 
mimetização (num sentido copista) se materializa. Ainda que seja irônico e faça da ironia contra sua própria classe um instrumento de crítica, não podemos afiançar que Sergio encontra ou não um lugar para si na Havana pós-revolucionária: olhando de sua janela, a cidade é como um cenário e ele não sabe dizer se é de papelão ou de verdade.

Também Cabrera Infante, numa passagem muito breve de suas memórias, recorre à realidade enquanto cenário, ao comentar que era impossível não ver um personagem próximo de seu ciclo de amizades como se fora feito de papelão, como se pertencesse à Revolução somente enquanto imagem de fundo. Hemingway, ele mesmo, aparece como uma imitação de si mesmo em algumas das passagens de Corpos Divinos.

Mas nem a ironia, nem essa estranha sensação do protagonista de que a realidade não passa de cenário impede que Memorias del subdesarollo investigue assuntos sérios. É interesse que o faça de forma fragmentária, sucedendo imagens que aparecem em companhia da voz de Sergio, que, em parte, julga, em parte, descreve os acontecimentos ligados àquelas imagens. Um ponto nevrálgico é quando aparecem imagens e vídeos ligados aos crimes da ditadura de Batista (o tom utilizado é muito próximo de, senão diretamente inspirado em, Hannah Arendt, em Eichman em Jerusalém ${ }^{166}$ ).

A fragmentariedade é uma técnica explorada como uma abordagem política no filme: por volta do quinquagésimo minuto, quando imagens da nova companheira de Sergio aparecem sucessivamente, combinadas com imagens da própria Havana, o narrador diz: "Esa és una de las señalas del subdesarollo: incapacidad de relacionar las cosas, para acumular experiencia y desarollar". É claro que, ao mesmo tempo, essa crítica é uma marca em diferentes pontos do pensamento latino-americano, na segunda metade do século XX, indo do cinema à economia política, mas que, ao mesmo tempo, contradiz o próprio filme que lhe serve de veículo. Ele mesmo é composto de fragmentos, pedaços de memória do protagonista, de imagens aleatórias da cidade, de histórias dos crimes da ditadura de Batista ou da emergência da Revolução.

166 ARENDT, Hannah. Eichmann em Jerusalém. São Paulo, Companhia das Letras, 1999, p. $307-$ 312. 
Além disso - e aqui chegamos finalmente ao nosso objeto principal de discussão - a fragmentação opera também nas cenas em que o filme discute o legado de Ernest Hemingway em Cuba. A casa - ou seja, a apresentação que o filme elabora da casa - tem em vistas também o seu antigo proprietário, ou seja, o apresenta como um rico escritor, amigo da burguesia. Há uma estranheza na atmosfera daquela casa, da qual os personagens (Sergio e sua companheira) não conseguem escapar. A casa (na verdade, uma pequena mansão, com uma torre de alguns andares, onde Hemingway se instalava para escrever) é composta de animais empalhados, uma vasta biblioteca, o famoso quadro do jovem Balzac e a máquina de escrever, em que Hemingway escrevia, permanecendo sempre em pé. Essas e outras imagens do interior da casa cubana de Hemingway levam a companheira de Sergio a concluir que ela era como qualquer outra casa de americanos em Cuba: "o mesmo cheiro americano".

As reflexões que se iniciam apresentam Hemingway como um usurpador, não só de Cuba e dos cubanos - Sergio pensa que o antigo empregado do escritor, então guia turístico da casa, é como um escravo liberto -, mas também da África e seus animais, da Espanha e sua guerra civil e suas touradas, ou seja: tudo que usou como material literário para seus livros en inglés (destaca Sergio) havia sido primeiro morto. Para Memorias del subdesarollo, Hemingway é uma das últimas figuras do imperalismo norte-americano em Cuba: "Hemingway debió ser un tipo insuportable". Não por acaso, depois da casa de Hemingway, o filme passa para uma discussão entre intelectuais sobre a questão da dependência no espaço cultural latino-americano e suas consequências. É também no mesmo quarto em que Hemingway usava como escritório de trabalho que Sergio se esconde, covardemente, de sua nova companheira cubana - de quem já parece estar cansado.

Duas imagens de Hemingway: a primeira de uma decadência ainda honrável, ao ser vencido na luta/pesca contra o novo pretendente ao título de cidadão mor de Cuba, Fidel Castro; a segunda, a de um perverso usurpador, "tipo insuportable" como o próprio imperalismo estadunidense. Qualquer uma das duas mostra, certamente, que Hemingway percorrera um longo caminho, desde uma família puritana no interior do Illinois, seguindo para Paris, atravessando toda a 
vida política e cultural relevante da primeira metade do século $\mathrm{XX}$, indo parar em Cuba, nos últimos anos de dia. Deixou a ilha porque os Estados Unidos cortaram relações com o governo cubano.

Parece interessante alongarmos um pouco a discussão, uma vez que ela nos volta para uma questão que ocupou nossos críticos e historiadores literários mais destacados; quer dizer, poderíamos nos perguntar de que forma essas duas maneiras de lidar com o legado de uma literatura estrangeira servem para pensar a história da cultura latino-americana no século XX. A obra e a posição de Guillermo Cabrera Infante oferece um exemplo de apropriação riquíssimo, mas nega, ao mesmo tempo, a produção latino-americana. Por outro lado, em Memorias del subdesarollo reivindica-se essa tradição, mas isso só é possível ser feito negando tudo que lhe seja externo.

Ainda que não desejemos ingressar nesse debate, parece-nos que experiências como a de Cabrera Infante e seu encontro com a obra de Hemingway demonstram que, menos do que a afirmação da literatura latino-americana enquanto tradição, pode ser interessante pensá-la enquanto atitude diante da linguagem. Essa atitude parece ter em Hemingway um aliado, e uma agenda de pesquisas sobre a recepção da obra de Hemingway, num contexto latinoamericano ou global mais alongado, poderia mostrar as possibilidades geradas por esse encontro. 


\section{Conclusão}

Nossa conclusão vem justificar algumas das escolhas que se fizeram, não apenas neste capítulo, mas também durante toda a dissertação. Primeiro, fica evidente ao leitor que não havia um modelo fixo - ainda que certas leituras da historiografia da literatura fizessem sua influência, de forma mais ou menos consciente na condução da pesquisa -, uma vez que nosso próprio objetivo foi lido como constituído por aquilo que Deleuze chamou de "espontâneo do fragmentário ${ }^{167}$ ". É improvável que esta dissertação sirva para localizar a obra de Ernest Hemingway num lugar específico dentro da história da literatura, como parecem fazer os ensaios de Otto Maria Carpeaux com os autores que discute ${ }^{168}$, mas também não oferece um diagnóstico sobre um bloco de literaturas, como fez Deleuze em Crítica e Clínica a respeito da literatura norte-americana. Ainda assim, tais estudos foram referenciais na composição dos argumentos sobre o cenário cultural ocidental nas primeiras décadas do século XX.

Nosso objetivo era mais como aquele elaborado por Hans Ulrich Gumbrecht em 1926: vivendo no limite do tempo. Estudo que oscila entre uma pesquisa científica e um experimento artístico, recompõe um determinado período histórico, apresentando-o como uma composição de fragmentos.

A dissertação, por motivos variados que vão desde uma preferência por parte de seu autor até limitações impostas durante o período de sua redação, concentrou-se naquela atmosfera cultural e nas ramificações que envolvem o romance $O$ Sol Também Se Levanta. A partir desse livro se guiaram as análises de contos e de outros romances, retratando aquela atmosfera boêmia, acelerada, superficial e tensa que se teve em mente ao reler as memórias de Guillermo Cabrera Infante como uma possível ramificação da narrativa heminguiana. Por ser O Sol Também Se Levanta o livro mais importante, o terceiro capítulo da dissertação, no qual o romance é analisado de forma mais alongada, sendo, portanto, também o mais importante.

167 DELEUZE, Gilles. Crítica e Clínica. São Paulo: Editora 34, 1997.

168 CARPEAUX, Otto Maria. As revoltas modernistas em História da Literatura Ocidental - v.

IV. Brasília: Edições Senado Federal, 2008. 
Em suma: nossa investigação buscou dar ênfase ao caráter fragmentário que caracteriza a técnica narrativa heminguiana, mas também o contexto social do qual ela emerge. Não se trata de uma leitura original do período, ou que sirva exclusivamente ao período e objeto analisados. Já T.J. Clark expusera, em seu estudo sobre a Paris de Manet, que a metrópole havia perdido a possibilidade de ser representada através de uma única imagem, o que resultava não na ausência de imagens, mas numa espécie de inundação de imagens fragmentárias, todas insuficientes para dar cabo da totalidade do fenômeno que representavam ${ }^{169}$. Mas, voltando um pouco mais na história das ciências sociais, um teorizador sistemático como Max Weber também produziu um ensaio metodológico que considera o fragmento, sob o ponto de vista da produção de sentido no texto historiográfico. Diz Weber, nesse ensaio ${ }^{170}$, que é o trabalho do historiador, em grande parte, a reconstrução de um "sentido" no texto, mais do que descobri-lo nos elementos aos quais recorre durante sua investigação.

Também a historiografia e a crítica cultural de Hayden White apresentam reflexões que consideram o problema do fragmento como elemento constituinte da narrativa histórica. Investigar, a partir de obras literárias, memórias ou de investigações historiográficas propriamente factuais, utilizando esses fragmentos textuais dispersos, que, uma vez reunidos, convergem na produção de uma narrativa que simula um todo coerente: essa parece a expectativa legada pela tradição historiográfica à qual recorremos nesta dissertação. Ainda que, mesmo para essa tradição, tal coerência seja fruto mais do trabalho de elaboração textual do investigador do que da realidade concreta. Daí que seja possível encontrar uma convergência entre a historiografia cultural que recorre à dialética (ou seja, ao modelo legado pelos autores discutidos no primeiro capítulo e os textos citados Hayden White no quinto capítulo) e conceito de "bloco de sensações" de Deleuze. O que buscamos apresentar, nesta dissertação, foram "blocos de sensações" historicamente constituídos na obra de Hemingway (talvez à revelia do próprio Deleuze, que desconsiderava explicações "históricas" dos processos de criação).

169 CLARK, T. J. A Pintura da Vida Moderna: Paris na arte de Manet e seus seguidores. São Paulo: Companhia das Letras, 2004.

170 Ver em WEBER, Max. Metodologia das Ciências Sociais. Campinas: Cortez/Editora Unicamp, 1992, p. 193-208. 
Evidentemente, essa estrutura fragmentada incorre em problemas, dos quais esta dissertação não escapa - como a produção de uma trajetória tão improvável quanto Illinois, Paris, Pamplona e Havana (que, contudo, corresponde a uma das trajetórias reais da vida de Ernest Hemingway). As dificuldades, é claro, não provêm apenas do modelo de análise ou do tipo de historiografia às quais recorremos durante a produção deste texto. Muitas das incoerências em que incorremos aqui são fruto das limitações de seu autor, tanto em termos mais práticos e imediatos - como limitação ao acesso às bibliotecas no período mais necessário -, mas também devido ao pouco tempo de experiência com a análise historiográfica.

Nada do que está posto nos últimos parágrafos, porém, busca adiantar as críticas que o texto venha a receber, como numa estratégia de minorizá-las previamente. O leitor desta dissertação terá tantos motivos para criticá-la quanto para reconhecer breves momentos em que ela apresenta algo de interessante. Só que esse tipo de divisão - o que interessa e o que pode ser deixado de lado - já não cabe ao autor. Esperamos apenas que, terminadas essas páginas (que estão longe de ter esgotado qualquer das questões abordadas), seja possível reler a obra de Hemingway de forma distinta. Por menor que sejam seus efeitos, provocar uma leitura diferente de um autor ou de uma obra é o objetivo de um trabalho de crítica ou história literária (ao menos, foi esse o objeto geral desta dissertação).

Termino fazendo referência a outra dissertação sobre Ernest Hemingway, a única que pude encontrar publicada na última década: trata-se do texto de Bárbara Mastrobuono, defendido como dissertação de mestrado na USP ${ }^{171}$. A autora, que teve a gentileza de responder meu contato e indicar leituras, investiga uma espécie de "narração por meio da ausência" - como acusava já seu título - em três contos fundamentais do autor (pude aproveitar parte de sua ideia em um texto que publiquei, por motivos não acadêmicos, num blog de literatura durante a produção desta dissertação ${ }^{172}$ ). Mastrobuono (como eu) deve ter se sentido um pouco como Santiago, e assim como eu, todos vagando sozinhos em alto-mar, agarrados como

171 MASTROBUONO, B. W. A narrativa por meio da ausência: análise de três contos de Ernest Hemingway. Dissertação de Mestrado. São Paulo: Faculdade de Filosofia, Letras e Ciências Humanas, Universidade de São Paulo, 2018.

172 Disponível: http://www.blogletras.com/2020/08/a-superficie-de-hemingway-i-lendo-upin.html. Acesso em: 20 fev 2021. 
estávamos a um peixe (nossos respectivos textos). Numa breve troca de e-mails, ela confirmou minha suspeita de que, além do livro de Giselle Beiguelman, não havia outros estudos acadêmicos, produzidos no Brasil, disponíveis sobre o autor (ainda que não seja impossível que eles existam, estando apenas indisponíveis ou ainda em produção).

A ausência de estudos a respeito do autor no país; implica tanto uma dificuldade quanto uma liberdade relativa: não havendo obras conterrâneas com as quais discutir, tornou-se necessário inventar outras maneiras de lê-lo. Em parte, foi esse o motivo do último capítulo: mesmo que, de forma curta, nossa revisão de como Cabrera Infante recebeu Hemingway e de como sua obra aparece em duas produções artísticas latino-americanas poderia (talvez, possa ainda) funcionar como ponto de partida para uma investigação mais ampla sobre a recepção desse autor no contexto brasileiro. Tal proposta fica, evidentemente, para outro momento e outros pesquisadores. 


\section{Bibliografia}

ADORNO, Theodor \& HORKHEIMER, Max. Dialética do Esclarecimento. Rio de Janeiro: Jorge Zahar, 2006.

ADORNO, Theodor. Teoria Estética. Lisboa: Edições 70, 1982.

On jazz. Discourse. v. 12, n. 1, A Special issue on Music (Fall-Winter 1989-90), p. 45-69.

ARENDT, Hannah. As Origens do Totalitarismo: Imperialismo, Antissemitismo e Totalitarismo. São Paulo: Companhia das Letras, 1998.

AUERBACH, Erich. Mímesis: a representação da realidade na literatura ocidental. São Paulo: Perspectiva, 1971.

ASSIS, Machado de. Notícia da atual literatura brasileira: instinto de nacionalidade em Obras Completas, v. III. Rio de Janeiro: Nova Aguilar, 1994.

BAUDELAIRE, Charles. O Spleen de Paris: pequenos poemas em prosa. São Paulo: Hedra, 2009.

BAUDELAIRE, Charles. Sobre a modernidade. São Paulo: Paz e Terra, 1996.

BARRET, William. Irrational Man: a study in existential philosophy. Nova York: Anchor Books, 1997.

BEIGUELMAN, Giselle. A República de Hemingway: por quem os sinos dobram?, São Paulo: Perspectiva, 1993.

BENJAMIN, Walter. Passagens. Vários tradutores. Belo Horizonte: Editora UFMG, 2018.

BENJAMIN, Walter. Baudelaire a Modernidade. Belo Horizonte: Autêntica, 2015.

Magia e técnica, arte e politica: ensaios sobre literatura e história da cultura - Obras Escolhidas I, trad. Sergio Paulo Rouanet, São Paulo: Brasiliense, 1987.

BERMAN, Marshall. Tudo que é sólido se desmancha no ar: a aventura da modernidade, São Paulo: Companhia das Letras, 1986.

CLARK, T. J. A pintura da vida moderna: Paris na arte de Monet e seus seguidores. São Paulo: Companhia das Letras, 2004.

COSTA LIMA, Luiz. Mimesis: desafio ao pensamento. Rio de Janeiro: Civilização Brasileira, 2000.

DELEUZE, Gilles. Cinema 1 - a imagem-movimento. São Paulo: Editora 34, 
2018.

. Crítica e Clínica. São Paulo: Editora 34, 2011.

DELEUZE, Gilles \& GUATTARI, Félix. Kafka: por uma literatura menor. Belo Horizonte: Autêntica, 2017 1995. . Mil platôs: capitalismo e esquizofrenia - 5 v. São Paulo: Editora 34,

EVERDELL, William. Os Primeiros Modernos: as origens do pensamento do século XX. Rio de Janeiro: Record, 2001.

GAILlARD, Theodore L. Hemingway's Debt to Cézanne: New Perspectives. Twentieth Century Literature, v. 45, n. 1, 1999, p. 65-78.

GIDDENS, Anthony. As consequências da Modernidade. São Paulo: Editora Unesp, 1991.

GORTON-NESBITT, Rebecca J. The Aesthetics of Socialism: Cultural Polemics in 1960s Cuba. Oxford Art Journal, 2014, v. 37, n. 3 (2014), p. 265-283.

GUMBRECHT, Hans Ulrich. A Produção de Presença. Trad. Ana Isabel Soares. Rio de Janeiro: Contraponto/Editora PUC-Rio, 2010. 1926: vivendo no limite do tempo. Rio de Janeiro: Record, 1999.

GUTTMAN, Allen. Mechanized Doom: Ernest Hemingway and the Spanish Civil War. The Massachusetts Review, v. 1, n. 3 (Spring, 1960), p. 541-561.

HALLIDAY, E. M. Hemingway's Ambiguity: Symbolism and Irony. American Literature, v. 28, n. 1, 1956, p. 1-22.

HEMINGWAY, Ernest. Paris é uma festa. Rio de Janeiro: Bertrand Brasil, 2020. 2015. As Cartas de Ernest Hemingway: 1907-1922. São Paulo: Martins Fontes, . O Velho e O Mar. Rio de Janeiro: Bertrand Brasil, 2015. . O Sol Também Se Levanta. Rio de Janeiro: Bertrand Brasil, 2014. . Ter e Não Ter. Rio de Janeiro: Bertrand Brasil, 2014. . Por Quem os Sinos Dobram. Rio de Janeiro: Bertrand Brasil, 2013. . Adeus às Armas. Rio de Janeiro: Bertrand Brasil, 2013. . The Old Man and the Sea. Nova York: Scribner's Sons, 2003. 
. For Whom The Bell Tools. Nova York: Scribner's Sons, 2003.

. The Sun Also Rises. Nova York: Scribner Book Co., 2006.

. To Have and Have Not. Nova York: Scribner Book Co., 1996.

. The Short Stories. Nova York: Scribner's and Sons, 1995.

. Islands in the Stream. Nova York: Scribner's Sons, 1970.

. A farewell to arms. Nova York: Charles Scribner's, 1969.

HOBSBAWM, Eric. História social do jazz. São Paulo: Paz e Terra, 2009.

HOTCHNER, A. E. Papa Hemingway. Rio de Janeiro: Civilização Brasileira, 1967.

HUGHES, Stuart. Consciousness and Society: The Reorientation of European Social Thought, 1890-1930. New York: Alfred A. Knopf, 1958.

INFANTE, Guillermo Cabrera. Corpos Divinos. São Paulo: Companhia das Letras, 2016.

. Três Tristes Tigres. Rio de Janeiro: José Olympio, 2009.

JÜNGER, Ernst. Tempestades de Aço. São Paulo: Cosac \& Naify, 2013.

KOSELLECK, Reinhart. Futuro Passado: contribuição à semântica dos tempos históricos. Rio de Janeiro: Contraponto/Editora PUC-Rio, 2006.

LAWRENCE, D. H. Studies in Classic American Literature. Cambridge/Nova York: Cambridge University Press, 2003.

LEVIN, Harry. Observations on the Style of Ernest Hemingway, The Kenyon Review, v. 13, n. 4 (Autumn, 1951), p. 581-609.

MASTROBUNO, B. W. A Narrativa por meio da Ausência: análise de três contos de Ernest Hemingway. Dissertação de Mestrado. São Paulo: Faculdade de Filosofia, Letras e Ciências Humanas, Universidade de São Paulo, 2018.

OEHLER, Dolf. Quadros Parisienses: estética antiburguesa (1830-1848). São Paulo: Companhia das Letras, 1997.

PEAVLER, Terry. Guillermo Cabrera Infante's Debt to Ernest Hemingway. Hispania, May-Sep., 1979, v. 62, n. 3 (May-Sep., 1979), p. 289-296.

ROHY, Valerie. Hemingway, Literalism, and Transgender Reading. Twentieth Century Literature, v. 57, n. 2, 2011, p. 148-179.

ROSS, M. Bill Gorton, The Preacher in "The Sun Also Rises". Modern Fiction 
Studies, 18(4), 1972, p. 517-527.

SAFATLE, Vladimir. O Circuito dos Afetos: corpos políticos, desamparo e fim do indivíduo. Belo Horizonte: Autêntica, 2015.

SARTRE, Jean-Paul. Situações I. São Paulo: Cosac \& Naify, 2005.

SASSEN, Saskia. The Global City: New York. London, Tokyo. Princeton: Princeton University Press. 2001.

SIMMEL, Georg. As grandes cidades e a vida do Espírito. Trad. Leopoldo Waizbort. Rio de Janeiro: Revista Mana, 2007.

SANTIAGO, Silviano. Literatura nos Trópicos: ensaio sobre a dependência cultural. Rio de Janeiro: Rocco, 2000.

SASSON, Siefried. Memórias de um Oficial de Infantaria. São Paulo: Mundaréu, 2014.

SCHÖNPFLUG, Daniel. A Era do Cometa: A Guerra de 1918 e o limiar de um novo mundo. São Paulo: Todavia, 2019.

SCHWARZ, Roberto. Um mestre na periferia do capitalismo: Machado de Assis. São Paulo: Editora 34, 2012.

WATT, Ian. A Ascensão do Romance: estudos sobre Richardson, Defoe e Fielding. São Paulo: Companhia das Letras, 2010.

WATTS, Emily Stipes. Ernest Hemingway and the Arts. Champaing: University of Illinois Press, 1971.

WEBER, Max. Metodologia das Ciências Sociais. Campinas: Cortez/Editora Unicamp, 1992.

WHITE, Hayden. Trópicos do discurso: ensaios sobre a crítica da cultura. São Paulo: Edusp, 1994.

WHITE, Hayden. Meta-história: a imaginação histórica do século XIX. São Paulo: Edusp, 1992.

ZOLA, Émile. Germinal. Paris: Gallimard, 1999.

\section{Entrevistas}

The Kitchen Sisters Present - ep. 87: Guillermo Cabrera Infante: memories of a invented city. Disponível em: https://open.spotify.com/episode/7Egj841c81bYY1E c8lbYY1EPmgyr3O. Acesso em: 20 fev. 2021. 